Maurer School of Law: Indiana University

Digital Repository @ Maurer Law

1994

\title{
Legitimation and Statutory Interpretation: Conquest, Consent, and Community in Federal Indian Law
}

David C. Williams

Indiana University Maurer School of Law, dacwilli@indiana.edu

Follow this and additional works at: https://www.repository.law.indiana.edu/facpub

Part of the Indian and Aboriginal Law Commons, and the Legislation Commons

\section{Recommended Citation}

Williams, David C., "Legitimation and Statutory Interpretation: Conquest, Consent, and Community in Federal Indian Law" (1994). Articles by Maurer Faculty. 710.

https://www.repository.law.indiana.edu/facpub/710

This Article is brought to you for free and open access by the Faculty Scholarship at Digital Repository @ Maurer Law. It has been accepted for inclusion in Articles by Maurer Faculty by an authorized administrator of Digital Repository@Maurer Law. For more information, please contact rvaughan@indiana.edu. 


\section{LEGITIMATION AND STATUTORY INTERPRETATION: CONQUEST, CONSENT, AND COMMUNITY IN FEDERAL INDIAN LAW}

\section{David Williams*}

$\mathrm{E}$

VERY theory of statutory interpretation rests on an understanding of the legitimate basis of government and the separation of powers. To explain how courts should go about construing statutes, an interpretive theory inust delineate why those texts command devotion. That explanation, in turn, will lead the decisionmaker to propose a role for the legislature, a role for the courts, and a role for the bridge between thein-the statute itself. Consequently, courts engaging in the interpretation of federal Indian statutes inust consciously or unconsciously posit a view of the legitimate basis of Congress' power over the tribes. Reaching a view on that subject is not optional; every time the courts construe a statute regulating Indian affairs they inust in some way come to terms with the manner in which Congress acquired power over the contment and its indigenous peoples. Even if a judge concludes that she has no authority to deny Congress' power in this area, she must still decide how to interpret statutes based on the legitimacy of that power.

Unfortunately, in recent years the United States Supreme Court has offered hittle to explain the legitimacy of Congress' power over the tribes. Indeed, since the revisiomist 1960s, this subject has provoked considerable political unease in the country as a whole. Perhaps predictably, the Court's mode of interpreting Indian statutes has mirrored the public discourse in being highly inconsistent. While the justices sometimes profess to follow the will of Congress slavishly, regardless of the harm visited upon the tribes, at other tinnes they profess to interpret statutes so as to promote the tribes'

* Professor of Law, Indiana University-Bloomington. For their niany useful and kind suggestions on this draft, I would like to thank Kevin Brown, Daniel Conkle, Edwin Greenebaun, Lynne Henderson, William Popkin, John Scanlan, Robert Williams, and the participants in a facnlty seminar at Indiana University-Bloonington. As always, nyy first and last thanks go to Susan Williams. 
best interests despite considerable evidence of legislative intent to the contrary. Although the justices can be expected to grope in darkness as long as the Court's view of the legitimate basis of Congress' power remaims unexplored and unarticulated, the Court shows no signs of addressing this subject in the near future.

If a theory of Indian law interpretation inust necessarily begin by considering the nature of Congress' power over tribal affairs, then every Indian law case presents the most painful problem of federal Indian law: coming to terms with the sovereign presence of nonIndians in North America. For the inost part, the United States acquired sovereignty on this continent by violent conquest, defending the subjugation of imdigenous cultures by claiming racial and cultural superiority. In the late twentieth century, however, that discourse is no longer satisfying, as both American cultural norms and tribal conditions have changed. Without that prop, the basis of Congress' authority has begun to teeter. For reasons that I will later discuss, courts may feel unable or dismclined to repudiate Congress' authority wholesale. But as the basis for that authority has become obscure, so has the appropriate interpretive technique.

No longer able to rely on conquest to explain Congress' power over the tribes, courts inight seek to borrow from conventional explanations of Congress' general authority over non-Indian citizens. These conventional accounts, however, fail to justify Congress' authority over the tribes because of their unique historical relationship with the United States. Traditionally, the touchstone of political legitimacy in the United States has been procedural deinocracy based on a social contract. Laws are to be made and applied by a group of people gathered into a single political order for the purpose of goverming thenuselves. Conversely, laws are not to be inade extraterritorially, imposed by one group upon another. But federal Indian law, for all intents and purposes, is made by one people-the inainstreanı culture-for the purpose of regulating another-the tribes.

The mere fact that individual Indians possess the franchise is not enough to make them into a single people with the rest of the Umited States. Tribal Indians have never entered the social contract in either a historical sense (they never actually consented) or a metaphorical sense (nerger into the American polity is not a wliolesoine course for the tribes). For the same reason, more coin- 
munitarian defenses of legislative authority cannot ground Congress' jurisdiction over the tribes; even if the nation is a rich "community" in the necessary sense for most of us, it is not for tribal Indians. Their community is the tribe, the People, a legacy that they have never surrendered.

Doubts about the basis of Congress' power over the tribes spring not only from political theory but from federal Indian statutes themselves. Congress lias implicitly recognized that the tribes require their own separate pohtical orders, conceding that merger into the American polity would be unhealthy for thein. Under federal law, tribal governments are pre- and extraconstitutional territorial sovereigns that exercise aboriginal power over their own members and, to some extent, nonmembers. The federal government owes to these governments a special fiduciary obligation; the Supreme Court enforces treaties undertaken between tribes and the federal government on a government-to-government basis; and individuals possessing the special status of federally recognized Native Americans are defined by their genetic descent from those who inhabited this continent before the Europeans arrived. Indeed, the central interpretive issue in most innortant Indian law cases is low far Congress has acknowledged the tribal right to a separate pohtical order. But if separation is the interpretive issue in these cases, we cannot assume as part of our background interpretive method that the tribes are part of the United States political order in the same way that all otlier groups are. We need a different theory of interpretation, one sensitive to the unusual circumstances of the tribes.

Because they fail to address the tribes' umique histories, general theories of statutory interpretation offer little help in constructing a theory of interpretation for federal Indian statutes. In recent years, commentators have offered a range of highly sophisticated theories of statutory construction, most of which fairly explicitly state the view of government on which they rest and for which they argue. Althougli these conceptions of government authority vary radically, all share one feature: they assume that all Umited States citizens belong to the same pohtical order in precisely the same way. Tribal Indians, however, do not enjoy the same relationship witl the Umited States that non-Indian citizens do. In light of these circunistances, it would be mappropriate simply to assume that 
Congress' authority over the Indians flows from the same source as its authority over other United States citizens. Even by their own terms, these theories should be mappropriate for analyzing federal Indian statutes.

At present, then, no extant theory can justify Congress' authority over the tribes im the conventional procedural way, i.e., by tracing the origin of this authority to legitimate conquest, consent, or commumity. Without some account of Congress' legitimacy, however, the courts have no basis from which to derive an interpretive technique. In such circumstances, the courts could refuse to enforce congressional statutes altogether. Alternatively, by simply ignoring the conditions that distinguish the tribes, they could interpret Indian statutes exactly as they imterpret all other statutes. The first option is unlikely, the second unsavory.

In my view, there is an alternative already immanent but not express in the Court's practice, an alternative as unconventional as the rest of this aberrational area of law. If Congress' authority cannot be justified procedurally, it might nonetheless be justified substantively. In other words, while Congress may have no right to legislate for the Indians, perhaps it has created a scheme of Indian law that is substantively defensible as a inatter of inorality and justice. In accord with this view, courts should imterpret congressional statutes, when possible, to reach such a substantively correct result. At present, the courts already follow a version of this strategy by employing the canons of construction for Indian law: specifically, the Supreme Court claims to interpret federal statutes in the hight most favorable to the tribes. Although the Court often maintains that the canon serves as a guide to congressional imtent, at other times it asserts that the canon is rooted directly in considerations of equity.

Such an interpretive method may avoid the problein of Congress' procedural legitimacy, but it creates perhaps a larger difficulty in its stead: defining a "substantively correct" version of Indian law. That task is a problem no less for Congress in writing statutes than for the courts in interpreting them. Both must cope with the relatively new phenomenon of a post-colonial world. Congress has the power to regulate the tribes as if they were wholly within the American political system, but in fact they are not. In truth, Congress inust regulate and the Court must interpret 
across borders. Federal Indian law thus painfully presents the postmodern problem of intertextuality: how to communicate between two cultures that are not transparent to each other. One of the lessons of recent interpretive studies is that knowledge and value claims are, to a significant extent, culturally bounded: we can make judgments only froin within the framework of our cultural foundations. For that reason, no acultural, "objective" meta-ethic is possible, and hence none can be apphed by even an attentive, sympathetic legislature or judiciary.

In recent decades, a theory of the proper status of aborigmal populations in post-colonial settler states has begun nebulously to emerge. This theory contains two important substantive elements: first, it acknowledges the general, overarching sovereignty of the states, but second, it also insists upon the tribes' right to exist as distinct peoples exercising some degree of self-government. Significantly, the theory is rooted in tribal values, American democratic beliefs, and international principles. Rather than a meta-norin, it is perhaps the start of a practice that bridges the gulf between the state and the tribes, producing a culture created by Indians and non-Indians living and thinking together to the extent necessary to allow them to hive separately as well. It is this theory that may offer the basis for a substantive approach to interpreting federal Indian statutes.

Such an approach imght call for a structural change as well-the regular inclusion of tribal Indians in the interpretation of Indian statutes. The substantive theory calls on judges to imterpret statutes so as best to proinote the rights of tribes as peoples, and that task inevitably requires some contextual understanding of tribal values. But non-Indian federal judges are typically deeply situated in non-Indian legal culture; they will almost inevitably read statutes addressing Indian affairs with the concerns of mainstreain America in mind. In that sense, judicial interpretation of federal Indian statutes is still an imperial activity. As a substantive inatter, Congress has inediated the problein of intertextuality by giving tribal Indians some control over matters that touch directly on their hives. In the interpretation of Indian law, Congress could do the same by estabhishing a judicial forum staffed at least in part by tribal appointees.

Part I of this Article will advance the argument that any theory of interpretation involves a theory of legitimation. That cormec- 
tion holds in Indian law as in every other field, so that judges cannot help but inake some imphicit claim about the basis of Congress' authority over the Indians. Part II canvasses the concepts of legitimation associated with some of the inost prominent recent theories of interpretation and argues that they are inapposite to the situation of the Indians. Part III suggests that no democratic procedural justification of Congress' power is possible, and hence no theory of imterpretation can proceed from it. Given the impossibility of a procedural justification, the Part goes on to discuss the possibility of formulating a substantive theory to guide the interpretation of statutes. Part III concludes by calling for the estabhishment of a tribunal staffed by both federal and tribal officials to consider Indian law questions.

\section{INTERPRETATION AND LEGITIMATION}

\section{A. The Connection Between Interpretation and Legitimation}

Every theory of statutory construction explaining how and why judges interpret statutes posits a theory of the separation of powers, describimg the proper role of the courts and of Congress and the relationship between the two. To establish a method for interpreting statutes, a judge inust determine what political functions the judiciary and statutes themselves are supposed to serve. For example, in perhaps the most common formulation, judges engaged in statutory construction are urged to consult ouly the text and perhaps the legislative history of the statute, making sure not to mject any personal sentiments or values into the interpretation process. The justification for himiting the inquiry to indices of legislative intent is political: judges should function as the legislature's passive agents because that body is the most truly dernocratic branch in a polity that prizes democracy above all. ${ }^{1}$ If, by contrast, one believed that natural law were inore important than democracy, and that judges had special access to natural law's dictates,

1 See, e.g., William N. Eskridge, Jr., The New Textualism, 37 UCLA L. Rev. 621, 626-32 (1990); William D. Popkin, The Collaborative Model of Statutory Interpretation, 61 S. Cal. L. Rev. 541, 547 (1988); Cass R. Sunstein, Interpreting Statutes in the Regulatory State, 103 Harv. L. Rev. 405, 415 (1989). 
one might wish to allow judges greater freedom in their interpretive technique. ${ }^{2}$

In other words, judges camiot be "passive" or "neutral" in choosing an interpretive theory, even if the particular theory selected requires that judges thereafter be "passive" or "neutral." 3 Instead, courts must refer to some potentially controversial political theory to ground their mode of construction. ${ }^{4}$ For any particular imterpretive theory to be persuasive, then, its associated theory of government must also be persuasive, both in general and in the particular context to be addressed-for our purposes, Indian law. It must rest on an understandimg of the legislature and the courts that is not only plausible but also normatively appealing. For example, the courts-as-passive-agents approach would fail to convince if it could be shown either that the legislature is not democratic or that majoritarian democracy is not of paramount concern. ${ }^{5}$

This connection between interpretation and legitimation holds no less true for federal statutes regulating Indian concerns. Whenever judges imterpret such statutes, they must acknowledge some theory-even if only tacit-that explains why Congress possesses the authority to direct Indian affairs. It is important to stress that judges must identify some such theory of legitimation, because in the past courts have deferred to congressional plenary power over the tribes without any inquiry into the legitimacy of that power. For years, the Supreme Court has professed its unquestioning adherence to Congress' will in this field; ${ }^{6}$ for a number of decades it even described Congress' Indian affairs power as falling under

2 See, e.g., Michael J. Perry, The Constitution, the Courts, and Human Rights: An Inquiry into the Legitimacy of Constitutional Pohcymaking by the Judiciary 110-13 (1982).

3 See Williain D. Popkin, Law-Making Responsibihty and Statutory Interpretation, 68 Ind. L.J. 865 (1993).

4 See Ronald Dworkin, Law's Empire 258-60 (1986); Sunstein, supra note 1, at 412. Theoretically, of course, judges could select their interpretive strategy randomly. But if they seek to give ineaning to the process of interpreting statutes, they must decide what a statute is and why it matters-questions traditionally grouped under the heading "political theory." I do not mean to use that phrase in a restrictive way; in particular, I do not mean to refer only to foundationalist, propositional, or analytical theory.

5 See, e.g., William D. Popkin, An "Internal" Critique of Justice Scalia's Theory of Statutory Interpretation, 76 Minn. L. Rev. 1133, 1167-73 (1992).

6 See Philip P. Frickey, Congressional Intent, Practical Reasoming, and the Dynamic Nature of Federal Indian Law, 78 Cal. L. Rev. 1137, 1139-40 (1990). 
the political question doctrine. ${ }^{7}$ It is thus the case tliat the Court is not accustomed to questioning Congress' power over the tribes; rather than confrontimg the issue squarely, the justices tend to flinch before that task, even when review of constitutional nratters is involved. ${ }^{8}$

As a practical matter, it niay be too late in the day-or too early-to urge the Suprenie Court to eliminate or restrict the plenary power doctrine, ${ }^{9}$ although nrany have sought to do so. ${ }^{10}$ But even if the courts accept the fact of Congress' plenary power, that acceptance does not resolve the interpretive dilemma, for although the courts may take it as a given that Indian statutes are presumptively valid, they must still develop an understanding of the nature of Congress' authority in order to know how to interpret its nuandates. To borrow a military metaphor from Richard Posner, as modified by Daniel Farber and Philip Frickey, assume that judges are like platoon commanders under orders from their superiors, the legislature. Those platoon commanders acknowledge without question the right of their superiors to coniniand. But to understand the orders given, the commanders must understand the nature, purpose, and function of the military organization. The problem of justification, im short, may tenıporarily hide behind the cloud of plenary power, but it reemerges at the interpretive stage. ${ }^{11}$

7 For an authoritative review of the history of the plenary power doctrine and the political question doctrine, see Nell J. Newton, Federal Power over Indians: Its Sources, Scope, and Limitations, 132 U. Pa. L. Rev. 195 (1984).

8 Indeed, even on the level of constitutional analysis, the Court lias tended to review Congress' actions witl extreme deference. See, e.g., Washington v. Confederated Bands \& Tribes of the Yakima Indian Nation, 439 U.S. 463, 502 (1979); Ralpl W. Johnson \& E. Susan Crystal, Indians and Equal Protection, 54 Wash. L. Rev. 587, 588 (1979).

9 As Milner Ball has explained, "The Court has never held a congressional exercise of power over Indian tribes to be illegal, and there is no reason to think it ever will." Milner S. Ball, Constitution, Court, Indian Tribes, 1987 Am. B. Found. Res. J. 1, 12.

10 See Robert N. Clinton, Isolated in Their Own Country: A Defense of Federal Protection of Indian Autonomy and Self-Government, 33 Stan. L. Rev. 979 (1981); Newton, supra note 7; Robert A. Williams, Jr., The Algebra of Federal Indian Law: The Hard Trail of Decolonizing and Americanizing the White Man's Indian Jurisprudence, 1986 Wis. L. Rev. 219 [heremafter Williams, Algebra]. My own efforts to that end are contained in David C. Williams, The Borders of the Equal Protection Clause: Indians as Peoples, 38 UCLA L. Rev. 759 (1991) [hereinafter Williams, Borders] and David Williams, Sometimes Suspect: A Response to Professor Goldberg-Ambrose, 39 UCLA L. Rev. 191 (1991).

11 See Daniel A. Farber \& Philip P. Frickey, Legislative Intent and Public Choice, 74 Va. L. Rev. $423,461-65$ (1988). 
The doctrine of plenary power has worn various guises, but to illustrate this claim, I will focus on two: the oldest and the most contemporary. In the early years of the repubhic, Chief Justice John Marshall propounded a proto-version of the plenary power doctrine based on institutional necessity rooted in the origin of non-Indian sovereignty over the continent. ${ }^{12}$ Under the doctrine of discovery, the sovereign European nations agreed that whichever nation should first make contact with a portion of the New World would thereafter have an exclusive right to deal with the natives inhabiting that area. ${ }^{13}$ Under this principle, discovery reduced Indian title m only one way: it barred the tribes from transferring full title without obtaining the discovering sovereign's consent. Even after discovery, the tribes retained a right of occupancy. ${ }^{14}$ However, Great Britain and its legal heir, the United States, also claimed rights beyond those given by the discovery doctrine. In particular, they claimed the unqualified power to extniguish Indian title by purchase or conquest:15 "All our institutions recognise the absolute title of the crown, subject only to the Indian right of occupancy, and recoginise the absolute title of the crown to extinguish that right."16

Marshall was unconifortable with this doctrine of plenary. power. ${ }^{17} \mathrm{He}$ openly brooded about whether acquisition of the con-

12 Johnson v. M'Intosh, 21 U.S. (8 Wheat.) 543 (1823). Readings of Johnson other than the one offered here are possible. In particular, I characterize the opinion as accepting conquest and a plenary power arising from conquest. Others have interpreted the opinion to be more restrictive of Congress' powers. See, e.g., Ball, supra note 9, at 23-29. But I have interpreted the opinion in this way for a reason: even if Johnson recognizes a plenary power gronnded in conquest, that recognition still does not explain how to interpret statutes.

13 Johnson, 21 U.S. (8 Wheat.) at 573.

14 Id. at 573-74.

15 Id. at 587.

16 Id. at 588.

17 Johnson did not establish a plenary power in so many words, but such a power seems fairly inplicit in the decision's reasoning. In Johnson, the Court recognized the conqueror's right to drive the tribes from their land and-if possible, given the very different cultures involved-to assimilate the tribes into the American polity. Id. at 589. In a later case, Marshall characterized Congress' constitutional power as plenary only over commercial relations with the tribes, rather than over their internal affairs:

[The Constitution] confers on congress the powers of war and peace; of nuaking treaties, and of regulating commerce with foreign nations, and aniong the several states, and with the Indian tribes. These powers comprehend all that is required for 
tinent by conquest could be morally justified. ${ }^{18}$ Yet despite his personal concerns, Marshall ultimately asserted that the Supreme Court could not question the legitimacy of conquest because to do so would be to question the legitimacy of the federal government's claim to the territorial United States:

However extravagant the pretension of converting the discovery of an inhabited country into conquest may appear; if the principle has been asserted in the first instance, and afterwards sustained; if a country has been acquired and held under it; if the property of the great mass of the community originates in it, it becomes the law of the land, and cannot be questioned. ... However this restriction inay be opposed to natural right, and to the usages of civilized nations, yet, if it be indispensable to that system under which the country has been settled, and be adapted to the actual condition of the two people, it niay, perhaps, be supported by reason, and certainly cannot be rejected by Courts of justice. ${ }^{19}$

Marshall here is making an important point about the connection between interpretation and legitimation. As a Supreme Court justice, his essential function is to interpret and apply federal law. If all of federal law is illegitimate, because Congress' authority over the continent is illegitimate, then Chief Justice Marshall has no function. Speaking from the Suprenre Court building, through the U.S. Reports, Marshall nray not pronounce the United States illegitimate, because to do so would render illegitimate the building, the Reports, Marshall himself ex officio, and even the pronouncement of illegitimacy itself. Consequently, he inust refuse to act upon the notion that the federal government had no right to exist

the regulation of our intercourse with the Indians. They are not limited by any restrictions on their free actions.

Worcester v. Georgia, 31 U.S. (6 Pet.) 515, 559 (1832). But Marshall's argument in Johnson seems to be extraconstitutional: in the nature of things, courts of the conqueror camiot deny the rights brought by conquest, at least if that conquest is fundamental to the conquering nation's legitimacy. Johnson, 21 U.S. (8 Wheat.) at 591. Thus, Johnson (and the "nature of things") and Worcester (and the Constitution) suggest different analyses of congressional attempts to intervene into a tribe's internal affairs by way of conquest.

18 Johnson, 21 U.S. (8 Wheat.) at 588-89, 591-92. Marshall explained that the right of conquest would prevail "[h]owever [divesting the Indians of title to their lands] may be opposed to natural right, and to the usages of civilized nations," and "[h]owever extravagant the pretension of converting the discovery of an inhabited country into conquest may appear." Id. at 591.

19 Id. at 591-92. 
because the "great mass" of its territory was acquired by conquest. As an interpreter of the law of nature, some "private citizen" might very well reach that conclusion, but a Supreme Court justice may not do so: "Conquest gives a title which the Courts of the conqueror cannot deny, whatever the private and speculative opimions of individuals inay be, respecting the original justice of the claim which has been successfully asserted." 20 For such an official, the Founding Sword supphes its own vahdation.

According to Marshall, then, for institutional reasons the Court must accept the brute fact that conquest has inade legitmiate Congress' jurisdiction over Indian policy. But accepting the fact of that power does not prevent a court froin questioning whether its exercise can be justified, as Marshall plainly did. And those doubts may resurface when a judge turns to interpreting statutes, just as they did for Marshall. Indeed, in one breath, Marshall acknowledged the right of conquest, but in the next he created the canons of construction that oftentimes limit that power, guidelines which seem to have grown directly out of his concerns about the legitimacy of federal power over the Indians. In Worcester $v$. Georgia, ${ }^{21}$ Marshall inaugurated the judicial tradition of reading ambiguous federal statutes and treaties to protect tribal self-determination. In so doing, he likened the course of legal relations between the federal government and the Cherokees to bargaining between equal parties; accordingly, he interpreted the relevant treaties so as to preserve those rights most important to the Cherokees. ${ }^{22}$ Clearly, consent coinported more closely with Marshall's political convictions than did conquest as a basis for Congress' power, providing him with a paradigm to use $m$ constructing an interpretive strategy.

In Johnson v. M'Intosh, ${ }^{23}$ Marshall inade only the crude point that he could not repudiate the power that conquest brings. That observation merely sets an outside himit by which those interpreting federal statutes and treaties must abide: the Court may not deny Congress' power over Indian affairs. Within tliat perimeter, Johnson fails to provide guidance to courts engaged im the dehcate task of giving legislative and executive mandates concrete meaning.

20 Id. at 588.

2131 U.S. (6 Pet.) 515 (1832).

22 Id. at 553-54; see Frickey, supra note 6, at 1177, 1224-30.

2321 U.S. (8 Wheat.) 543 (1823). 
To achieve that purpose, Marshall in Worcester had to set forth a more detailed argument exphicitly addressing how Congress' power was to be justified. There is nothing mevitable about the particular argument that Marshall advanced in Worcester. He could just as easily-indeed, given his time, more easily-have concluded that Congress' power was justified by the natural superiority of industrial/agricultural cultures over noinadic ones. ${ }^{24}$ The point is that he needed some such theory to guide him in construing the statute; an assertion of raw power only establishes the existence of that power, not a method for interpreting expressions of it.

Today the Court relies upon an entirely different set of factors to explain the basis of Congress' plenary power. Most often the Court asserts that Congress' plenary power arises from various constitutional grants of legislative authority, including the power to regulate commerce with the Indian tribes, the treaty power, the war power, the federal property power, and the power to regulate the territories. ${ }^{25}$ Because the Court no longer considers it a political question, the contemporary plenary power over Indian affairs is limited to soine extent by the Bill of Rights and the Fourteenth Amendment, just as is Congress' plenary power over interstate commerce. ${ }^{26}$ Some commentators would go further, arguing persuasively that the Constitution grants plenary power not over all Indian affairs but only over Indian commerce, giving Congress no authority to regulate matters internal to the tribes. ${ }^{27}$ Still others reject all government participation in Indian affairs, arguing that constitutional authority over the tribes is morally illegitimate under any circumstances. ${ }^{28}$

My present contention is more modest: even if the Court continues to hold that the Constitution grants Congress broad power over the tribes, that conclusion does not resolve how courts should

24 Many Indian groups were in fact sedentary agriculturalists, but non-Indians found little difficulty in overlooking that fact. See William Cronon, Clianges in the Land: Indians, Colonists, and the Ecology of New England 38-45 (1983); Brian W. Dippie, The Vanishing American: White Attitudes and U.S. Indian Policy 50-51, 108 (1982); R. Douglas Hurt, Indian Agriculture in America: Prelistory to the Present (1987).

25 See, e.g., Cotton Petroleum Corp. v. New Mexico, 490 U.S. 163, 192 (1989); United States v. Wheeler, 435 U.S. 313, 323 (1978).

26 See United States v. Sioux Nation of Indians, 448 U.S. 371, 413 (1980).

27 See Clinton, supra note 10 , at $999-1000$.

28 Williams, Algebra, supra note 10. 
interpret federal Indian statutes. Despite important arguments to the contrary, the Court imght still assume that it institutionally disabled from denying a constitutional grant of authority to Congress over Indian affairs because the Constitution also created the Court itself. ${ }^{29}$ In the justices' minds, then, the Constitution might occupy the same role that Marshall gave conquest-a given that carmot be questioned. But while the Constitution may provide Congress with legislative authority over Indian affairs, it leaves unanswered how such statutes are to be interpreted. ${ }^{30}$ To answer that question, the Court must examine the nature, origin, and justification of Congress' power over the Indian tribes. ${ }^{31}$

In summary, even if the courts accept congressional power as a brute fact imposed on them by the Constitution or imstitutional necessity, they inust still seek a reason justifying that power $\mathrm{m}$ order to provide themselves with a lodestar to guide interpretation. The rhetoric of plenary power, im other words, does not free the Court froin the worrisoine need to reflect upon the basis of Congress' power over the Indians; that anxiety arises every time the Court puzzles over a statute. I do not mean to suggest that all courts are consciously plagued with such anxiety; indeed, judges may engage im quite elaborate ploys to evade recognizing such disquiet. But even if a court decides to imterpret federal Indian statutes in the same way that it interprets all other statutes, it has implicitly made a claim: specifically, that the nature and basis of Congress' authority over the Indians is not substantially different from the nature and basis of Congress' power over other citizens. As I will argue in the next Section, that claim is difficult to sustain because the tribes do not stand in the saine relation to the American pohtical order as do other citizens of the United States.

29 That assumption does not, of course, tell the Court how broad that grant of power is. The Court might conclude, for example, that the Constitution accords Congress only a highly restricted power over the tribes.

30 See Popkin, supra note 5, at 1161-62.

31 This distimction-between the existence of a given power and the proper mode of interpreting statutes passed under that power-is implicit in other areas of statutory interpretation. Recently, Cass Sunstein has argued that all statutory interpretation requires the judge to select background interpretive norms. Importantly, even when the courts concede Congress' constitutional power to pass the statute in question, that concession alone does not provide the interpretive technique. Instead, the courts must choose appropriate background norms by adverting to "good substantive and institutional arguments ... on their behalf." Sunstein, supra note 1 , at 461 . 
I call this nagging worry about the legitimacy of Congress' power "conqueror's anxiety."32 The illegitimacy of Congress' power over the tribes is the subject of a rich literature. ${ }^{33}$ Although I cannot recapitulate that scholarship in all of its complexity, I offer below a synoptic argument demonstrating that real doubt exists as to whether Congress' authority over the tribes can be justified at all.

\section{B. The Conqueror's Anxiety: Conquest and Consent}

\section{Conquest}

Conqueror's anxiety steins from the fact that much of Congress' authority over this contment was secured and maintamed by force. Originally, that fact caused the conquerors little concern because of the widespread behef that the conquest was justified. At the time, many asserted that the conquest benefitted the Indians by bringing civilization, Christiamity, and/or a better standard of hiving to the tribal "savages." Equally, if not more importantly, the conquest made land available to non-Indians who would use the land productively rather than leave it a "wilderness." 34 Even those favorably mchined towards the tribes did not generally recognize the Indians' sovereign right to the land, maintaining that the best course was to integrate the Indians into the general population as quickly and coinpletely as possible. ${ }^{35}$ The Indians would then

32 Professors Eskridge and Frickey have argued that the Court generally suffers from a "counter-majoritarian anxiety": conscious of their unelected status, the Justices are "reluctan[t] to admit that [the Court] - and not the Congress-makes the decision about statutory meaning in a difficult case." William N. Eskridge, Jr. \& Philip P. Frickey, Statutory Interpretation as Practical Reasoining, 42 Stan. L. Rev. 321,378 (1990). That anxiety causes the Court rhetorically but speciously to pledge passive obedience to Congress. Another anxiety, in my view, is at work in Indian law: even if real passivity were possible in difficult cases, Congress' authority over the tribes-derived as it is from conquest-may not warrant such devotion.

33 See, e.g., Russel L. Barsh \& James Y. Henderson, The Road: Indian Tribes and Political Liberty (1980); Robert A. Williams, Jr., The American Indian in Western Legal Thought: The Discourses of Conquest (1990); Ball, supra note 9.

34 See Johnson, 21 U.S. (8 Wheat.) at 590; United States v. Kagama, 118 U.S. 375, 380-84 (1886); Dippie, supra note 24; Richard Drinnou, Facing West: The Metaphysics of IndianHating and Empire-Building (1980); Roy H. Pearce, Savagism and Civilization: A Study of the Indian and the American Mind (rev. ed. 1965); Richard Slotkin, Regeneration Through Violence: The Mythology of the Anierican Frontier, 1600-1860, at 194-205 (1973); Williams, supra note 33 ; Ball, supra note 9 , at 8 .

35 Johnson, 21 U.S. (8 Wheat.) at 589-90; Newton, supra note 7, at 206. See generally Frederick E. Hoxie, A Final Promise: The Campaign to Assimilate the Indians, 1880-1920 
stand in the saine relationship to the United States as did every other citizen. Indeed, ideally they would be indistinguishable except for shight physical differences and perhaps some cultural variation coniparable to that exhibited by other ethnic groups. Under this assimilative inodel, interpreting federal Indian statutes would be unproblematic: they would be treated in the saine manner as any other statute.

Tribal Indians have not, however, been fully integrated into the dominant political order. They retain a limited right to self-determination and territorial sovereignty. More significantly, the ideology of conquest-with its attendant racism and cultural imperiahism-is no longer widely shared. While a few Americans may beheve that Indians are still emerging froin savagery, that the conquest was just because it substituted a superior for an inferior civilization, and that the best course is the wholesale assimilation of the tribes, such views today have few public defenders. ${ }^{36}$ For some years, the official policy of Congress ${ }^{37}$ and the President ${ }^{38}$ has been to promote rights of tribal self-determination, and the Supreme Court has echoed this view when interpreting legislative and executive action in this area. ${ }^{39}$ Accordingly, some theory of interpretation/legitimation other than conquest in the name of progress is necessary. ${ }^{40}$

(1984); Americanizing the American Indians: Writings by the "Friends of the Indian" 1880 1900 (Francis P. Prucha ed., 1973).

36 It is possible that such views inay be more widespread in popular culture-as opposed to the liberal legal culture of which Congress and the courts are members. Any theory of interpretation of federal statutes, however, must resonate within legal culture since statutory interpretation takes place within that culture.

37 See, e.g., Felix S. Cohen, Handbook of Federal Indian Law 180-207 (1982 ed.).

3s See, e.g., Statement on Indian Policy (Jan. 24, 1983), reprinted in 1 Public Papers of the Presidents of the United States: Ronald Reagan, 1983, at 96-100 (1984); Message from the President of the United States Transmitting Recommendations for Indian Policy, H.R. Doc. No. 363, 91st Cong., 2d Sess. (1970) (Richard Nixon) [hereinafter Nixon Message].

39 See, e.g., California v. Cabazon Band of Mission Indians, 480 U.S. 202, 216-19 (1987).

40 I take this view as a given throughout this Article, because I know of no commentators who seriously argue that conquest is a legitinate means of policy towards the tribes. Milner Ball offers a fascinating but importantly different "origin story" that might be pressed imto service: intruders created the state by conquering natives and then coercing them into a compact that treated all alike. This story thus combines conquest and consent. As Ball points out, however, this story is inappropriate to describe Congress' authority over the tribes, because while fratricide occurred, the later stage of fraternity never did. See Ball, supra note 9 , at 7-10. 


\section{Formal Consent}

The traditional alternative to power arising from conquest is power derived from consent. The narrative portraying conquestas-inoral-war offers an explanation of Congress' power that is specific to Indian affairs; power-from-consent, by contrast, is the conventional account offered to explain Congress' power over all Umited States citizens. ${ }^{41}$ Popular consent to government occurs at two stages. First, a supermajority of the people consent to a Constitution providing the basic framework for the Nation. ${ }^{42}$ Periodically thereafter, the citizens of the Umited States, in accord with the Constitution, vote individually to elect representatives. ${ }^{43}$ Government is legitimate, in short, because it is democratic, both im its creation and its operation.

This theory of legitimation by consent grounds what inay be the most familiar theory of interpretation-the legislative intent model. The legislature, this account maintaims, was chosen to make law because it is the most democratic branch and hence the most accountable to the people. Legislative intent, then, reflects and gives voice to the popular will as expressed in statutory form. Judges, who are generally not pohtically accountable, must thus enforce these statutes in accord with the "legislative intent" to the extent that they are able to discern it. Government, in this scheme, is an elaborate systein of agency based on popular consent: the legislature is the agent of the people, and the judges are the agents of the legislature.

Neither this theory of legitimation by consent, nor its associated intentionahist mode of interpretation, are apposite to the tribes' umque circumstances. Today, American Indians are citizens with full voting rights. As inany have noted, however, American Indians were not among the "People" who consented to the United States Constitution. Nor did most Indians-as individuals or as

41 See, e.g., Barsh \& Henderson, supra note 33, at 15; John H. Ely, Democracy and Distrust: A Theory of Judicial Review 5-7 (1980); Richard C. Simopoh, The Foundations of American Citizenship: Liberalism, the Constitution, and Civic Virtue 34 (1992); see also John Rawls, A Theory of Justice 11-17 (1971) (defending social contract theory for modern Americans).

42 M'Culloch v. Maryland, 17 U.S. (4 Wheat.) 316, 402-05 (1819).

43 See Barsh \& Henderson, supra note 33, at 16; Richard B. Collins, Indian Consent to American Government, 31 Ariz. L. Rev. 365, 370-71 (1989). 
tribes-ever formally consent to enter the American body politic at any later stage. ${ }^{44}$ To the contrary, many tribes secured treaties that guaranteed them some imdependence from the United States "as long as grass grows or water runs." Although these treaties also surrendered some limited sovereignty, that surrender was limited to the particular treaty signatories and to the discrete quantum of sovereignty surrendered. While this history might thus support a congressional power created and cabimed by individual treaties, it cannot ground a general power in Congress to regulate all Indian affairs. ${ }^{45}$ Many of these treaties, moreover, were in no sense consensual: the United States instead procured them by fraud, manipulation, or violence. ${ }^{46}$ Finally, although most Indians became citizens by unilateral decree of Congress in $1924,{ }^{47}$ some still refuse to accept the authority of the United States and deny that they are citizens of what they regard as a foreign and imperial power. ${ }^{48}$ In short, as one commentator has compellingly argued, the annexation of tribes to the federal umion occurred through a rhetoric not of Lockean consent but of colonial expansion. ${ }^{49}$ Simply put, the tribes never formally agreed to become a part of the federal union.

\section{Constructed Consent}

On the other hand, formal consent may not be necessary to justify Congress' authority over the tribes even within a consent-based model of government. The social contract, it is sometimes argued, is not an actual historical event at all, but a heuristic construct: if presented with the contract's terms, reasonable persons concerned with preserving their individual freedom would have adopted them. That construct thus encapsulates the central hiberal virtues

44 See Barsh \& Henderson, supra note 33, at vii, 285; Robert N. Clinton, Tribal Courts and the Federal Union, 26 Willamette L. Rev. 841, 845-54 (1990); Collins, supra note 43, at 371; Frank Pommershein, Liberation, Dreams, and Hard Work: An Essay on Tribal Court Jurisprudence, 1992 Wis. L. Rev. 411, 417-20.

45 See Barsh \& Henderson, supra note 33, at 270-82; Ball, supra note 9, at 21-22.

46 See Joseph W. Singer, Sovereignty and Property, 86 Nw. U. L. Rev. 1, 14-17 (1991).

47 See Act of June 2, 1924, ch. 233, 43 Stat. 253, repealed by Act of June 27, 1952, ch. 477, 66 Stat. 279, 280; Clinton, supra note 44, at 854 . Some Indian groups had already become citizens under earlier statutes. See, e.g., Act of Mar. 3, 1865, cl. 127, 13 Stat. 541, 562.

48 See Barsh \& Henderson, supra note 33, at 96; Ball, supra note 9, at 11.

49 See Clinton, supra note 44 , at $854-68$. 
of liberty, individualisin, and the rational pursuit of self-interest. ${ }^{50}$ Thus, the defense of American government is not tliat individual citizens actually consented to the contract, but that the contract construct promotes individual liberty in a rational manner for rational persons. Historical refusal to sign on the dotted line is no claim of immunity against the authority of the best (liberal) form of government.

It is critical, lowever, to recognize how modern liberal thinkers use this social contract-as-construct and the suppositions underlying it. Importantly, the model presumes the existence of an extant, liberal state and addresses concerns internal to that state. It explains liow the state-consistent witl a consent-based theory of government-can exercise jurisdiction over citizens within its borders even if they did not individually consent. The model then limits the exercise of that power, requiring states to respect the contract's terms. But the model does not address tlie delineation of boundaries at all. It simply presupposes their existence and then argues that all citizens witlin these boundaries are vicarious signatories to the construct. ${ }^{51}$ To use the social contract-as-construct approacli to resolve boundary disputes is radically to misuse it. Liberalism cannot provide the grounds for imperialisin.

To illustrate, suppose tliat England and Wales are different countries. Next, imagine tliat England's constitution best encapsulates the social contract tliat "reasonable" persons would adopt, so that England's constitution best protects autonomy and reason. Let us also assume that Wales' constitution does not encapsulate the social contract or does so poorly. That assumption demonstrates for social contractarians only that the Englisl government exercises legitimate sovereignty over Englislı citizens, despite the absence of formal individual consent. It does not deinonstrate that the Englislı can exercise sovereignty over tlie Welslı snnply because they possess a constitutional form that more closely approximates

so See Raymond Polin, John Locke's Conception of Freedom, in John Locke: Problems and Perspectives: A Collection of New Essays 1, 10-13 (John W. Yolton ed., 1969); Michael J. Sandel, Liberalism and the Limits of Justice 105-06 (1982); Simopoli, supra note 41, at 6465, 133; David C. Williams \& Susan H. Williams, Volitionalism and Religious Liberty, 76 Cornell L. Rev. 769, 857 n.317 (1991).

51 See Rawls, supra note 41, at 8; Will Kymlicka, Liberalism, Community and Culture 177-78, 206-16 (1991); Joseph H. Carens, Democracy and Respect for Difference: The Case of Fiji, 25 U. Mich. J.L. Reform 547, 581 (1992). 
the Ideal Social Contract. If it did, the Englisl could assert jurisdiction not only over the Welsh but over all other countries witl "inferior" constitutions-all without any formal consent. Sucl a thesis would destroy even minimal respect for international boundaries. England did, of course, assert sovereignty over mucli of the "uncivilized" world, but it did so eitler under the rlıetoric of empire or formal consent througli treaty.

The work of John Rawls illustrates the importance of recognizing that social contract liberalism does not mandate imperialism. When his magisterial Theory of Justice ${ }^{52}$ first appeared, some contended that Rawls intended his "original position"-a social contract-construct-to offer a legitimate basis for government that transcended time and place. ${ }^{53}$ Later, Rawls explained that his political theory of justice is best suited to Western constitutional democracies, because the cultures of those countries already embrace liberal procedural justice. ${ }^{54} \mathrm{He}$ was not suggesting that his theory would resonate in otlier cultures, mucli less that otlier cultures must accede to his theory. ${ }^{55}$

Only within a stable state with stable borders, then, can we dispense with a sliowing of formal consent. When offered to resolve border disputes, if the liberal concern witli self-determination is to have any meaning, consent must be formal, historical, and self-conscious. By all adimission, the tribes were originally outside of Congress' jurisdiction, and they never formally consented to Congress' plenary sovereignty.

\section{Ascribed Consent}

For similar reasons, it would be unreasonable to ascribe silent or tacit consent to Native Americans. Like the tribes, otler groups lad citizenship conferred on them by Congress even thougl they never formally consented to its bestowal. For example, freed black slaves, women, and poor white males were also unrepresented at the great metaphorical Constitutional Assembly, and Congress

\footnotetext{
52 Rawls, supra note 41.

53 See, e.g., Sandel, supra note 50, at 105.

54 See John Rawls, The Idea of an Overlapping Consensus, 7 Oxford J. Legal Stud. 1, 3-5 (1987).

55 Cf. Sinopoli, supra note 41, at 23 (arguing that liberal democracy is not appropriate in all times and places).
} 
later accorded citizenship and/or enfranchisement to these persons without seeking each individual's consent. ${ }^{56}$ Within the framework of classical liberalism, an ascription of tacit consent to anyone provides a fairly weak basis for legitimating governmental authority, but it is nonetheless a conventional tactic. ${ }^{57}$ But while it might be customary and not altogether implausible to ascribe consent to these other groups, it is not reasonable to argue that the Indians so acquiesced. Although there is a good chance that most free slaves, women, and poor white males would have consented to Congress' conferring citizenship upon them if asked, there is very hittle likelihood that most tribal Indians would have done so.

In this regard, tribal Indians differ from other groups in two important respects: their background prior to Congress' conferral of citizenship and the results ensuing from having citizenship conferred upon them. Women, blacks, and poor white males liad grown up within the territorial United States without ever having known a separate nation of their own here. Moreover, some claim that by failing to emigrate, women and poor white males revealed their tacit consent to the social contract. ${ }^{58}$ Fimally, representatives deputized by these groups petitioned forcefully for full inclusion, making a presuunption of consent reasonable..$^{59}$ American Indians, by contrast, did not grow up within the territorial United Statesor at least they did not regard it as U.S. territory even if mternational law did so. Moreover, their failure to emigrate could not be taken to indicate tacit consent to join the United States' body politic because they did not believe that their land was part of the United States. Indeed, the failure to emigrate reflected their deternination to resist mclusion, to remain on tribal lands and not be

56 See U.S. Const. amends. XIV, XIX. Indeed, during the debates over the Fourteenth Amendment, at least one Senator worried-perhaps disingenuously-about the propriety of giving citizenship to anyone who might not want it, but he was roundly ignored. See Cong. Globe, 39th Cong., 1st Sess. 526 (1866) (remarks of Sen. Guthrie).

57 See Dworkin, supra note 4, at 192-93; Sinopoli, supra note 41, at 108-09.

58 This argument is notoriously weak but is nevertheless very common. See Dworkin, supra note 4, at 192-93. In any event, the point is not that failure to emigrate establishes consent, but that even if it did, the Indians' failure to emigrate did not indicate consent because they did not believe that their land was part of the United States.

59 See, e.g., Olive Banks, Faces of Feminism: A Study of Feminism as a Social Movement 118-50 (1981); Eric Foner, Reconstruction: America's Unfinished Revolution 1863-1877, at 281-91 (1988); Robert H. Wiebe, The Opening of American Society: From Adoption of the Constitution to the Eve of Disunion 154-56 (1984). 
driven off. ${ }^{60}$ Finally, American Indians did not petition to become meinbers of the federal union; indeed, almost universally they resisted it, sometimes by words, but more often by force of arms. ${ }^{61}$

American Indians also experienced inclusion differently than did other origmally excluded groups, at least as their experiences are conventionally described. Upon inclusion, woinen, blacks, and poor white males becaine entitled to constitutional rights, including the right to vote. According to liberal democratic theory, these gifts were sufficient to ensure that these individuals could obtain justice within their hoineland, a constitutional deniocracy. They now stood before the government on the sanie footmg as all other citizens, entitled to command their representatives through the system of democratic accountability. They had at last attained equal political and legal status within their own hone. ${ }^{62}$

For Native Americans, however, the Umited States was not hone, and individual enfranchisement was not sufficient to ensure justice because the values of the tribes and the values of the dominant culture were so radically different. Liberal den1ocracy offers majoritarianisnı with the side constraints of individual rights. But m a nuajoritarian society, soine must win and some inust lose ${ }^{63}$ and if pervasively dissimilar cultures are yoked together within a single inajoritarian state, the mmority culture will lose systematically. For these mimority cultures, the promise of majoritarianism is not one of self-determination; it is rather one of subjection to an atien

60 See, e.g., Alvin M. Josephy, Jr., The Patriot Chiefs: A Chronicle of American Indian Leaderslip (1961); Richard White, The Middle Ground: Indians, Empires, and Republics in the Great Lakes Region, 1650-1815 (1991).

61 See generally Stephen Cornell, The Return of the Native: American Indian Political Resurgence 12-13 (1988); Joseplry, supra note 60.

62 Again, much recent commentary powerfully disputes this claim, arguing that individual enfranchisement and rights are not sufficient to secure justice for women and minorities. See, e.g., Robin L. West, The Difference in Women's Hedonic Lives: A Phenomenological Critique of Feminist Legal Theory, 3 Wis. Wonten's L.J. 81, 90-111 (1987). See generally Robin West, Jurisprndence and Gender, 55 U. Chi. L. Rev. 1, 4 (1988) (arguing that the abolition of patriarchy "is the political precondition of a truly ungendered jurisprudence"). The account, however, often surfaces in traditional legal analysis. See Regents of the Univ. of Cal. v. Bakke, 438 U.S. 265, 299 (1978) (opinion of Powell, J.) (explaining that majoritarian politics will adequately protect minority groups as long as individual minority members receive constitutional protection from discrimination against them as individual minority members); Williams, Borders, supra note 10, at 764-69 (exphicating Justice Powell's view of politics in Bakke).

63 See Sinopoli, supra note 41, at 91. 
power. ${ }^{64}$ While individual rights may shelter minority cultures to some degree, if a given community is not itself nidividuahstic, such protections may not be enough to preserve community selfdetermination. ${ }^{65}$

Liberal democracy, in other words, may offer the greatest possible opportunity for disparate groups to live together amicably within a single nation-state, but the very mechanisms that make cohabitation possible for some cultures-inajoritarianism, the franchise, and individual rights-also might serve to make cohabitation inipossible for others. Liberalisin niay seek to niake culture irrelevant to pohitical status, but ultimately hberahism is itself a culture, one that inposes its own orthodoxy. Although it may be appropriate to insist upon that orthodoxy within a given state avowedly and voluntarily committed to a hiberal creed, ${ }^{66}$ to seek to export that culture by arms-or by what is the same thing, forced ascribed consent-is simply imperiahsm.

The idea that liberal individuahisin may prove coercive to mmority cultures is not new to Annerican political thought. At the time of the Revolution, some of those who supported separating from Great Britam (rather than seeking actual representation in Parhiainent) did so because they believed that Americans had become a separate people with a culture significantly different from the Mother Country ${ }^{67}$ Later, the Constitution allocated structural representation in the Senate by state, not by population. As representatives of their respective states, the Founders beheved that the states had interests separate and distinct from one another, and the smaller states in particular feared that representation based on population would result in their perenmial defeat. ${ }^{68}$

Similarly, international groups have begun to propose safeguards for aboriginal peoples beyond those guaranteed by liberal individuahsm. Under these formulations, individual civil and political rights are deemed insufficient to protect aboriginal groups where

\footnotetext{
64 See Williams, Borders, supra note 10, at 824-30, 847-49.

65 See, e.g., Williams \& Williams, supra note 50, at 771-74.

66 See supra notes 50-51 and accompanying text.

67 See, e.g., Gordon S. Wood, The Creation of the American Republic, 1776-1787, at 2836 (1969).

68 See, e.g., Carl Van Doren, The Great Reliearsal: The Story of the Making and Ratifying of the Constitution of the United States 59, 122-28 (1948).
} 
the interests of the majority diverge from the interests of the minority. Instead, the new proposals recominend extensive structural protection for indigenous peoples, such as collective selfdetermination and group representation in the legislature. ${ }^{69}$ American scholars have argued powerfully that these innovative protections, designed for aborigmal peoples generally, should extend to Native Americans in particular. ${ }^{70}$ These scholars have the support of many tribal Indians themselves, who have long maintained that without tribal governments, tribal culture cannot long survive. ${ }^{71}$

Congressional, judicial, and presidential affirmations of the importance of tribal self-determination seem to be premised on exactly this view, that Indians are a separate people with a distinct culture requiring some measure of self-determination in order to avoid being swamped by the cultural norms of the inajority. ${ }^{72} \mathrm{Par}$ adoxically, by conceding that point Congress denies its own authority to enact legislation making that concession, for if Indians really are a separate people, then-in a hberal democratic universe purged of inperialism-Congress could never have acquired authority over then. But if Congress has no authority over the tribes, it can have no right to grant or withhold rights of tribal selfdetermination.

Indeed, if the Court looked only to the Indian law statutes under study (rather than to some pohtical theory) to supply a theory of interpretation/legitimation, it still could not employ its conventional interpretive method-rehance on legislative intent. The

69 See infra notes 343-52 and accompanying text.

70 See Russel L. Barsh, Indigenous North America and Contemporary International Law, 62 Or. L. Rev. 73 (1983); Robert N. Clinton, The Rights of Indigenous Peoples as Collective Group Rights, 32 Ariz. L. Rev. 739 (1990); Rachel San Kronowitz, Joanne Lichtman, Steven P. McSloy \& Matthew G. Olsen, Comment, Toward Consent and Cooperation: Reconsidering the Political Status of Indian Nations, 22 Harv. C.R.-C.L. L. Rev. 507, 586-622 (1987); Robert A. Williams, Jr., Encounters on the Frontiers of International Human Rights Law: Redefining the Terms of Indigenous Peoples' Survival in the World, 1990 Duke L.J. 660.

71 See Philip S. Deloria, The Era of Indian Self-Determination: An Overview, in Indian Self-Rule: First-Hand Accounts of Indian-White Relations from Roosevelt to Reagan 191 (Kenneth R. Philp ed., 1986); Frank Pommersheim, The Reservation as Place: A South Dakota Essay, 34 S.D. L. Rev. 246, 255-57, 260-61 (1989).

72 See Ex parte Crow Dog, 109 U.S. 556, 568-71 (1883); Oliphant v. Suquannish Indian Tribe, 435 U.S. 191, 208, 210-11 (1978); supra notes 62-66 and accompanying text. 
key substantive issue in inost recent Indian law cases is the extent to which the tribes exist as separate political communities under federal law. ${ }^{73}$ If tribes inay be deenied separate political communities by the very texts being interpreted, then courts inay not presuppose as part of their interpretive technique that tribes are not separate political communities. But at the heart of the conventional legislative intent inodel is the assumption that Congress holds authority over United States citizens as a single people yoked by consent into a inajoritarian deinocracy. If texts can teach interpreters how to interpret then in a dialogue between reader and text, then part of what these texts have to teach is that Indian tribes are different. ${ }^{74}$

In short, for at least three reasons it would be inappropriate to ascribe to the tribes consent to inclusion within the United States political order. First, they were here first and actively resisted inclusion. Second, inclusion into a inajoritarian order would involve cultural suicide for thein. Third, the United States governinent has itself legislated upon the premise that full assimilation would be illegitinate.

\section{Post-Hoc Consent}

Other theories based on social contract concepts-especially those associated with David Hunie and Thoinas Hobbes-describe consent not as the antecedent of good government, but as its product. According to Hunie, willing and habitual consent usually results froin years of living under a government that well serves its citizens' interests. In his language, the "opinion of interest" produces the "opinion of right."75 Hobbes, on the other hand, argued that just states often originate in the armed might of a powerful

73 See, e.g., County of Yakima v. Confederated Tribes \& Bands of the Yakima Indian Nation, 112 S. Ct. 683 (1992); Brendale v. Confederated Tribes \& Bands of the Yakima Indian Nation, 492 U.S. 408 (1989); Cotton Petroleum Corp. v. New Mexico, 490 U.S. 163 (1989).

74 For amplification of this point, see infra notes $336-59$ and accompanying text.

75 David Hume, Of the First Principles of Government, in 3 David Hume, The Philosophical Works 109, 110 (Thomas H. Green \& Thomas H. Grose eds., 1882 \& photo reprint 1964) (1777); see David Hume, Of the Original Contract, in 3 Hume, The Philosophical Works, supra, at 443, 443-60 (1777); David Hume, Of the Origin of Government, in 3 Hume, The Philosophical Works, supra, at 113, 115-16 (1777); see also Simopoli, supra note 41, at 78-79 (discussing Hume). 
sovereign. After that sovereign has provided orderly and effective government for many years, citizens come to consent to that sovereign's administration in gratitude and reliance. ${ }^{76}$

Despite their many differences, Hume and Hobbes thus share the view that consent is more often the result of good government than its necessary predicate. Congress miglit find such theories especially useful in defending its power over the tribes. While its jurisdiction over Indian affairs may not have originated in consent (indeed, it mostly originated in violence), given enough time, the argument goes, the tribes will come to consent to Congress' orderly and beneficent administration. The tribes may not now consent, but these theories are by their nature evolutionary: eventually, the tribes will come to feel affection for and allegiance to the Federal Government. Accordingly, in the short term we need merely ignore signs of tribal disaffection in the expectation that ultimately the United States will become a fully integrated, fraternal nation.77

Although niany citizens and pohticians may endorse this theory of evolutionary consent as a means of legitimating Congress' power over the tribes, that endorsenient suffers from several difficulties. First, the theory may be just plain wrong. It is unclear that consent ever does or can arise from violence; mdeed, far from creating commumity, violence may permanently poison the well. ${ }^{78}$ Second, those who do stand behind this theory as applied to the tribes may wish to avoid applying it generally. They may beheve that while the theory justifies Congress' power over the tribes, it in no way would justify, say, a French invasion of Denmark in the expectation

76 Thomas Hobbes, Leviathan 112-13, 129-33 (Michael Oakeshott ed., 1947) (1651).

77 In discussing a similar "origin story," Milner Ball points out that violence against the tribes "has never come to an end." Ball, supra note 9, at 10. But as argued in the text, Hobbesians may not find that arguinent persuasive: the violence has not yet come to an end, but that fact does not mean that it never will.

78 See Robert M. Cover, Violence and the Word, 95 Yale L.J. 1601, 1629 (1986). As Milner Ball asks rhetorically of the Roman conquests that supposedly led to consent:

Who besides Romans looked upon Rome as a liberating, resurgent Troy? Was the criine acknowledged to he at its core ever worked out of the Roman system? ... For that matter, when has revolution in the West ever escaped the vicious cycle by which it finally fails, consuming itself and eventually producing the need for another revolution? When has there not been in the end as in the beginning a crime in the pohtics of the world?

Ball, supra note 9, at 9 n.29. 
of future consent. ${ }^{79}$ Behind this view, in other words, may lie the old racist assumption that a "superior" culture has the right forcibly to subsume an inferior one, but that the saine right does not apply among civilized nations.

More significant from a judicial point of view, however, is the fact that legitimation based on post hoc consent (whatever its merits in the abstract) will not serve courts very well in the interpretation of statutes regulating Indian affairs. Again, the very statutes subject to judicial scrutiny currently assert that the best future for the tribes is not one of gradual (if forcible) assimilation but of separate self-determination. ${ }^{80}$ The statutes' substance thereby contradicts the Hobbesian/Humean theory of legitimation and interpretation proposed for them. In that sense, a judicial interpreter today stands in a very different position from that of a judge resolving such disputes in the nineteenth century, when the tribes' projected future entailed ultimate absorption. Under that premise, a Hobbesian interpretive norm would have fit the regnant Hobbesian statutes very well. Modern statutes, however, are overtly antiHobbesian, and a Hobbesian interpretive norm can serve only to obscure their meaning.

This, then, is the conqueror's anxiety: conquest will not justify Congress' power because conquest is illegitimate, and consent will not justify it because the tribes in no meaningful sense consented. Yet Congress continues to legislate, and the Court is unwilling or unable to deny its power to do so. As a result, the Court is without its standard devices for justifying Congress' authority, and thus it is also bereft of its standard devices for interpreting Congress' actions. Agam, I do not mean to say that courts consciously worry about the lack of a plausible interpretive paradigm, but like it or not, that problem resurfaces every time they purport to construe a federal statute regulating Indian affairs. I also do not mean to argue that Congress' authority over the tribes cannot be justified; rather, I contend that such a justification is not presently available in common currency. As Milner Ball has brilliantly argued, the

79 Similarly, many who are impatient with tribal demands for sovereignty may nonetheless be sympathetic to Scottish demands for home rule or Catalan demands for federation.

80 See infra notes $129-32$ and accompanying text; Williams, Borders, supra note 10 , at 852-58. 
modern Court asserts that the tribes have been mcorporated into the federal polity, but it has never explained how or when. ${ }^{81}$

In recent years, a new array of interpretive theories offering accompanying theories of legitimation has appeared on the academic horizon. Within the scope of their assumptions about the basis for Congress' general authority, each of these concepts may be intriguing, persuasive, and significant. As I will argue in the next Part, however, none of these theories persuasively describes the relationship of Congress to the Indian tribes.

\section{NEW THEORIES OF INTERPRETATION}

\section{A. Scalia and Textualism}

Since his elevation to the High Court, Justice Antonin Scaha's work in statutory interpretation has garnered widespread and intense attention. ${ }^{82}$ To sonie extent, this scrutiny may simply reflect the fact that Justice Scalia is in a position to put his theory into practice. In part, however, Scaha's work nuay attract notice because he possesses an uncommonly coherent and articulate theory of interpretation. According to Scalia, judges should look primarily to the "ordinary ineaning" of the statute's language, supplemented by compliance with certain canons of construction and by analogical reasoning based on the use of similar words in other legal contexts. ${ }^{83}$ Importantly, judges generally should not consider policy concerns, divine legislative intent, or consult legislative history. ${ }^{84}$ Scaha has given no indication that this theory's interpretive scope is less than universal, a method appropriate for all statutes at all times. Moreover, he has made it abundantly clear of late that he beheves his mode of statutory interpretation may be used to construe federal Indian statutes in particular.

81 See generally Ball, supra note 9, at 20-45.

82 See, e.g., Eskridge, supra note 1; Farber \& Frickey, supra note 11; George Kannar, The Constitutional Catechism of Antonin Scalia, 99 Yale L.J. 1297 (1990); Popkin, supra note 5 .

83 See Eskridge, supra note 1, at 652-55; Farber \& Frickey, supra note 11, at 454-55; Popkin, supra note 5, at 1140-52. According to Scalia, judges may ignore the "ordinary meaming" of the text only when it would produce results that are absurd. See Popkin, supra note 5 , at 1137,1163 .

84 See Eskridge, supra note 1, at 652-53; Farber \& Frickey, supra note 11, at 437-43; Popkin, supra note 5, at $1135-37$. 
1. County of Yakima v. Confederated Tribes \& Bands of the Yakima Indian Nation ${ }^{85}$

Last Term's Yakima Indian Nation required the Court to consider the states' power to tax Indian fee lands within a reservation. As in many Indian law cases, the statutory scheme concerned is quite comphicated, involving two statutes of very different vintages, the Indian Reorganization Act of $1934^{86}$ and the Indian General Allotment Act of $1887 .{ }^{87}$

Before 1887, most Indian land was held tribally, with beneficial title in the tribe and legal title in the United States. In an attempt to reduce the importance of the tribe to its members, ${ }^{88}$ Congress passed the General Allotment or Dawes Act. This Act instructed the executive to divide the great tribal holdings into smaller parcels, which would then be allotted to individual tribal members. These individuals would receive a beneficial interest for twentyfive years, with legal title remaining in the Umited States. At the end of that term, the property owners would receive fee simple patents on their allotments. ${ }^{89}$ In 1906, however, Congress passed the Burke Act, ${ }^{90}$ which allowed the Secretary of the Interior to short-circuit this process. If the Secretary found that an individual Indian was capable of managing his or her own affairs, the Secretary could issue a "forced-fee" patent before the twenty-five-year trust period had expired. ${ }^{91}$

The allotment process took time, and by 1934 the pattern of Indian landholding varied widely on different reservations. Some land had passed into the hands of individual Indians in fee, other portions remained in trust for individual Indians, while the balance had never been touched, remaming tribal trust land. In 1934, Congress enacted the Indian Reorganization Act ("IRA"), which halted the entire allotment process. Although the IRA did not specifically repeal any provision of the Dawes Act, it did order the

\footnotetext{
85112 S. Ct. 683 (1992).

86 Ch. 576,48 Stat. 984 (codified as amended at 25 U.S.C. $\$ \$ 461-479$ (1988)).

87 Ch. 119, 24 Stat. 388 (codified as amended in scattered sections of 25 U.S.C.).

88 Yakima Indian Nation, 112 S. Ct. at 686.

$89 \S 5,24$ Stat. 389 (codified as amended at 25 U.S.C. $\$ 348$ (1988)).

90 Ch. 2348, 34 Stat. 182 (1906) (codified at 25 U.S.C. $\$ 349$ (1988)).

9134 Stat. 183.
} 
Secretary to suspend the allotment procedure. ${ }^{92}$ Thus, to this day, Indians hold land in fee simple, individual trust, and tribal trust within reservation boundaries.

Yakima County collected two taxes on Indian fee land located within a reservation's boundaries: an ad valorem tax on the value of the fee property and an excise tax on its sale. In 1987, Yakima County began to foreclose on properties on which taxes were past due, and im response the Yakima Nation imitiated an action for declaratory and imjunctive rehef. ${ }^{93}$ Eventually, that action resulted in the inost important decision on Indian law handed down last Term.

In his opinion, Justice Scalia first outlined certain canons of construction. In 1832, Chief Justice Marshall began with the "premise that the 'several Indian nations [constitute] distinct political coinmunities, having territorial boundaries, within which their authority is exclusive," $"$ b4 but in more recent years, the Court has abandoned such absolute "'platomic notions of Indian sovereignty." 95 Instead, the Court has held that states may exercise jurisdiction over non-Indians on Indian Country absent evidence of congressional will to the contrary; and that states may exercise jurisdiction over Indians themselves to the extent that it does not interfere with their self-government. ${ }^{96}$ In the special area of state taxation of reservation Indians and Indian lands, however, the Court has adopted a categorical approach: states may not tax unless Congress has authorized thein to do so and has "'made its intention to do so unmistakably clear." "97

Using this rule of interpretation, Scalia consulted the statutes' language for evidence of such unmistakable intention, and, im a tour de force of strict textualism, found permission for the ad valorem but not the excise tax. Section 6 of the Dawes Act broadly provides that at the trust period's expiration "each and every allot-

92 Ch. 576, §§ 1-2, 48 Stat. 984 (codified at 25 U.S.C. $\$ \$ 461-462$ (1988)).

93 Yakima Indian Nation, 112 S. Ct. at 687.

94 Id. (quoting Worcester v. Georgia, 31 U.S. (6 Pet.) 515, 556 (1832)) (alteration in original).

95 Id. at 687 (quoting McClanahan v. Arizona State Tax Comm'n, 411 U.S. 164, 172 (1973)).

96 Id. at 688.

97 Id. (quoting Montana v. Blackfeet Tribe, 471 U.S. 759, 765 (1985)). 
tee shall have the benefit of and be subject to the laws, both civil and criminal, of the State or Territory in which they may reside."98 In 1906, the Supreme Court held that state tax laws were among the laws to which fee-patentees were subject. ${ }^{99}$ On the face of the Dawes Act, then, Yakima Indian Nation would seem to be an easy case: Indians holding fee patents are subject to all state laws, including tax laws.

Precedent, however, has intervened: Indian patentees are no longer subject to all state laws. Some years ago, Montana sought to impose various taxes on Indians living on trust and fee land alike. In Moe v. Confederated Salish \& Kootenai Tribes, ${ }^{100}$ the Court rejected the contention that section 6 gave the state the authority to impose these taxes. According to the Court, section 6 apphed only to fee lands, so that the tax on trust lands was invahid. ${ }^{101}$ New statutes, moreover, had altered the taxability even of the remaining fee lands:

The State has referred us to no decisional authority-and we know of none-giving the meaning for which it contends to $\S 6$ of the General Allotment Act in the face of the many and complex intervening jurisdictional statutes directed at the reach of state law within reservation lands .... Congress by its more inodern legislation has evinced a clear intent to eschew any such "checkerboard" approach within an existing Indian reservation [i.e., an approach in which jurisdiction turns on the form of land holding, trust, or fee]..$^{102}$

How the decision in Moe was was to be construed was therefore critical to Yakima Indian Nation's outcome, but the parties differed over its proper interpretation. The tribe offered the following rendition: the IRA and later statutes (the "intervening jurisdictional statutes") effectively repealed section 6 of the Dawes Act to avoid checkerboard jurisdiction. ${ }^{103}$ While the tribe admitted that no statute makes that repeal express, the pohicy worlds from which the pre- and post-1934 statutes originated are unmistakably different.

9825 U.S.C. $\S 349$ (1988).

99 Goudy v. Meath, 203 U.S. 146, 149 (1906).

100425 U.S. 463 (1976).

101 Id. at $477-78$.

102 Id. at 479.

103 Yakima Indian Nation, 112 S. Ct. at 691-92. 
Whereas the Dawes Act sought to extinguish the tribes and assimilate individual Indians rapidly into the inainstream, the IRA sought to restore tribal government, preserve reservation boundaries, and stop Indian land loss resulting from improvident sale or foreclosure. The Yakima County tax clearly undercut this latter pohicy: by foreclosing on the land, the state reduced the tribal land base and coinpromised the geographical integrity of tribal government. ${ }^{104}$

However, the policy conflict between the Dawes Act and the IRA is evident only upon examining tlie purposes reflected in the two statutes; it camiot be derived from their explicit language alone. Without uttering a word about the IRA's purpose or legislative history, Scalia casually dismisses the implicit repeal argument by mvoking a canon: "[The tribe's argument] is not supportable ... since it is a 'cardinal rule . . that repeals by implication are not favored." 105 Instead, Scalia offers a different interpretation of $M o e$, contending that the Court's decision was based on the literal language of section 6 , rather than the inplicit purpose of the IRA. Section 6 provides that upon the expiration of the twenty-five-year trust period, "every allottee sliall ... be subject to the laws" of his state. ${ }^{106}$ But according to Scaha, "allotee" refers only to the actual individual who received the allotinent, as opposed to any subsequent owner. Therefore, section 6 gave the states jurisdiction only over that initial generation of allottees-almost all of whoin are now dead. As a result, according to Scalia's interpretation of Moe, Montana could not impose im personam jurisdiction over the allotments' modern owners. ${ }^{107}$

104 Id. at 692 . Under recent precedent, the transfer of property to non-Indians constituted not only a property loss for individual Indians, but also a jurisdictional inpairment for the tribe. According to a plurality of the Court (perhaps now a majority with the addition of Justice Clarence Thomas), the tribe has jurisdiction over non-Indians only on tribal trust land within the reservation, but it has aboriginal jurisdiction over its own inembers everywhere on Indian Country. See, e.g., Brendale v. Confederated Tribes \& Bands of the Yakima Indian Nation, 492 U.S. 408, $422-32$ (1989) (plurality opinion).

105 Yakima Indian Nation, 112 S. Ct. at 690 (quoting Posadas v. National City Bank, 296 U.S. 497, 503 (1936)). Scaha also points out that the Moe Court never expressly referred to an implicit repeal. Id. at 690.

10625 U.S.C. $\$ 349$ (1988) (emphasis added).

107 Yakima Indian Nation, 112 S. Ct. at 690. 
Froin a perspective informed by legislative intent, that interpretation is decidedly peculiar. Under Scalia's rendering, the Dawes Act creates a window of jurisdiction: states may take jurisdiction over the initial allottees, but later lose their hold as the land gradually passes into new owners' hands. It is hard to imagine any rational legislature creating such a statute; it is harder still to iniagine the Dawes Act Congress doing so. By Scalia's adinission, that Congress wislied to pliase out tribal sovereignty, not reduce it and tlien phase it back im again. ${ }^{108}$ Not surprisingly, Scalia fails to offer one bit of legislative history to support his interpretation. But tlren, Scalia plainly does not feel the need to consult legislative intent or legislative history: the text says "allottee," not "allottee and subsequent owners," and that is the end of the matter.

Justice Scalia, of course, is not done; so far, he liad failed to find any express language permitting state taxation of Indian fee lands im section 6 , which deals witl jurisdiction. He finds such permission instead in section 5 of the Dawes Act, which governed the granting of fee patents. Under section 5, at the trust period's close the allottee was to receive a patent in fee which allowed him to alienate his land. ${ }^{109}$ According to Scalia, when lands become alienable, they generally become taxable as well:

[A]lthough it was certainly possible for Congress to "grant the power of voluntary sale, while withholding the land from taxation or forced ahenation," such an intent wonld not be presumed unless it was "clearly manifested ... . [because] it would seem strange to ... permit the Indian to dispose of his lands as he pleases, while at the same time releasing it [sic] from taxation."110

In short, then, section 6 gave in personam jurisdiction over the original allottee; section 5 implicitly gave in rem jurisdiction over the land. The former provision is now an effective nullity because of the passage of time, but the latter provision is alive and well and controlling in this case.

To bolster this connection between alienability and taxability, Scalia refers to another section-the Burke Act proviso. ${ }^{111}$ Upon

108 Id. at 686.

10924 Stat. 389 (1887) (codified as amended at 25 U.S.C. § 348 (1988)).

110112 S. Ct. at 691 (quoting Goudy v. Meath, 203 U.S. 146, 149 (1906)).

11125 U.S.C. $\$ 349$ (1988). 
the issuance of a forced-fee patent-a patent issued before the trust period's expiration-the Burke Act provided that "fee ownership would free the land of 'all restrictions as to sale, incumbrance or taxation." "112 Thus, this proviso allowed the state to tax the land as soon as it becaine taxable-but it did not allow the state to take general in personain state jurisdiction until the end of the normal twenty-five-year span. By its terms, the Burke Act proviso apphes only to forced-fee patents, but to Scalia it suggests a general connection between taxability and ahenability. As a result, the Dawes Act authorized Yakima County's ad valorem tax because it was a tax on alienable land. ${ }^{113}$

It is possible to criticize Scalia's reasoning at every stage of this argument. Because he ignores the statute's purpose, his interpretation of section 6's language is woefully implausible, revealing a wooden literalism. To supplement the text of the Dawes Act, he picks and cliooses his canons to reach an apparently preferred result. ${ }^{114}$ On the one hand, he gives the canon against implicit repeal treinendous force so as to keep the Dawes Act generally ahive. On the other hand, he gives Indian law canons scant if any weight. For example, the connection between taxability and atienability in section 5 is at best nnplicit, but the Indian law canon requires that Congress make its intent "unmistakably clear" before states inay tax. In addition, the canon requiring the Court to interpret ambiguous statutes in the Indians' favor ${ }^{115}$ fails to appear in Scalia's interpretation of section 5 as an implicit permission to tax land. Finally, Scalia argues that the Burke Act's connection between ahenability and taxability for forced-fee patents indicates a general connection between alienability and taxability, but it could have just the opposite meaning: when Congress wanted to grant permission to tax alienable land, it knew how to do so, and it so provided in the Burke Act but not in section 5. In any event,

112112 S. Ct. at 691 (quoting 25 U.S.C. § 349).

113 Id. at 692. By contrast, Scalia holds that the Dawes Act did not authorize Yakima County's excise tax because it was a tax not on land, but on the sale of land. Id. at 694. 114 Others have noted this selectivity about the use of canons in other fields. See Eskridge, supra note 1, at 663-66.

115 See, e.g., Bryan v. Itasca County, 426 U.S. 373, 392 (1976) (holding that ambiguous statutes enacted for the benefit of the Indians are to be liberally construed); Menominee Tribe of Indians v. United States, 391 U.S. 404, 406 n.2 (1968) (stating that treaties are to be construed as the Indians would have understood then). 
Congress' decision to make forced-fee patents taxable does not indicate an unmistakable intent to make regular patents taxable. ${ }^{116}$

My present point, however, is not that Scalia can be criticized for woodenness, imconsistency, and results-oriented reasoning. Rather, it is that Scalia purports to use the same methods to mterpret Indian statutes as those he purports to use in other fields of law. He begins with what he considers to be the text's "plain ineaning." "Allotee" ineans "allottee" and no one else; in ordmary legal usage, "ahenability" often includes the notion of taxability. If the meaning of the text is murky, he will use canons-but only certain canons - to render it more apparent. Significantly, he shows a marked dispreference for Indian law canons; the canons that dominate, like that agamst implicit repeal, are taken from other fields. $\mathrm{He}$ also refers to how terms are used im other statutes, or in other provisions of the same statute, to buttress his readimg of the plain meaning or to make meaming plam. For example, he supports his interpretation of section 5 by cross-referencing the Burke Act proviso. Finally, he declines to deduce legislative purpose, consider policy consequences, ${ }^{117}$ or consult legislative history.

Behind this very distinctive theory of interpretation lies a theory of legitimation. In applying his interpretive method to Indian law, Scalia is implicitly claiming that the legitimate basis of Congress' authority over the Indians is the same as that which justifies Congress' general authority over non-Indians. In the next Section I will consider Scalia's theory of legitimation and argue tliat, even when taken on its own terms, it cannot plausibly be applied to the special area of Indian law.

\section{Textualism and Indian Law}

Scalia's defense of textualism rests centrally on his belief that it promotes democracy rather than rule by judges or legislative

116 It is not inconceivable that Congress would have wanted to make forced-fee patents-but not regular patents-taxable since to issue a forced-fee patent the Secretary has to make an individualized finding that the patentee was "competent and capable of managing his or her affairs." 25 U.S.C. \$ 349 (1988).

117 States Scalia, "[i]n any case, [the tribes"] policy objections do not belong in this forum. If the Yakima Nation beheves that the objectives of the Indian Reorganization Act are too much obstructed by the clearly retained remnant of an earlier policy, it must make that argument to Congress." Yakima Indian Nation, 112 S. Ct. at 692. 
aides. ${ }^{118}$ Many have noted Scalia's concern with enunciating clear and categorical rules so as to restrain judicial will in individual cases. He eschews balancing tests and "totahity of the circumstances" analyses. ${ }^{119}$ Iinportantly, he clains that by focusing on the text judges will encourage legislators to draft clearer and inore exphicit statutes and thereby promote the better transmission of meaning. Writing against a background in which the ordinary usage of words is presumed, the canons of construction enforced, and the analogous use of words in other legal inaterials considered, the legislature will be able to make its will known by einploying clear language that will be interpreted predictably. ${ }^{120}$

Scaha's most notable claim is that to serve deinocracy, judges should ignore legislative history and claims about "legislative intent." Asserting that legislative purpose and history are inherently mamipulable, Justice Scalia inaintains that judges can find evidence supporting any result they wish to reach in the legislative record. ${ }^{121}$ In addition, he clains that all too often legislative history reflects primarily strategic behavior by committee members or even legislative aides, who seek to record their preferred reading of the statute. ${ }^{122}$ Moreover, in the process of making law, Scalia notes, inembers of Congress and the President explicitly agree only on the statute's language-not the thinking recorded in soine attached body of material developed by a small number of especially interested parties. ${ }^{123}$ Only by focusing on the text itself-as read against a background of rules designed to better understand

118 See Eskridge, supra note 1, at 652-54. Scalia believes that textualism provides other benefits as well. It will, for example, reduce arbitrary judicial decisionmaking and encourage the formulation of clear rules on which citizens may rely. See Popkin, supra note 5, at 1164-68; cf. Kannar, supra note 82, at 1303-08. Promoting democracy is, however, essential to Scalia's theory of legitimation. One can hardly imagine Scalia arguing that while textualism may frustrate democracy, judges should nonetheless be textualists in order to promote predictability. Without the prop of denocracy, the whole edifice falls, and I contend precisely that the prop has toppled in the case of Congress' autliority over the tribes.

119 See Antonin Scalia, The Rule of Law as a Law of Rules, 56 U. Chi. L. Rev. 1175, 1178-80 (1989).

120 See Eskridge, supra note 1, at 654-55; Popkin, supra note 5, at 1168 \& n.193.

121 See Eskridge, supra note 1, at 654; Popkin, supra note 5, at 1136.

122 See Eskridge, supra note 1, at 652; Farber \& Frickey, supra note 11, at 437-43.

123 See Eskridge, supra note 1, at 654; Popkin, supra note 5, at 1162-63. 
and consistently interpret such texts-can the messages from the political branches to the courts be transmitted effectively.

Scalia's theory of legitimation, then, is substantially similar to the legislative intent model. Indeed, Scaha has no quarrel with the ultimate goal of the legislative intent approach, only with its method of achieving that aim. He contends that his imterpretive strategy of adhering to the text and deriving clear rules will better preserve democratic order and restrain judicial willfulness than will attemptimg to glean legislative purposes. ${ }^{124}$ With Yakima Indian Nation, Justice Scalia has extended his theory of interpretationand with it his theory of legitination - to the field of Indian affairs. $\mathrm{He}$ is thereby miplicitly claiming that Congress' authority in the field of Indian affairs is legitimate because it is democratic.

But that claim fares no better when it issues from Scalia's textualism than when it follows from the legislative intent model. ${ }^{125}$ Both fail to explain the origin of Congress' legitimate democratic authority over the tribes. The tribes never consented to being subsumed into the Nation; they cannot be presumed to have consented; and the protections afforded by enfranchisement and guaranteed constitutional rights are insufficient to protect a minority culture from majoritarian depredations. Liberal mdividualist democracy smiply does not work very well in this corner of the woods.

Again, I do not mean to contend that no argument for Congress' authority could be mustered-only that Scaha has offered none and that the conventional arguments will not serve. He begins with a method developed in other areas of the law and then blithely transfers it to the field of Indian affairs. In that transimssion, he never stops to consider whether the shift in field might also involve a shift im the nature of Congress' authority, and so a shift in the proper interpretive strategy. Yakima Indian Nation thus skids

$124 \mathrm{He}$ might be wrong in that contention. As one commentator has argued, Scalia's method pays hittle attention to the real democratic will of a "flesh and blood" legislature; instead, it hypothesizes a legislature that always uses terms consistently, says exactly what it means in the text of statutes, and employs impeccable grammar. Popkin, supra note 5, at 1160.

${ }_{125} \mathrm{My}$ argument is simply that Scalia's technique is inappropriate on its own terms to the particular fleld of Indian law. Many have argued, however, that Scalia's method may be inappropriate to any field of legislation. See Eskridge, supra note 1; Farber \& Frickey, supra note 11, at 448-52; Popkin, supra note 5, at 1161-86. 
along on an unarticulated but indispensable assumption that Congress' authority is fundannentally unitary.

Scaha might well respond to this critique by asserting that courts have no business inquiring into the basis of Congress' authority. But he has nrade that response unavailable to himself, for in developing his own theory of interpretation Scalia quite self-consciously inquired into the basis of Congress' authority (den1ocracy) and pondered what interpretive strategy would best serve that theory of legitimation (text and rule). Alternatively, he might argue that the courts nray not deny Congress' authority over any area-like Indian affairs-given to it by the Constitution. ${ }^{126}$ But again, that argunient (even if correct) reaches only the siniple conclusion that the courts cannot deny Congress' authority. It does not explain the nature of that authority and hence provides the courts with no guidance for interpreting Indian statutes. Indeed, Justice Scalia himself does not purport to derive his interpretive strategy froin the Constitution itself, but rather froin the importance of "judicial restranit" in light of the legislature's superior conpetence as a denuocratically elected lawmaking body. ${ }^{127}$

Finally, Scahia nnight argue that the attributes of liberal deniocracy-the right to vote and other protected constitutional rightsjustify Congress' authority over tribal Indians just as they vahidate congressional authority over everyone else. Although it is only speculation, I suspect that Scalia niay credit this claim, as he has shown little sympathy for efforts to preserve tribal self-governnient. But he has yet to construct this argument, and its exegesis would face substantial obstacles, mcluding growing international conviction that liberal democracy does not adequately protect aboriginal peoples.

Indeed, hberal denocracy's inability to protect the tribes is demonstrated not only by history and pohtical theory, but by the aims imderlying the statutes considered in Yakima Indian Nation itself. In the past, sonve have argued that a reader inust bring an interpretive technique to a text, rather than derive it from the text, because one could read a text so as to derive an interpretive tech-

126 U.S. Const. art. I, $\S 8, \mathrm{cl} .3$ ("The Congress shall have Power . . To regulate Commerce with foreign Nations, and among the several States, and with the Indian Tribes ....").

127 See Popkin, supra note 5, at 1161-64. 
nique from it only if one enuploys some preexisting interpretive technique in the reading-but then one can read only what that preexisting technique reveals. More recently, some have asserted that the process is more complex, that one must begin with sonie tentative technique, but that the text can cause one to revise it. The text can, in effect, teach the reader how to read it. ${ }^{128}$

If that view is correct, the inanner of interpreting Indian statutes suggested by the statutes themselves is complex, not to say contradictory. On the one hand, procedurally, Congress adopts Indian statutes in the sane way that it adopts all others-implying, perhaps, that they should be interpreted in the same way and that the nature of Congress' authority is the same. On the other hand, substantively, some of the statutes provide tribal Indians with special rights including limited sovereignty and self-government-treatment that undercuts the assumption that the basis of Congress' authority is unitary.

Yakima Indian Nation illustrates this tension. Although Justice Scahia devoted virtually his entire opinion to the Dawes Act, other statutes were at issue. For example, the Indian Reorganization Act provided a mechanism allowing the tribes to create constitutional governments that are permitted to engage in substantial amounts of on-reservation regulation. ${ }^{129}$ Moreover, Indian criminal statutes preempt state jurisdiction over crimes involving Indian defendants or victim $1 \mathrm{~s}^{130}$ within Indian Country-a term that imcludes all land within reservation boundaries, including fee land. ${ }^{131}$ Furtherinore, mdividual Indians are immune from some state regulation, a significant fact given that the states are often the nearest majoritarian institution of the dominant culture. Finally, an Indian's behavior nuay be regulated by his or her tribe-a government in which only Indians may participate. ${ }^{132}$ By providing individual Indians and tribal governments with such extraordmary protection aganist the states, these acts suggest that Congress believes that Indian tribal culture camot well survive in a large liberal deinocracy without

128 See William N. Eskridge, Jr., Gadamer/Statutory Interpretation, 90 Colum. L. Rev. 609,623 (1990).

12925 U.S.C. $\S 476$ (1988).

13018 U.S.C. $\$ \$ 1152-1153$ (1988).

13118 U.S.C. $\$ 1151$ (1988).

132 See Williams, Borders, supra note 10 , at 803 . 
some buffer from the winds of majoritarianism. But if that concern is real, Congress' authority over the Indians cannot rest on majoritariamsm alone, and if Congress' authority is therefore not unitary, then the bases guiding the mterpretation of Indian statutes cannot be umitary either. The assertion of power innphicit in the enactnient of statutes protective of tribal governments is thus contradicted by the content of those very statutes.

\section{B. The Market for Legislation}

\section{Theories of Interpretation and Legitimation}

Drawing on public choice tlieory and the law and econonics movement, certam scholars and judges have begun to examine how viewing the legislature as a forum for self-imterested pressure groups may influence statutory interpretation. While these commentators disagree over the implications to be derived from this model of the legislature, they agree in substance on the fundamental features of the model itself.

In the pohitical sphere no less than in the economic, human beings are assunied to be rational, self-interested welfare maximizers. The legislature is, in effect, a market for statutes: legislators want to be reelected, and interested parties want statutes, so legislators trade statutes for the political support necessary to win reelection. ${ }^{133}$ In this view, the mix of statutes enacted represents numerous compronises between competing private imterest groups, the equilibrium point of the market. ${ }^{134}$

That market, unfortunately, suffers fronı some severe dysfunctions. For example, proposals that entail widely distributed costs and/or benefits-such as imcreasing police or fire protection-will not stimulate the formation of interest groups intent on pressing for such legislation, for two reasons. First, each imdividual has only a sniall stake in acquiring or rejecting such "public goods"; althougl one may not wish to fund a new mass transit system, for instance, few would be willing to enter the public debate to oppose

133 Jonathan R. Macey, Promoting Public-Regarding Legislation Through Statutory Interpretation: An Interest Group Model, 86 Colum. L. Rev. 223, 227-33 (1986).

134 See William N. Eskridge, Jr. \& Philip P. Frickey, Legislation Scholarship and Pedagogy in the Post-Legal Process Era, 48 U. Pitt. L. Rev. 691, 703-05 (1987); Popkin, supra note 1 , at 564 . 
it, because the lobbying costs in time and money would be significant, whereas the mdividual tax burden for the transit system would be minimal. ${ }^{135}$ Second, individuals who do pursue public goods will experience free rider problems; citizens unwilling to act will have an incentive to rely on the efforts of those who are politically motivated without imvesting any effort or inoney theinselves. ${ }^{136}$ Consequently, few will be mclined to act when they must shoulder the entire burden of lobbying themselves. If this model is accurate, the legislature should produce relatively few pubhic interest statutes and should fail to update tlose tliat it does enact. By contrast, the legislature has every incentive to produce rent-seeking statutes-those that serve the mterests of sinall but organized and intensely concerned parties.

The vision of legislative activity depicted by the public clioice model is only descriptive, ${ }^{137}$ the connection between it and a prescription for interpretive technique is not self-evident. Indeed, some public choice tlieorists do not seek such prescriptions for judicial behavior at all; they aspire only to understand the working of the legislature. ${ }^{138}$ Otliers, however, do seek such guidance, led by two judges on the Seventl Circuit with roots in the University of Chicago Law School.

Richard A. Posner has recommended that when faced witl a problem of interpretation, judges should "innaginatively reconstruct" the intent of the legislature. ${ }^{139}$ In so domg, they should consider what the legislators-taking into account their values, concerns, and interests-would liave done if faced with the problem at bar. Public choice theory is thus relevant to ascertaining legislative intent because it provides judges with a more sophisticated understanding of the legislative process; ratlier than assume

135 See Frank H. Easterbrook, The Supreme Court 1983 Term-Foreword: The Court and the Economic System, 98 Harv. L. Rev. 4, 15-16 (1984).

136 See Eskridge \& Frickey, supra note 134, at 705-06; Macey, supra note 133, at 231-32.

137 And it may not be an accurate description. See Daniel A. Farber \& Philip P. Frickey, The Jurisprudence of Public Choice, 65 Tex. L. Rev. 873 (1987) (analyzing the usefulness of public choice models).

138 See James M. Buchanan \& Gordon Tullock, The Calculus of Consent: Logical Foundations of Constitutional Democracy (1962); George J. Stigler, The Theory of Economic Regulation, 2 Bell J. Econ. \& Mgmt. Sci. 3 (1971).

139 See Richard A. Posner, Statutory Interpretation-in the Classroom and in the Courtroom, 50 U. Chi. L. Rev. 800, 817-19 (1983). 
that the legislature acts benignly, judges should recognize that the legislature nray be engaged in the most self-interested of dealmaking. ${ }^{140}$ By the same token, however, Posner rejects a textualist canon-like that advocated by Justice Scalia or Judge Frank $H$. Easterbrook, as elaborated below-because it screens out relevant evidence of legislative intent. Instead, judges should consult not only the statute's language, but also every other scrap of legislative history on which they can lay their hands, seeking to grasp not only the letter of the law but also its "spirit."141 Occasionally judges may choose not to consult the specific intent of the legislature on a particular point, but only because the legislature intended that there be no specific intent. For instance, in drafting "common law statutes" like the Sherman Act, the legislature has essentially ceded to the judiciary the power to develop the statute's meaning on a case-by-case basis. ${ }^{142}$

Judge Posner, in short, advocates the traditional judges-as-passive-agents inodel, but with a specific understanding of the nature of legislative intent. Again, however, devotion to legislative intent as an interpretive technique cannot simply be assumed but must be defended. Interest group politics has a familiar defense: it best assures the widespread satisfaction of social wants, in much the same way as the nuarket does, because it reflects the intensity and distribution of societal preferences. ${ }^{143}$ Much of the point in recent public choice hiterature, however, is precisely that the legislature is a flawed market, failing adequately to reflect societal preferences. Thus it seems somewhat odd for Judge Posner to pledge unquestioning fealty to an institution that is of dubious legitimacy. For that reason, other public choice theorists have recommended interpretive strategies that depart fron a model of strict fidelity to legislative purpose.

For example, Judge Easterbrook divides legislation mto two categories-pubhic interest statutes and private interest deals. Easterbrook views the former in much the way that Posner views

140 Id. at 819.

141 Id. at 821.

142 Id. at $818-20$.

143 See Eskridge \& Frickey, supra note 134, at 706-08; Nicholas R. Miller, Pluralism and Social Choice, 77 Am. Pol. Sci. Rev. 734, 734-37 (1983); Popkin, supra note 1, at 565; Cass R. Sunstein, Interest Groups im American Public Law, 38 Stan. L. Rev. 29, $32-34$ (1985). 
"common law" statutes: the legislature has identified a problem and chosen to enlist the court to develop specific rules to be employed in dealing with that problem. Accordingly, courts may interpret such statutes loosely and with an eye toward their purpose. By contrast, private interest deals are merely compromises between two or more contending interests that precisely allocate the benefits that each party has managed to wrest from the legislative struggle. A division of spoils, they have no "purpose" beyond that division. Accordingly, judges should construe such statutes very narrowly, enforcing only the deal's literal terms. Courts thus have no power to fill in statutory gaps, amplify the statute, or adjust it to fit new circumstances by adducing "more of the same" spirit, precisely because the statute possesses no spirit. If the statute does not specifically address the problem at hand, the judge should deem it irrelevant; the problem is simply outside the statute's domain. ${ }^{144}$

At some points, Easterbrook defends this two-track interpretive scheme as a matter of simple fidelity to congressional will, suggesting that the legislature itself regards private interest deals and public interest regulation as different animals. As smart and honest agents, judges should therefore reflect that different understanding in their interpretation. ${ }^{145}$ At other points in his analysis, however, Easterbrook alludes to substantive concerns supporting a strict interpretation of private interest deals: he recommends this rule because it will limit rent-seeking legislative intervention imto the private sphere. By so defending his proposal, Judge Easterbrook indicates that his concern is not so much with following legislative intent as it is with limiting the scope of rent-seeking

144 See Easterbrook, supra note 135, at 14-16; Frank H. Easterbrook, Statutes' Domains, 50 U. Chi. L. Rev. 533, 540-46 (1983). At some points, Easterbrook asserts that even public interest statutes should be narrowly construed if the legislature has chosen to draw a precise line. States Easterbrook:

In the case of public interest legislation it is more likely that the legislature would authorize blank filling, but the extent of this preference is far from certain. If the purpose of the public interest statute is to come as close to the line of overregulation as possible-that is, to achieve the benefits of regulation right up to the point where the costs of further benefits exceed the value of those benefits-then to authorize blank filling defeats the purpose of the statute.

Id. at 541.

145 See Easterbrook, supra note 135, at 60. 
legislation and leaving the market free to flourish in its magnificent efficiency. ${ }^{146}$

Easterbrook would thus interpret rent-seeking legislation narrowly, but he would nonetheless recognize and accept it as rentseeking. Others would go even further to contain private interest legislation. Jonathan Macey discusses what he calls "hiddenimphicit" statutes, legislation that is in fact a deal between interest groups but wears the facade of public interest legislation. Interest groups find such statutes very attractive because they can secure rents froin the legislature while hiding the legislation's rent-seeking nature froin the general public. According to Macey's reading, Easterbrook would have judges seek out and enforce the "hidden" deal, thus allowing interest groups to benefit from their bargain while sheltering them from the fallout that they would receive if the deal were overt. ${ }^{147}$ But, argues Macey, such an approach only encourages rent-seeking, a practice that the courts need not further since judges are not obligated to promote legislative pathologies. Instead, Macey recominends an approach very much like the Hart and Sacks legal process method: judges should base their decisions on the statute's "plain ineaning," its publicly articulated purpose, and its legislative history, all the while assuming that the legislators were all reasonable persons acting reasonably. Judges will thus read "hidden-imphicit" deals as if they were pubhic interest statutes, and "by giving a statute its public rather than private meaning, [they] may reach a result that serves the pubhic interest, but fails to honor the terms of the original deal between the legislature and the interest group."148 If the legislature wants to enact a private deal, it may do so-but it must do so overtly and take the electoral fallout, for "the cost to special interest groups of legislative subterfuge is the probability that a court will be unable to discern, or will refuse

146 See William N. Eskridge, Jr., Politics Without Romance: Implications of Public Choice Theory for Statutory Interpretation, 74 Va. L. Rev. 275, 296-97 (1988) (discussing the implications of Easterbrook's approach). Posner denounces Easterbrook's theory on just these grounds, arguing that " $[t]$ o construe a statute strictly is to limit its scope and its hife span-to make Congress work twice as hard to produce the same effect." See Posner, supra note 139 , at 821 .

147 See Macey, supra note 133, at 238-39.

148 Id. at $250-52$. 
to recognize, the underlying bargain and will therefore fail to enforce the legislative compromise." 149

Macey, Easterbrook, and Posner thus all agree that judges may not deny Congress' constitutionally given power to enact a given statute. Nor may judges-in soine simple sense-substitute their own decisions for those made by the legislature. But neither of those convictions explains in a precise way how judges should interpret expressions of Congress' undoubted power. To develop a theory of interpretation, judges must consult the legitimate basis of Congress' power. If Congress is legitinate because it acts as an efficient market for statutes, then the interpretive task for courts is easiest when that market is acting efficiently. When it is not-as in the case of rent-seeking legislation-the basis for Congress' legitiinate power is less clear, and so is the interpretive technique that courts should use. Easterbrook recommends that courts should confine the scope of rent-seeking statutes. Macey suggests that courts should refuse to enforce deals unless they are overt, so as to make the inarket inore efficient by exposing rent-seeking legislation to public inspection. Ultimately, then, both commentators regard rent-seeking legislation as of suspect legitimacy, though each inaintains that Article III judges inust nonetheless enforce such statutes because of the brute fact of Congress' constitutional power. But both also insist that judges should interpret the legislation in such a way as to limit its damage-to make Congress' authority as legitimate as possible under the circumstances.

\section{Indians in the Market for Legislation}

Like the paradigms espousing adherence to legislative intent or textuahism, the market-for-legislation model does not adequately defend Congress' power over the Indians, and so it does not recommend itself as a basis for interpretation. The problem experienced in interpreting rent-seeking legislation is that because of particnlar market dysfunctions, the legislature fails to maximize preferences. The problem in construing legislation addressing tribal affairs is different; Indian preferences calmot adequately be expressed even in a perfectly functioning market inechanism, for two reasons. First, like many other minority groups, the tribes lack

149 Id. at 253. 
the resources to compete successfully in a market for legislation. Second, the tribes' fundamental desire is not to compete in the market at all. As a result, the legislative inarket does not operate as intended in this area, failing to provide Native Americans with a mechamism for the stable satisfaction of wants.

\section{a. The Distribution of Resources}

Public choice theory would presumably regard most federal Indian statutes as classic interest group legislation. Both the benefits and costs are concentrated on a small portion of the population: tribal Indians and those who have special dealings with them, like the extractive industries, non-Indian residents of reservations, and commercial fishing organizations. Many of these groupsmcluding many Indian tribes-maintam full-time Washington lobbyists. Indian tribes are formally organized interest groups, and Indian legislation reveals many of the features that Easterbrook regards as typical of interest group legislation: ${ }^{150}$ there are restrictions on entry into markets (sucli as tribal membership restrictions), ${ }^{151}$ monopohistic or ohgopolistic elements (such as rights to a portion of the fish harvest in various states), ${ }^{152}$ and restraints on alienation (especially of Indian land). ${ }^{153}$ Indeed, from this perspective, one striking feature of Indian law is the range, extent, and variety of statutes providing that the tribes shall be specially treated. If one looked only at Title 25 , one miglit conclude tliat the Indians are an uncommonly successful interest group and that the legislative market lias worked well for tliem. ${ }^{154}$

Yet this imitial impression is unwarranted; Indians are by any standard the most materially disadvantaged mmority group im the Umited States. ${ }^{155}$ Few Indians believe that the federal government

150 See Easterbrook, supra note 135, at 16-17.

151 See Williams, Borders, supra note 10, at 794-95 \& n.132, 803-04.

152 See Washington v. Washington State Commercial Passenger Fishing Vessel Ass'n, 443 U.S. 658 (1979); Department of Game v. Puyallup Tribe, 414 U.S. 44 (1973).

153 See 25 U.S.C. $\$ 177$ (1988).

154 Many non-Indians believe that Indians receive wildly disproportionate benefits and occupy a very cushy berth under the federal government's protective gaze. See Clinton, supra note 10 , at $980-81$.

155 See, e.g., David H. Getches \& Charles F. Wilkinson, Cases and Materials on Federal Indian Law 8-12 (2d ed. 1986) (noting that Indians' economic, health, and educational 
has the tribes' interests primarily at heart. ${ }^{156}$ Indeed, a casual visit to almost any Indian reservation should disabuse the most devoted public choice theorist of the notion that Indians are masters of the interest group game.

In part, the tribes' needs are neglected for all the same reasons that other discrete and imsular minorities' needs are neglected: the market tends to disadvantage those who are significantly different. ${ }^{157}$ A certain similarity of outlook or interest is essential to forming effective legislative coalitions. ${ }^{158}$ In addition, tribal Indians fail to prosper in the legislative market because they have hmited resources with which to "buy" statutes from legislators. In few if any districts do tribal Indians constitute a voting bloc of sufficient strength to determine electoral outcomes. ${ }^{159}$ Moreover, although some tribes do maintain Washington lobbyists, many are unable to do so because of the expense. Poverty also makes contributing to campaign coffers a tremendous hardship for most tribes. ${ }^{160}$ Although some of the interest groups that typically oppose Indian interests-such as small on-reservation non-Indian farmers--also suffer from such want of resources, many others-such as the extractive industries-are enormously well-funded and pohtically powerful.

Public clioice theorists typically defend markets as optimizing the satisfaction of preferences for a given distribution of political resources; they do not attempt to address whetlier the distribution of resources available to the players is fair. The poverty and isolation that tribal Indians experience are therefore simply not part of the range of concerns that public choice theory addresses. While a given market may produce unjust consequences because the initial distribution of funds and political clout was mequitable, public

conditions are poor and remarking that the only notable exception to their "have-not" existence is their ownership of land and natural resources).

156 See, e.g., Robert A. Williams, Jr., Gendered Checks and Balances: Understanding the Legacy of White Patriarchy in an American Indian Cultural Context, $24 \mathrm{Ga}$. L. Rev. $1019,1024-25$ (1990) (noting that Indian humor "direct[s] ridicule at the cultural icons and colomial bureaucracy of the domimant culture").

157 See United States v. Carolene Products Co., 304 U.S. 144, 152 n.4 (1938).

158 See Ely, supra note 41, at 105-79.

159 At present, Congress boasts one Indian representative. See Kevin Merida, For Campbell, Heritage Conies Before Tradition, Wash. Post, Sept. 20, 1993, at A17.

160 See Cornell, supra note 61 , at $180-81$. 
choice theory would maintam that a market is nonetheless the best mechanism for maximizing preferences within that distribution. ${ }^{161}$ A complete defense of any particular legislative inarket, then, would have to go beyond this poimt and defend the initial distribution of political resources as well.

No such defense can justify the current paucity of political resources available to tribal Indians. Indians today cannot "buy" legislation because they are poor and few, and both conditions are the product of violence. As Joseph Singer has powerfully argued, Indians are poor as a result of a sustained, racially based theft sanctioned by law. The conquest that Marshall felt himself compelled to accept forcibly transferred title to this country froin the aboriginal owners to foreign imterlopers. The present distribution of property im this country, in otlier words, rests not on some neutral market mechanisin but on racial bias and violence. ${ }^{162}$ Similarly, Indians are few today-and hence can muster few votes-because of the ravages of disease brought over from Europe, war with nonIndians, and starvation triggered by conquest and confinement to the continent's less productive portions. ${ }^{163}$

\section{b. Tribes and Markets}

In short, the legislative inarket does not adequately satisfy Indian preferences because Indians lack political resources. Tribal Indians share that problem with many other minority groups, and some might suggest that the reinedy may be found by tinkering with the market itself, redistributimg political resources and seeking to inake the market more responsive to minority concerns generally. Yet such an approach would be unavailing to the tribes because a deeper reason hes behind the market's failure to address their needs. Specifically, although the tribes have some preferences of the sort that the legislative market normally distributes (land, water, fish, health care, education, funding), many seek to

161 Cf. Guido Calabresi \& A. Douglas Melamed, Property Rules, Liability Rules, and Inalienability: One View of the Cathedral, 85 Harv. L. Rev. 1089, 1094 (1972) (discussing market forces leading to Pareto optimality).

162 See Joseph W. Singer, Sovereignty and Property, 86 Nw. U. L. Rev. 1, $41-45$ (1991).

163 See, e.g., Lenore A. Stiffarm \& Phil Lane, Jr., The Demography of Native North America: A Question of American Indian Survival, in The State of Native America: Genocide, Colonization, and Resistance 23 (M. Annette Jaimes ed., 1992). 
satisfy a unique preference-the right to govern themselves and rid the tribes of congressional oversight. They want, in other words, not to have to enter the legislative market at all. ${ }^{164}$ To some extent they wish to maintam their own "legislative market," one populated by Indian interest groups only. But the impulse to secede goes further; to some degree they wish to be governed by a nonmarket body. Although it is dangerous to overgeneralize, at least some Native Americans continue to believe that a government should serve the good of the whole people-conceived as intercoimected-rather than the preferences of each individual separately considered. ${ }^{165}$

The legislative market cannot accomodate this preference because the preference is precisely not to have preferences reflected in the legislative market. Under the legislative market model, the only way to advance that preference (i.e., to secure a self-determination statute) is to enter the market-and the preference is not to enter the market at all. The frustration of this preference, unoreover, is not himited to a simgle occasion; even if the tribes could secure a self-determination statute so as to retire from the market, they must still keep a hand in the market to prevent the legislature from modifying the statute. Ultimately, the tribes might be able to secure a constitutional amendment to protect their own governments, but under pubhic choice theory even the constitutional amendment process (and the possibility of repeal of amendments) are market-oriented. ${ }^{166}$ In any event, if a constitutional amendment were to grant tribes self-determination, it would no longer be appropriate to view Congress as a market in which the tribes must participate. Essentially, such an amendment would abohish the market for sovereignty-limiting Indian statutes.

Public choice theorists might reject this preference not to have a market on the grounds that it is really just a preference to have one's preferences counted more than anyone else's. After all, the defense of the legislative market is that it is the best mechamism available to maximize the preferences of all citizens, not just the

164 See Cornell, supra note 61, at 216.

165 See Russel L. Barsh, The Nature and Spirit of North American Political Systems, 1986 Am. Indian Q. 181, 187-89 (1986).

166 See, e.g., William M. Landes \& Richard A. Posner, The Independent Judiciary in an Interest-Group Perspective, 18 J.L. \& Econ. 875, 892-94 (1975). 
preferences of a few. ${ }^{167}$ If the legislative market will allow the tribes to secede from the market, then they may do so; however, that is a decision for the market, not the tribes, to make, because only the market can maximize preferences. At this poimt, however, pubhic choice theory runs aground on the tribes' special status. Legislative markets have boundaries. While im an ideal world we might have a global legislative market-like the budding commercial market-that would broker the preferences of the world's populations, today the people of the Earth are subdivided into sovereign states. Within each state, mdividual legislative markets may operate, but they normally do not have extraterritorial jurisdiction. Hence, the Umited States cannot legislate for the people of Sweden because it has never acquired sovereignty over them. Before we can imterpret Indian statutes as the creations of a legislative market, then, we must estabhish that the Umited States market has come to embrace the Indian tribes.

For the most part, public choice theory does not directly address the origin of sovereignty; rather, it assumes a stable state and then analyzes how pohicy is made within that state. It presupposes, im other words, that the market's present boundaries are legitimate, however they were acquired. But the most nagging questions plaguing Indian law are precisely questions of origin, boundary, and sovereignty: Can conventional American pohitical thought offer a satisfying description of the etiology of congressional power over the tribes? Like textualism, then, pubhc choice might be right within its domain, but that domain does not extend to the Indians.

Public choice discourse does, however, offer the seeds of a theory about the origin of sovereignty. As the legislative market's role is to maximize preferences, the origin of government must therefore he in the satisfaction of individual preferences as well. In this hight, it is not hard to give the Lockean social contract a public choice accent: in the mythical premarket world of atonnstic mdividuals, humans found it difficult to realize their preferences individually, so they created governmental markets, ceding to them the power to promote the general good (i.e., Pareto optinahity). ${ }^{168}$

167 See supra text accompanymg notes $143,161$.

168 See Richard A. Epstein, Takings: Private Property and the Power of Eminent Domain (1985). Others describe the Constitution as a product of interest groups' preferences, rather than individual ones. See Landes \& Posner, supra note 166, at 892-94. 
If tribal Indians ever went through such a process, however, it was to their tribal government that they ceded power, not to the United States government. As detailed above, nıost Indians becanie United States citizens by statute, not by individual choice. ${ }^{169}$ Although individual tribes did consent to soine measure of federal jurisdiction over them in peace treaties, agam, such treaties do not constitute a general grant of authority to Congress to legislate for the tribes; they are limited to their particular terms. ${ }^{170}$ Moreover, inuch-if not the overwhelming portion-of Congress' power over the tribes was acquired through force or the threat of force. As noted, John Marshall acknowledged that the existence of the United States depended on conquest. ${ }^{171}$ Over a century later, Justice Stanley Reed insisted that Congress could take aboriginal title (and presumably sovereignty over that land) through purchase or conquest. Indeed, if it so chose, Congress could dispense with the formality of conquest and enact legislation providing for expropriation instead. Reed declaimed:

Every American schoolboy knows that the savage tribes of this continent were deprived of their ancestral ranges by force and that, even when the Indians ceded millions of acres by treaty in return for blankets, food and trinkets, it was not a sale but the conquerors' will that deprived them of their land. ${ }^{172}$

The history of United States-Indian relations thus reveals very few occasions in which treaties were negotiated under market-like conditions. ${ }^{173}$ As soon as the Bluecoats' propensity for violence became known, it served as the background to every treaty. Every tribal leader knew that if negotiations fell through, the most likely alternative was war. Obviously, war is not a preference-maximizing device for all parties concerned; it maximizes the preferences only of the conqueror.

169 See supra text accompanying notes 47-49, 56-61.

170 See supra text accompanying notes 44-46.

171 See supra text accompanying notes 17-20.

172 Tee-Hit-Ton Indians v. United States, 348 U.S. 272, $289-90$ (1955).

173 See, e.g., Cornell, supra note 61; Patricia N. Limerick, The Legacy of Conquest: The Unbroken Past of the American West (1987); Robert M. Utley, The Indian Frontier of the American West, 1846-1890 (1984). 
In defending conquest as the origin of Congress' authority, Justice Reed explained that the Takings Clause does not protect aboriginal title:

In the hight of the history of Indian relations in this Nation, no other course would meet the problem of the growth of the United States except to make [discretionary] congressional contributions for Indian lands rather than to subject the Government to an obhgation to pay the value when taken with interest to the date of payment. ${ }^{174}$

In other words, if Congress had to pay for the territory it wished to acquire, the country's growth would be checked because Congress could not afford to pay the tribes' asking prices. Yet according to conventional economic analysis, if Congress could not meet the tribes' deinands, then title should not have changed hands; within that distribution of resources, the tribes wanted to keep the land more than Congress wanted to acquire it.

Public choice theory, then, can recognize the legitimacy of Congress' power over the Indians only by accepting the vahidity of conqest or by distorting history-by pretending that the continent's acquisition was more consensual than in fact it was. And even that distortion does not remove all obstacles to a public choice analysis, for the statutes and treaties themselves contradict the idea that Congress' power over the tribes rests on a model of the legislatureas-marketplace. One of the central legal concepts aminating Title 25 is Congress' fiduciary obhigation to the Indians, and nuinerous treaties contain congressional declarations pledging to care for the tribes. ${ }^{175}$ For example, many Indian-specific statutes begin by stating that Congress passed the particular statute in recognition and execution of its fiduciary duty. ${ }^{176}$ The theory of legitimation/interpretation proposed by these statutes appears to be that Congress serves as a conscientious guardian of Indian interests.

Viewing the legislature as a market and as a fiduciary, respectively, could hardly provide more different perspectives. As market participants, the tribes are portrayed as self-interested hard-

174 Tee-Hit-Ton Indians, 348 U.S. at 290.

175 See, e.g., Worcester v. Georgia, 31 U.S. (6 Pet.) 515, 551-52 (1832).

176 See, e.g., 25 U.S.C. $\$ 2401(1)$ (1988); 25 U.S.C. \$\$ 3101, 3201(a)(1)(F) (Supp. IV 1992). 
bargainers forcefully engaging in arm's-length transactions with other self-interested hard-bargainers, all of whoin seek to purchase congressional influence by trading pohtical support for votes. As wards of the federal government, however, the tribes need not coinpete with other interests to win Congress' attention and concern. Instead, they are entitled to rely upon the good faith and undivided loyalty of a Congress dedicated to the care of its charges. As the Supreme Court, quoting Judge Benjamin N. Cardozo, explained im an Indian law case: " Many forms of conduct permissible in a workaday world for those acting at arm's length, are forbidden to those bound by fiduciary ties. A trustee is held to soinething stricter than the morals of the market place." "177

In sum, public choice theory may offer an important new perspective on statutory imterpretation for most areas of the law, but it is not appropriate to extend that perspective to federal Indian law. The best defense that can be made for legislative markets is that they maximize citizen preferences, despite glarmg dysfunctions. Congress' original assumption of power over the tribes was itself illegitimate in inarket terms, however, because it rested largely on conquest-a method that ignores the preferences of the conquered. Moreover, even if operating perfectly, the public choice model cannot recognize the tribes' preference to stay out of the market altogether.

\section{Interpretive Communities}

Another group of theorists attempts to ground the legitimacy of statutory imterpretation in the concept of an interpretive cominunity. The genesis of these theories seems clear: as it becaine cominonplace in the late twentieth century to accept that words could have different meanings for different people, it becaine harder to defend the judges-as-passive-agents view of interpretation. If objective nueaning was impossible to derive, all judicial opinions were tainted, for not only inconipetent or rogue judges supply meaning to statutes; all judges do so, whether they want to or not. Yet with the demise of an "objectivist" view of language, how

177 Seminole Nation v. United States, 316 U.S. 286, 297 n.12 (1942) (quoting Meinhard v. Salmon, 164 N.E. 545, 546 (N.Y. 1928)). 
could judges defend themselves against the charge that they were behaving undeinocratically by interpreting statutes subjectively?

The idea of the interpretive community took some of the stimg out of this charge. Agreeing that words never have inherent mean$\mathrm{mg}$, these theorists suggest that terms can nonetheless have meanmg within an mterpretive community that agrees on a method of construction, the usage of terms, and fundamental value commitments. While readers in that community may still disagree over how to interpret particular texts, such disagreement will always be cabined by the community's imphicit understandings. Longing for a self-executing, contextless, "objective" view of meaning is therefore senseless; meaning within a community is all that we could ever hope for.

Significantly, judges construing statutes in this manner are not simply rogue actors imposing their own worldview on the polity. They are, rather, members of the interpretive community, and so they share in that community's legitimacy. These theories thus shift focus from the legitimacy of Congress to that of courts, and from consent of the governed to the existence of commumity as the basis of legitimacy. To illustrate, textuahisn and public choice theory both assume that Congress' legitimacy derives from its role as the citizens' representative body. They then urge courts intelligently to follow Congress' imstructions. By contrast, the judge-centered theories seek to demonstrate that even if the judge does supply meaning to the text, she does so on behalf of the interpretive community, so there is no countermajoritarian problent. Her legitimacy is the community's legitimacy. The two rise and fall together.

Different commentators have proposed various communities of meaming. Some of these communities may include individual Indians in their capacity as United States citizens, but none includes tribal Indians qua tribal Indians. Accordingly, whatever their legitimacy over other populations, these communities do not supply a legitimate interpretive strategy for federal statutes regulatnig tribal affairs. To illustrate this claim, I will focus on the two most influential theories of interpretive community-the community of princi- 
ple proposed by Ronald Dworkin and the professional community proposed by Philip Frickey. ${ }^{178}$

\section{Dworkin and Integrity}

In Law's Empire, Ronald Dworkin argues that law is an interpretive practice aninuated by imtegrity. To proniote integrity, judges must interpret the law as a body of principle written by a smgle author, so that it is as internally consistent and as normatively justifiable as possible. ${ }^{179}$ To reach that conclusion, Dworkin wends a lengthy path through the thickets of jurisprudence and political theory. $\mathrm{He}$ is quite self-conscious about the theory of legitinuation that grounds his theory of interpretation.

Dworkin begins by offering an abstract definition of "the poimt of law": it insists that the power of government "not be used or withheld . . . except as licensed or required by individual rights and responsibilities flowing from past pohitical decisions about when collective force is justified." 180 All theories of law must therefore explam how and why law generally justifies the exercise of coercive power. ${ }^{181}$ Dworkm beheves that social contract/consent-based theories do not offer an adequate justification because nuost citizens did not historically consent to the contract's terms. ${ }^{182}$ But, he argues, a political society that enbraces integrity-Dworkin calls such societies "true communities" - can legitinately require obedience and "deploy a monopoly of coercive force."183

Such communities, Dworkin maintams, create obligations even without conscious consent. ${ }^{184}$ Social practice "attaches [special responsibilities] to membership in some ... group, like the respon-

178 I focus on Dworkin's work because of the tremendous notice that it has received and on Frickey's work both because of its significance and because of its attention to Indian law in particular. Other theorists of the interpretive community have also received widespread and deserved notice. See Eskridge, supra note 128; Stanley Fish, Is There a Text in This Class? (1980); Owen M. Fiss, Objectivity and Interpretation, 34 Stan. L. Rev. 739 (1982); David C. Hoy, Interpreting the Law: Hermeneutical and Poststructuralist Perspectives, 58 S. Cal. L. Rev. 135 (1985); Popkin, supra note 1.

179 See Dworkin, supra note 4, at 225.

180 Id. at 93.

181 Id. at 190.

$182 \mathrm{Id}$. at $192-95$.

183 Id. at 188.

184 Id. at 206-07. States Dworkin, "the right of a political commumity to treat its members as having obligations in virtue of collective community decisions .... is to be 
sibilities of family or friends or neighbors."185 Community members thus recognize reciprocal obligations toward one another. These obligations are special (i.e., they run only to otlier members of the community), personal (i.e., they run from each member to every other member), pervasive (i.e., they involve a general concern for the welfare of each member), and egalitarian (i.e., the concern is equal for all members). ${ }^{186}$ Importantly, Dworkin does not rely on "an abstract and timeless political morahty"187 in tracing the basis of law to true commumities. ${ }^{188}$ Instead, lie offers strictly an interpretive claim about "our" social practice: In fact, "we"the interpretive community addressed by Law's Empire-recognize the claims of sucl commumities, despite the absence of consent. As a result, Dworkin's argument by its own terms can justify the force of law only 1) within a true community, 2) whose members believe (as Dworkin believes "we" do) that community can justify the force of law. ${ }^{189}$

Families are the most common example of a true community, but Dworkin believes that polities can create reciprocal obligations as well. Usually, those espousing an interpretive scheme based on true communities have assumed that such communities must be small in order to allow a sense of personal concern to develop between members. Dworkin argues, however, that the members of a true legal commumity need not feel real psychological concern for one anotlier. Rather, commumity can be "an interpretive property of the group's practices of asserting and acknowledging responsibilities - these must be practices that people with the riglit level of concern would adopt."190 Accordimgly, for true legal and political commumity to exist, citizens and expositors of the law need engage only in "as if" interpretation: they will understand the law as if the members in fact knew and loved one another. Correspondingly, the citizens themselves must "accept that tlreir fates are linked in

found not in the hard terrain of contracts or duties of justice or obligations of fair play that might hold among strangers ...." Id. at 206.

185 Id. at 196.

186 Id. at $196-200$.

187 Id. at 216.

188 Dworkin states: "[Q]uestions of justice and fairness are regarded as questions of what would be fair or just within a particular political group." Id. at 208.

189 Id. at 206-08, 216.

190 Id. at 201. 
the following strong way: they accept that they are governed by common principles, not just by rules hammered out in political coinpromise."191

In such "true" communities, legislatures must act according to an ideal of legislative integrity. At the nrost general level, that ideal requires legislatures to inake "the total set of laws morally coherent," 192 to ensure that "the public standards of the community be both made and seen, as far as this is possible, to express a single, coherent schente of justice and fairness in the right relation."193 This ideal flows from the idea of a "true" community itself: such communities are yoked together by a concern to he according to shared ideals, not raw pohtical compromises. ${ }^{194}$

Statutes therefore inust be generally consistent with one another in their concerns, goals, and ideals, and they may never be truly arbitrary. Legislatures may, however, consider both policy and principles in the developinent of statutes, and imtegrity requires less formal consistency of the former than of the latter. In particular, primciple addresses the developinent and formulation of rights, and in this endeavor the requirenents of integrity are strict indeed. Once a legislature has accepted a particular primciple, it may not waver in its observance: "Integrity fixes its gaze on these matters of primciple: government must speak with one voice about what these rights are and so not deny then to anyone at any time."195

In matters of pohcy where individual rights are not involved, however, the legislature has considerably greater flexibility. The legislature nuay nuake nuany decisions that favor one group and hurt others so as to promote the general good of all. As to these pohicy matters, integrity "does not require any simple form of consistency."196 It does not require "consistency within pohicies; it does not require that particular programs treat everyone the same way." "197 It is enough that the program promote the general interest. Thus, for example, the legislature could pay wheat farmers to

191 Id. at 211.

192 Id. at 176.

193 Id. at 219.

$194 \mathrm{Id}$. at 211.

195 Id. at 223.

196 Id. at 221.

197 Id. at 223. 
grow wheat without paying other grain farmers to grow their crops, even if those crops were in short supply, because no one has a right to such payments. ${ }^{198}$

Integrity places only one important constraint on matters of policy: it requires that legislatures adopt soine particular model of equal concern for all citizens and then adhere to it under all circumstances, including pohicy decisions, and for all persons. Legislators have some discretion about which conception of equal concern to adopt, but once they have settled on one, they inay not wander. ${ }^{199}$ In applying that model of equal concern, however, the legislature may take a "long view"; they need only ensure that "government pursue general strategies that proinote the overall good as defined roughly and statistically to inatch what equal concern requires according to the conception in play."200 In matters of pohicy, unlike principle, integrity does not insist upon rigorous consistency "case by case, decision by decision."201 The mutual concern necessary for a true commumity requires only that in matters of policy, the legislature bear the good of each in mind through "general strategies and rough statistical tests."202

That model of pohitical society directly grounds Dworkin's theory of interpretation. The interpretive technique he posits distinguishes between constitutional law and common law on the one liand, and statutory law on the other. When interpreting common law and constitutional law, judges inust adhere strictly to matters of principle in a two-step process. First, the judge must seek to make her interpretation "fit" the relevant body of legal materials. Legal materials, liowever, are often vague and somewhat contradictory, so that a number of interpretations might satisfy this threshhold requirement of fit. In choosing among these interpretations, the judge must then "justify" the law, or seek to make the law "the best it can be" by offering a rendition of the law that best justifies it in hight of her own conception of the pohtical virtues of justice,

\footnotetext{
198 Id. at $221-22$.

199 Id. at $223,310-12$.

200 Id. at 222.

201 Id. at 223.

202 Id.
} 
fairness, and due process. ${ }^{203}$ The interpretation of law is thus not only descriptive but normative as well. ${ }^{204}$

Both of these steps, fit and justification, derive froin the ideal of an associative community that embraces integrity. To satisfy the requirement of fit, an interpretation inust offer a decision that is consistent in principle with large areas of the law, which are also conceived as consistent in principle. "Fit" is thus all about internal coherence. The second stage, justification, less obviously grows out of the ideal of integrity. As Dworkin acknowledges, justification initially evokes notions of natural law rather than internal coherence. $^{205}$ Yet Dworkin explains that in practice the justification requirement is also rooted in the ideal of fraternal community:

We accept integrity as a political ideal because we want to treat our political community as one of principle, and the citizens of a community of principle aim not simply at common principles, as if uniformity were all they wanted, but the best common principles pohitics can find.... [I]ntegrity makes no sense except among people who want justice and fairness as well. ${ }^{206}$

Thus, both stages of interpretation are based on a notion of commumity.

When interpreting statutes, as opposed to constitutional or coinmon law, Dworkin advises courts to use a shightly different techinque. The fundainental two-step procedure is the saine: the judge's interpretation must both fit the relevant legal inaterial and offer the inost attractive rendition of it. Yet the nature of the legal material is different, requiring a change in the considerations appropriate to the task. Textual integrity-congruence with the statute's "plain words"-contributes to the parameters of acceptable "fit."207 Moreover, because legislatures may consider pohicy, judges inust consider policy as well as primciple in developimg the best possible interpretation at both the fit and justification stages. $^{208}$ Finally, evidence of legislative intent-such as legislative history-is relevant for two reasons. First, in constructing a justifi-

\footnotetext{
203 Id. at 229.

204 Id. at 227-32.

205 Id. at $260-63$.

206 Id. at 263.

207 Id. at 338.

208 Id. at 338-39.
} 
able interpretation, the judge will consult the value of political fairness, which requires that a decision that does not "unjustly favor[] some people at the expense of others ... be governed by the will of the people."209 Because legislators will be "sensitive to general public opinion," legislative history, debates, and the like will ordinarily serve as "good evidence of public opinion across the community as a whole."210 Second, because the community is one of principle, judges slould construe legislative history as explaming how the statute "flow[s] from the community's present commitment to a background scheine of political morality."211 Respect for legislative history thus confirms and expresses the community's commitnent to principle.

Thus, fronı beginning to end, Dworkm's proposed interpretive technique relies on the notion of true communities for its legitimacy, and accordingly his proposal lias natural boundaries. First, his argument that law is an interpretive practice ammated by integrity is itself interpretive: lhe seeks to divine "our" social practice and cast it $\mathrm{n}_{1}$ its best light. "We" believe that law is imterpretive and that true community can ground the obligation of law. A community of principle, states Dworkin, provides the best defense of political legitinuacy because

[i]t assimilates political obligations to the general class of associative obligations and supports them in that way. This defense is possible in such a community because a general commitment to integrity expresses a concern by each for all that is sufficiently special, personal, pervasive, and egalitarian to ground communal obligations according to standards for communal obligation we elsewhere accept. ${ }^{212}$

Accordingly, the obligation of law is limited to tliose who participate in these social practices.

Second, even among those who share these practices, "[i]ntegrity lolds within political communities, not among them, so any opmion we liave about the scope of the requirement of coherence makes assumptions about the size and character of these commum-

209 Id. at 341.

210 Id.; see id. at 340-43.

211 Id. at 345-46.

212 Id. at 216. 
ties."213 There are thus two critical questions for Indian law: first, whether tribal Indians participate in the social practices that validate the general argument (i.e., the understanding of law as an interpretive practice rooted in true communities); and second, whether they are in a "true" commumity of principle with the other persons represented in the federal government. For Dworkin's theory to be applicable to Indian law, both questions must be answered in the affirmative.

It is, however, somewhat difficult to know how to go about answering those questions im a Dworkinian way. I will focus lere on the second question because I think that the answer is somewhat easier: tribal Indians are not in a true community of principle with other United States citizens. Dworkin never explains how one divines a true community's boundaries, but his work offers only two real possibilities: the definition of boundaries could be a product of interpretation or premterpretation. In the premterpretive period, "the rules and standards taken to provide the tentative content of the practice are identified."214 In the field of literature, Dworkm suggests, the preinterpretive stage could be compared to "the stage at which the text of Moby-Dick is identified and distmguished from ... other novels." 215 Thus, preinterpretation is what makes interpretation possible, providing the necessary backdrop for the latter to have meaning. In contrast, at the interpretive stage, "the interpreter settles on some general justification for the main elements of the practice identified at the preinterpretive stage," explaining "why a practice of that general shape is worth pursuing, if it is." 216 As Dworkin explains, for interpretation to go forward, there must be a "very great [preinterpretive] degree of consensus" about the "tentative content of the practice" that is to be interpreted. ${ }^{217}$ Indeed, he suggests: "[P]erhaps an interpretive commumity is usefully defined as requiring consensus at this stage."218

\footnotetext{
213 Id. at $185-86$.

214 Id. at 65-66.

215 Id. at 66.

216 Id.

217 Id. at 65-66.

218 Id. at 66.
} 
At points, Dworkin suggests that like the interpretive commuinty, a "true" community must exist at the preinterpretive stage. ${ }^{219}$ He explains that integrity inust make "assuniptions" (presuniably different from interpretations) about the size of the local "true" community. ${ }^{220}$ Like the boundaries of the interpretive community, the boundaries of the "true" community must obtain consensually and without controversy.

If I have interpreted Dworkin's work accurately, then his technique is not appropriate for federal Indian law. Indians and nonIndians, professional law expositors and laypersons alike, profoundly disagree about whether tribal Indians are in a "true" cominunity with non-Indians. The enterprise thus breaks down before it even begins. ${ }^{221}$

Perhaps, however, Dworkin beheves that the boundaries of the local "true" community should be an interpretive issue, so that "we" should look at "our" practice to determine its parameters. I can find no direct evidence that Dworkin in fact embraces this view. At one point he explains that the states comprising our federal union constitute different "true" communities for certain purposes, so that integrity does not hold across them. ${ }^{222}$ He then adds, however, that integrity makes demands on the Supreine Court's federalism doctrine, presuniably because the federal union is also a "true" community for certain purposes, among them the "division of power between the national and the inore local levels." 223 It is thus possible for true communities to exist at different levels, local and central, and the division of authority among these true commu-

219 A true community is presumably one variety of interpretive community, characterized by a high degree of integrity.

220 See Dworkin, supra note 4, at 185-86.

221 For just one example of the different perspectives in this area, consider the colloquy between Robert Laurence and Robert A. Williams, Jr., both of whom are basically sympathetic to tribal concerns. See Williams, Algebra, supra note 10; Robert Laurence, Learning to Live with the Plenary Power of Congress over the Indian Nations: An Essay in Reaction to Professor Williains' Algebra, 30 Ariz. L. Rev. 413 (1988) [hereinafter Laurence, Learning to Live]; Robert A. Williams, Jr., Learning Not to Live with Eurocentric Myopia: A Reply to Professor Laurence's Learning to Live with the Plenary Power of Congress over the Indian Nations, 30 Ariz. L. Rev. 439 (1988); Robert Laurence, On Eurocentric Myopia, The Designated Hitter Rule and "The Actual State of Things," 30 Ariz. L. Rev. 459 (1988).

222 Dworkin, supra note 4, at 186.

223 Id. 
nities nuay be an interpretive (not preinterpretive) question vested in one of these true communities. But the status of the states and the federal government as true commumities-as opposed to the division of power between them-would still appear to be "preniterpretive" assumptions. ${ }^{224}$

For the sake of argument, however, I will assume that Dworkin beheves that the boundaries of a "true" community should be an niterpretive rather than a preinterpretive question, because the conclusion is the same regardless: our social practice suggests that the tribes are not a part of the same commumity of principle. Again, the Court has repeatedly explamed that Indians are a "different people"; government-to-government treaties between the tribes and the federal government are still the law of the land; all three branches of government have spoken of the need for tribal self-determination; and federal statutes recognize the tribal right to self-government. ${ }^{225}$

Two features of Indian law, on the other hand, suggest that the tribes are a part of the true federal community: the Supreme Court's assertion that Congress holds plenary power over the tribes, and Congress' practice of legislating for the tribes. One might thus interpret Indian law, at first glance, in the following way: like states, tribes constitute their own small communities of principle for many purposes, but they are also yoked into a larger federal community of primciple that, among other thimgs, decides how power is to be allocated between the two.

That interpretation, however, would be shortsighted because unlike states, tribes are pre- and extraconstitutional bodies. In his discussion of federalism, Dworkin maintams that the demands of integrity do not hold across states for many purposes, but integrity does denand that states respect the guaranties of individual autonoiny protected by the Constitution because it is that docuinent that fundainentally estabhishes the federal community of principle. For a state or a tribe to be outside the sphere of the Constitution, then,

224 Similarly, the Supreme Court's competence to divide power between state and federal levels would itself appear to be a "preinterpretive" assumption. The basis of that assumption seems clear: by virtually universal consensus, the interpretive community acknowledges (these days) that the Coustitution creates a community of laws and gives to the Court the authority to articulate the demands of federalism.

225 See supra notes 37,39 and accompanying text. 
is to be outside the federal community, ${ }^{226}$ and the tribes are outside both.

As the Supreme Court has recognized, tribal power existed before the Constitution, and the Constitution in no way limits itany more than it limits the authority of the government of Canada. ${ }^{227}$ Although Congress extended some of the protections safeguarded by the Bill of Rights to the tribes in the Indian Civil Rights Act of 1968 ("ICRA"), 228 it dehiberately omitted some provisions. $^{229}$ In addition, the courts have concluded that the provisions extended to the tribes do not impose precisely the same rights and restrictions as their parents in the federal Bill of Rights itself. ${ }^{230}$ Fimally, the ICRA creates only statutory, not constitutional rights; Congress can alter these rights at any time.

In short, Indian law contains contradictory elements: the doctrine of plenary power and Congress' practice of legislating for the Indians suggest that tribes are within the federal community of principle, but much of the substance of federal Indian law suggests the opposite. Admittedly, Dworkin acknowledges that within a body of material contradictions sonietimes occur. In such cases, Dworkin states, interpreters have no choice but to suppress the most discordant eleinents in order to render the remaining nıaterial consistent in principle. ${ }^{231}$ In the case of Indian law, plenary power appears to be the inost discordant element. As discussed above, the Court has not yet offered a basis consistent in principle with the rest of American law justifying the plenary power doctrine. In

226 See Dworkin, supra note 4, at 186.

227 See Talton v. Mayes, 163 U.S. 376, 384 (1896) (stating that "the powers of local self government enjoyed by the Cherokee nation existed prior to the Constitution").

228 Pub. L. No. 90-284, 80 Stat. 77 (codified as amended at 25 U.S.C. $\S \S 1301-1303$ (1988 \& Supp. IV 1992)).

229 See Santa Clara Pueblo v. Martinez, 436 U.S. 49, 62-63 (1978) (noting that $§ 1302$ "selectively incorporated and in sone instances modified the safeguards of the Bill of Rights to fit the unique political, cultural, and economic needs of tribal governments").

230 See Toin v. Sutton, 533 F.2d 1101, 1104 n.5 (9th Cir. 1976) (noting that the terms "due process" and "equal protection" are "not always given the same ineaming [in the Indian Bill of Rights] as they have come to represent under the United States Constitution"); cf. Smith v. Confederated Tribes of the Warm Springs Reservation, 783 F.2d 1409, 1412 (9th Cir. 1986) (noting that tribal courts may adopt procedures different froin federal courts and asserting that "[f]ederal courts nust avoid undue or intrusive interference in reviewing Tribal Court procedures").

231 See Dworkin, supra note 4, at 230-32. 
Johnson v. M'Intosh, ${ }^{232}$ Chief Justice Marshall did not even try to offer a principled explanation, grounding his view in the realities of power. ${ }^{233}$ Today, the Court describes the plenary power as a creation of the Constitution but has not explained low that view is consistent with the Constitution's dedication to social contractarianism or community self-determination. ${ }^{234}$

As a result, whether "true" community lias a preinterpretive or interpretive status, no such commumity embraces both tribes and non-Indians. The fundamental primciples governing within tribes inay be profoundly different froin those governing elsewhere in the United States. As a result, "true" commuinty and its integrity cannot ground a tribal obhgation to obey the law of a different colninunity of principle. Thus, the Court cannot rely on integrity to provide a foundation for interpreting federal Indian statutes. The whole Dworkinian apparatus is simply inapposite-even when taken on its own terms-to the special status of the tribes.

\section{Frickey and Practical Reason}

In significant measure, William Eskridge, Daniel Farber, and Philip Frickey may be responsible for the renewed scliolarly interest in statutory interpretation. Their work is rich, inultiplex, and rewarding, drawing on inany schools of thought, includimg Gadainerian hermeneutics, ${ }^{235}$ public choice theory, ${ }^{236}$ and modified legal process values. ${ }^{237}$ They reject foundationahist interpretation-the idea that any single factor, sucli as legislative intent or predictability-should control interpretation. Instead, they einphasize the importance of contextual judgment, asserting that each judicial controversy involves a unique combination of factors and considerations. ${ }^{238}$ As a result, any characterization of their work risks oversinplification. Indeed, their technique bears proof

23221 U.S. (8 Wheat.) 543 (1823).

233 See supra text accompanying note 19.

234 See Cotton Petroleum Corp. v. New Mexico, 490 U.S. 163, 192 (1989); United States v. Wheeler, 435 U.S. 313,323 (1978).

235 See Eskridge, supra note 128; Eskridge \& Frickey, supra note 32, at 345-46.

236 See Farber \& Frickey, supra note 11, at 425-37; Eskridge, supra note 146, at 277-79.

237 See Eskridge, supra note 1, at 684-90; William N. Eskridge, Jr., Dynamic Statutory Interpretation, 135 U. Pa. L. Rev. 1479, 1482-97 (1987).

238 See Eskridge \& Frickey, supra note 32, at 321-24; Frickey, supra note 6, at 1137-42; Farber \& Frickey, supra note 11, at $452-69$. 
more in the domg than in the telling: their articles typically devote more attention to applying their method to individual cases by way of example than to comprehensively describing the method itself. ${ }^{239}$

Recently, Professor Frickey has argued that this eclectic approach should be applied to federal Indian statutes. ${ }^{240}$ The only full-length apphication of a context-based theory to federal Indian law, this significant work exhibits all the richness and subtlety of Professor Frickey's other scholarship. Ultimately, however, it too founders, even when taken on its own terms, because it attempts to apply a technique developed for another context to this most anomolous field. In particular, Frickey recommends that courts rely upon practical reason-a tool that, as Frickey describes it, has meaning only within a particular tradition, in this case the Western legal tradition-to interpret federal Indian statutes, rules that govern members of an entirely different tradition. ${ }^{241}$

Frickey begins by reviewing recent Supreme Court cases addressing Indian law issues. He suggests that given the tradition of plenary power, one would expect legislative imtent to play an important part in the Court's interpretation of Indian statutes. ${ }^{242}$ Yet that expectation is unfulfilled, for as Frickey powerfully demonstrates, legislative intent has played a relatively mimor role in the Court's analysis. ${ }^{243}$ Instead, four factors dommate the Court's inquiry: a judicial tradition of protecting Indian rights, as revealed in the canons of construction; a behef in dynamic interpretation, which keeps old statutes in tune with current values; a concern for judicial administrability of standards; and some devotion to tribal sovereignty and individual civil rights. ${ }^{244}$ Present to varying

239 For example, Frickey explains that "[t]he very antiformalism" of his method "makes it impossible to break it down into discrete elements and summarize precisely how it operates." See Frickey, supra note 6, at 1209.

240 See id. at 1142 (contending that "the problems of federal Indian law are best understood and analyzed through a contextually enriched framework built on the traditions established by Chief Justice Marshall").

241 Id. at 1208 (noting that "[f]or American judges and attorneys, many . . . preunderstandings consist of values shared in the American legal interpretive community-what might be called that community's web of beliefs").

242 Id. at $1140-41$.

243 Id. at $1142-74$.

244 Id. at $1174-1200$. 
degrees in different cases, these four factors are soinetimes in tension. Moreover, because the Court's use of these factors in deciding Indian law cases does not "suggest any presumptive hierarchy," it is impossible to arrive at a model specifying how a court is to proceed should these values conflict. ${ }^{245}$

Recognizing that because of this conflict Indian law cases "seein too normatively diverse and too fact-bound to accommodate even soine simple model of legal inquiry," 246 Frickey urges the courts to move "away from a general theory of federal Indian law" and turn instead towards contextualized decisionmaking. ${ }^{247}$ Specifically, he encourages judges to engage in practical reasoining, a form of inquiry that consults all the standard sources of statutory authority, including legislative history, text, the statute's evolution over time, and its coherence with "the broader public law." 248 Inevitably, the judge will approach these materials from her own perspective, which includes the preunderstandings shared in the American legal community's systein of values. The judge inust keep an open mind, however, and stand ready to reevaluate her own preconceptions and interpretations in hight of the evidence adduced froin the sources of nreaning. ${ }^{249}$

Practical reasoning does not entail an ad hoc or randoin selection of values. The tradition of federal Indian law, especially as articulated in its paradign cases, can help guide judges in reconciling values that diverge when applied in concrete circumstances. In addition, while judging always nivolves some creativity, the counmunity's "web of behiefs," explored through dialogue, can show some interpretations to be nore persuasive than others. ${ }^{250}$ In this model, to criticize an interpretation is not to assert that "the Court was wrong in some absolute sense, but that the Court failed to exercise practical reasoning and did not reach the interpretation that a full consideration of the problen should suggest to American-trained judges."251 Moreover, Frickey would not reject legisla-

\footnotetext{
245 Id. at 1201-03.

246 Id. at 1203.

247 Id. at 1204.

248 Id. at 1208.

249 Id.

250 Id. at 1217.

251 Id. at 1209.
} 
tive intent as a source of meaning, because "[1]egislative expectations have a normative salience in a deinocracy." "252 But he would regard it as simply one source of meaning, not as the lodestar for all interpretation. ${ }^{253}$

A striking feature of this otherwise rich and inclusive interpretive method is the relative absence of any inention of Indians. Throughout, the technique rehes on the values held by mainstreain culture to gauge acceptability. Thus, although Frickey speaks broadly of "us" and "our values," "we" are limited to members of the American legal community. As a result, the judge will inevitably approach the legal materials before her froin her own perspective, one steeped in Western legal thought and tradition. Although Frickey would have the judge revise her preunderstandings in hight of the treaty or statute under consideration, those texts and their context are strictly non-Indian legal products - statutory language, legislative history, etc. ${ }^{254}$ Such conventional inaterials are unlikely to communicate a tribal perspective. ${ }^{255}$ Most significantly, Frickey's ultimate guide to interpretation-a dialogue exploring the Nation's fundamental values-will occur within a non-Indian professional legal culture. ${ }^{256}$ Frickey's practical reason thus rehes upon a community dialogue, but not that of the tribal community; it would instead be the community of "American-tramed judges" and lawyers who would conduct this debate. ${ }^{257}$ Finally, Frickey accepts without quibble the idea that congressional will should have "normative sahence" in the interpretation of Indian statutes

252 Id. at 1210.

253 According to Frickey, legislative intent cannot serve as the foundation for interpretation because it lacks the necessary objectivity and predictability. Id. at 1211 . And it should not serve as the foundation for interpretation because reliance on some simple notion of legislative intent could lead to absurd, harsh, or impractical outcomes. Id.

254 Id. at 1208.

255 Frickey does emphasize that context matters, and he suggests that part of the context that should matter to "us" is tribal sovereignty and reservation life. Id. at 1220 . According to Frickey, however, that context is relevant only because "we" hold tribal sovereignty as a value; the key to interpretation is thus always congruence with "our" tradition.

256 Frickey takes the position that Indians should have the opportumity to be more active participants in the dialogue, to offer their "perspective." Id. at 1230 n.435. Because the dialogue concerns the legal community's web of beliefs, not the tribes', however, Indians may offer "their" perspective only as it pertaims to "our" valnes.

257 Id. at 1209. 
because of the demands of democracy. ${ }^{258}$ Unfortunately, he fails to recognize that democracy is not a simple concept, that it usually involves some notion of meamingful self-determination, and that for the tribes subjection to the will of the dominant culture may not be consistent with self-determination.

So agam the question fairly presents itself: where did "we" get the right to impose our values on "them"? It is important to note that Frickey's own framework suggests this question; it is not imposed by an ahen perspective. Throughout, his anticolomalist mclinations are clear. He exphicitly offers practical reason as a method by which "to face the concrete consequences of colonization im a modern society." $259 \mathrm{He}$ censures the "largely unilateral colomalism" of Johnson v. M'Intosh. ${ }^{260} \mathrm{He}$ criticizes "foundationalist conceptualism" - $\mathrm{m}$ his view, the traditional method of Indian law interpretation-for failing effectively to protect tribal sovereignty. ${ }^{261}$ Furtliermore, he especially cominends an article by Frank Pominersheim ${ }^{262}$ arguing that Indians wish to remain a "people apart."263 Strikimgly, however, he does so in the course of a discussion explaiming "wliy members of [the American legal interpretive community] sliould care about the tribal context and why we should avoid undermining it when we promote otlier values."264 Frickey never considers this jarring discordance-that the conditions of "tlieir" existence as a separate people will be judged by whether those conditions are acceptable to "our" web of behefs. Indeed, after denouncing colomahism, Frickey essentially recommends a colomalist style of interpretation.

Given Frickey's niterpretive method, it is not difficult to determine the origin of his discomfort with colomalism. "Our" web of beliefs includes a devotion to self-determination and an aversion to colonialism. On the other liand, the tradition of Indian law mcludes the doctrine of plenary power, but again courts lave defended this doctrine primarily as a brute fact rooted in armed

\footnotetext{
258 Id. at 1210.

259 Id. at 1208 .

260 Id. at 1227.

261 Id. at 1206.

262 See Pommersheim, supra note 71, at 249.

263 See Frickey, supra note 6, at 1220.

264 Id.
} 
might, not as a considered conclusion articulately and persuasively justified. As a result, pursued to the bottom, Frickey's own general method should reject Frickey's approach to Indian law im particular; even if we consult our "web of behefs," that consent-based, pro-self-determination web cannot explam why its principles should govern the tribes. ${ }^{265}$

That problem is inherent in Frickey's defense of practical reason. The key advantage of practical reason-indeed, almost the definition of practical reason-is that it is nonfoundationalist. Refusing to sinplify, it considers all inportant factors in context. Thus, Frickey writes: "[P]ractical reasoning assumes that the world of facts and law is too unruly, and our values too complex and divisive, to allow foundational theory to control when it matters most-when it leads to a result that strikes judges as sinnly unacceptable in context."266 Thus, Frickey recommends practical reason chiefly because it allows "our" values to be fully and sensitively explored. That recommendation assumes, however, that "our" values should govern. For most areas of the law, that assumption may be unproblematic, but Indian law is another matter. In some ways, practical reason resembles Dworkm's integrity, if less propositional and more reahstic in its view of judicial capacity, by calling on the judge to make his interpretation resonate with commumity conviction. Unlike Dworkin, however, Frickey does not notice the miphicit limitation on his method: a communty-based technique properly reaches only as far as the commumity itself.

Frickey is by no means insensible of this difficulty. Indeed, he strnggles vahantly to assuage such worries, but his efforts are ultimately unavailing because he cannot transcend the limits of his own method. Repeatedly, he stresses that the judge must approach

265 At one time, the tradition did include a justification-the rights of a superior culture to conquer lesser cultures-but that notion seems to have dropped out of the tradition. The "web of behefs" today might offer one argument: it might reject the idea that Indians are a separate people any longer, so that majoritarian dennocracy works as well for them as for any other group of citizens. Frickey does not pursue this argument because he believes that the Indians are a people apart. See id. It is possible that the tradition does contain an articulate defense of congressional power over the tribes that $I$ have not found, but until Frickey proffers that defense, his argument is at best incoinplete. Importantly, for this defense to succeed froin Frickey's point of view, it must both concede that the tribes are a people apart but also maintain that Congress has legitimate authority over them.

266 Id. at 1210. 
the legal tradition to be construed with an open mind ready to revise his preunderstandings, and that the tradition of Indian law has the capacity for self-criticisin. ${ }^{267}$ Yet there are significant reasons to doubt whether that self-criticism will be sufficiently penetrating. If recent history is any guide, the Court has becoine less sensitive to Indian interests, not more so. ${ }^{268}$ As Robert Williains lias compellingly documented, the discourses of Indian law have been marked by racism and violence from the beginning, attitudes that can be found in today's legal writings as well. ${ }^{269}$

Frickey acknowledges this dark tradition, ${ }^{270}$ but lie argues that there is another side, exemplified by John Marslall's work. Marslall, according to Frickey, recognized that in "his role as Chief Justice of the higliest court of a colonizing government" lie could not deny the rights of conquest. ${ }^{271}$ On the otler hand, he also created the pro-Indian canons of interpretation and sought vainly to protect tribal riglits of self-government under the federal mantle. ${ }^{272}$

Altliough Frickey praises Marshall's approacl, he nonetlieless fails to take seriously the origin of Marsliall's discomfort witl colomalisin. ${ }^{273}$ Marshall believed that conquest violated "natural justice" - that most foundationalist of abstract concepts. Specifically, Marshall felt pulled to recognize the tribes' rights to sovereignty and self-government because of a higher obligation that took precedence over his local culture's understanding of the riglits of conquest. Practical reason, however, leads to a rejection of Marshall's higlier law; it confirms judges in the idea that the test of any interpretation is its congruence witl the "best" ideology of the dominant culture. ${ }^{274}$

267 Id. at $1222-30$ (demonstrating this principle through analysis of Chief Justice Marshall's evolving approach to Indian law).

268 Frickey himself recognizes one instance of this increasing insensitivity. See id. at 1237; see also Cotton Petroleum Corp. v. New Mexico, 490 U.S. 163 (1988) (permitting a state tax on non-Indian lessees of an Indian tribe on Indian Country, even though the result is double taxation by the tribe and the state, causing economic disadvantage to the tribe as lessor).

269 See Williams, supra note 33; Williams, Algebra, supra note 10.

270 See Frickey, supra note 6, at 1230.

271 Id. at 1224.

272 Id. at 1223-29.

273 See supra text accompanying notes 17-22.

274 Frickey does recognize Marshall's use of "higher-law norms," and he describes that use with apparent approval. See Frickey, supra note 6, at 1229. I assume that he regards 
Frickey recognizes that danger as well. He acknowledges that the "community's web of beliefs could . . . produce their share of hidebound or narrow-minded outcomes." 275 Nevertheless, he urges us to be optimistic:

Like foundational theory, practical reason requires its users to make a leap of faith. Practical reason makes some charitable assumptions about the competency of advocates, who must frame the context and the dialogue. So, too, judges must not only be open-minded, but they must also have the capacity and energy to engage in the complex, hard work of critical imterpretation. ${ }^{276}$

Unfortunately, that "leap of faith," however wise in other areas of the law, is peculiarly unwarranted in the context of Indian affairs. As Frickey concedes, judges are almost totally ignorant of the conditions of reservation life. ${ }^{277}$ Perhaps most find even the basic analytical categories of Indian law strange and anomolous. Indeed, if the tribes have made strides in the twentieth century, it may in part be because the "conceptual foundationalists" simplified and clarified the field, focusing on a few key ideas, such as tribal sovereignty and the fiduciary obligation. Moreover, in recent decades, minorities have been understandably wary of schools of thought that urge judges to eschew abstract concepts-such as "rights"-for flexible decisionmaking. ${ }^{278}$

Most fundamentally, lowever, judges lave never regarded tribal Indians accurately because the dominant culture has defined Indians according to its own internal agenda. From the Noble Red Man to the Brutal Savage to the modern Environmental Steward, Indians lave occupied in non-Indian minds a symbolic role that has had hittle to do with their actual condition and much to do with the

those norms as part of the Western legal comnunity's web of beliefs prevailing at that time; Marshall's invocation of thein is therefore an exercise of practical reason. That description, however, fails to recognize that for Marshall higher law was not sinply part of "our web of beliefs," but was instead the command of Heaven. Marshall transcended his time not because he was "an American-trained judge"-indeed most American-trained judges might well have disagreed with him-but because he felt pulled by the Voice of Right.

275 Id. at 1219.

276 Id.

277 Id. at $1219-20$.

278 See, e.g., Robert A. Willianis, Jr., Taking Rights Aggressively: The Perils and Promise of Critical Legal Theory for Peoples of Color, 5 Law \& Ineq. J. 103, 120-27 (1987). 
present self-doubt of non-Indians. ${ }^{279}$ Indeed, as recently as 1980 , Justice William $\mathrm{H}$. Rehnquist notoriously described Plams Indians thus: "The Plains Indians seldom practiced agriculture or other primitive arts, but they were fine physical specimens . ... They lived only for the day, recognized no rights of property, robbed or killed anyone if they thought they could get away with it, inflicted cruelty without a qualm, and endured torture without flinching." "280

Frickey has one last defense: the plea of inevitability. Even if practical reason inay perpetuate the effects of colonization, it nonetheless produces the best results that judges can hope to secure, given that they are ineluctably caught in their own culture. ${ }^{281}$ That hermeneutical insight has been the subject of enormous recent controversy, and in the space of this Article I can only register my basic agreennent. But even if judges are defined by their culture, that culture may contain the seeds of its own repudiation or inodification, which inay serve as the fundainental interpretive guide for a decolonized Indian law.

In particular our web of beliefs imcludes convictions that would suggest that the dominant culture's hegenony over the tribes is illegitimate. In assuming that practical reason should govern the interpretation of Indian law, Frickey fails to consider that practical reason would recommend displacing practical reason-or at least "our" practical reason operating within "our" set of values. Despite recognizing that the legal tradition includes colomal and anticolomal elements and recommending that the latter prevail over the former, ${ }^{282}$ he does not follow his own counsel. Instead of decolonizing the interpretation of federal Indian statutes, he keeps that practice firmly within the bounds of "our" professional dialogue. In recommending Marshall as a model, Frickey might liave

279 See generally Robert F. Berkhofer, Jr., The White Man's Indian: Images of the American Indian from Columbus to the Present (1978); Drinnon, supra note 34; Pearce, supra note 34.

280 Umited States v. Sioux Nation of Indians, 448 U.S. 371, $436-37$ (1980) (Rehnquist, J., dissenting) (quoting Samuel E. Morison, The Oxford History of the American People 53940 (1965)). Rehnquist closed this opimion thus: "[I]n a court opimion, as a historical and not a legal matter, both settler and Indian are entitled to the benefit of the Biblical adjuration: 'Judge not, that ye be not judged." Id.

281 See Frickey, supra note 6, at 1226-30.

282 Id. at 1230. 
followed in his footsteps one pace further; Marshall may have accepted that he could not ultimately deny Congress' power, but he also never lost the disturbing suspicion that Congress-and by implication the legal community, our web of beliefs, and our dialogue about traditional values-liad no autliority to govern the tribes. ${ }^{283}$

\section{Analogical Consent}

In a recent, insiglitful article, Ricliard Collins argues that the Court interprets and slould interpret Indian statutes and treaties as if the tribes liad consented to them. ${ }^{284}$ Collins first explains that the Constitution rests on the proposition that the only legitimate basis of government is the consent of the governed. ${ }^{285} \mathrm{He}$ next notes that Indians "are now citizens and entitled to vote during adulthood, whicl counts as the foundation of consent under the principles of liberal democracy embodied in the Constitution."286 As a result, Collins maintaims, courts must assume the Congress does in fact liave constitutional power over the Indians, because courts are "creatures of the Constitution."287

283 As this Article went to press, Professor Frickey published Philip P. Frickey, Marshalling Past and Present: Colonialisnı, Constitutionalisn1, and Interpretation in Federal Indian Law, 107 Harv. L. Rev. 381 (1993), whicl expanded and refined but did not significantly revise the view espoused in his earlier work. Again, Frickey calls for adherence to "Marsliall's legacy"-a piece of the Western legal tradition-without ever exanining wly it is legitinuate to apply a non-Indian interpretive tradition to statutes governing Indians. Id. at $427-28,438-40$. Similarly, while urging courts to protect tribal sovereignty as part of Marslall's legacy, Frickey also concedes-indeed argues-that another part of Marshall's legacy is colonialisn. Id. at 394-95, 404-05. But without a convincing normative defense of colonialism, courts cannot rely on it to undergird an interpretive strategy-even though they niay liave to accept it as a fact of life, see supra text accompanying notes 29-31. Thus, in this article, as in his earlier work, Frickey takes as his starting point the conviction that "our" tradition should control the interpretation of Indian statutes. He never considers whether the anticolonial elements of our tradition might repudiate the idea that it should control statutes inade to govern another people.

284 Collins, supra note 43 , at 375 .

285 Id. at 370.

286 Id. at 371.

287 Id. Collins may overstate his point here. Liberal denıcracy does not rest siniply on enfranchisenient, but on consent to the system of enfranclisenient to be enployed. Nonetheless, the Court has read the Constitution's text and history to give Congress jurisdiction over the tribes irrespective of consent. Thus, as "creatures of the Constitution," perliaps the Court must recognize congressional power over the tribes, but 
Collins does not contend that the Indians consented to the Constitution's founding. Indeed, the Constitution of 1787 largely conceived of the Indian tribes as "outside of the body pohtic it established."288 Instead, tribes entered the federal union largely by way of collective consent, as expressed in treaties, rather than by obtaining individual consent, as expressed in the vote. ${ }^{289}$ Indeed, Congress has often respected the requirement of tribal consent. Early in its history, it negotiated treaties with the tribes, and even after 1871, when it stopped making treaties with the Indians, it continued to deal with the tribes by securing treaty-like agreements later enacted as statutes. ${ }^{290}$ Similarly, more modern statutes, such as the Indian Reorganization Act and Public Law No. 280, ${ }^{291}$ as modified by the Indian Civil Rights Act, apply to each tribe only if the tribe consents. ${ }^{292}$

Unfortunately, Congress' concern for tribal consent has been "uneven and imperfect." with the Umited States, and the Umited States secured many treaties by coercion. In such cases, Collins seems to suggest, the basis for Congress' authority is at best unclear: "Whatever the abstract constitutional theory, the devastating power of a distant legislature, not beholden to Indian votes or to Indian consent in any other way, is a jarring dissonance in a democratic polity."294

Yet, "[w]hen Congress has acted with doubtful Indian consent or contrary to it," Collins notes, the courts have responded by adopting certam "ameliorative policies."295 For example, in the early years of contact, the still-powerful Indian tribes retamed considerable bargaining power, and the resultant treaties typically protected Indian autonomy. In the years simce, the Court has imterpreted subsequent agreements in accord with these early "peace treaties"

it has done so out of deference to the brute authority of the Constitution, not because of the principles of liberal democracy.

288 Id. at 367.

289 Id. at $366,372$.

290 Id. at 372.

291 Act of Aug. 15, 1953, ch. 505, 67 Stat. 588 (codified as amended in scattered sections of 18,28 U.S.C.).

292 Collins, supra note 43 , at 373 .

293 Id.

294 Id. at 374.

295 Id. 
as broadly preserving tribal government, even though the later treaties less clearly protected the tribes. ${ }^{296}$ Similarly, the Court has adopted pro-Indian canons of construction to be used in interpreting Indian statutes and treaties. The most important of these canons specifies that the Court will interpret legal documents in the light inost favorable to the Indians or as the Indians would have understood them "in hight of language and cultural barriers."297 The Court gives these canons meaning by assuming that the best evidence of the Indians' wishes and interests is contained in the same early peace treaties that preserve tribal government. ${ }^{298}$ Collins explaims: "Properly understood, the imphicit judicial inessage to Congress is, you have plenary power to dictate to the Indians, contrary to their consent, but consent is such a vital constitutional principle that we shall require you to exercise that power openly and plainly."299

Collins' thesis thus rests the legitimacy of Congress' jurisdiction on the tribes' actual consent to the social contract. Sometimes the tribes hiterally consented, as they did when agreeing to be bound by peace treaties or the Indian Reorganization Act; at other times the courts impute consent by interpreting unilateral legislation to be consistent with the documents to which the tribes actually consented. $^{300}$ As a descriptive matter, that conclusion seems to me both accurate and illuminating: both Congress and the courts are concerned that Congress' jurisdiction over the tribes may be usurpatory, so they have adopted strategies to soften the harsh reality of conquest. Those strategies, moreover, have succeeded to soine extent.

They are not, however, sufficient to estabhish the legitimacy of Congress' authority over the tribes. Within the liberal democratic framework of analysis endorsed by Collins, the tribes could not have historically consented to a majoritarian scheme of government. For hiberals, the decision to agree to the social contract is

296 Id. at 374-78.

297 Id. at 379.

298 Id. at $379-80$.

299 Id. at 380.

300 Indeed, Collins believes that this scheine provides the best possible protection for tribal autonomy, because a constitutional right to sovereignty would be too vague to be enforced. Id. at 383-84. 
morally binding because it is the act of autonomous, rational actors who recognize their own autonomy and rationality. They enter into the contract to pursue their own good, ceding certain powers to the majoritarian state but reserving other hiberties to themselves. As tribal Indians have seldom-if ever-thought in these liberal terms, they could not have given the necessary liberal consent to the compact.

Collins' two central examples-the peace treaties and the Indian Reorganization Act-well illustrate this point. As Collins argues, many of the early treaties contain a clause in which the tribes concede the superior sovereignty of the United States; by practice, the courts in turn inferred a clause guaranteeing tribal sovereignty under federal supervision. But notice how much is missing from this alleged "social compact": the powers ceded to the federal government are nowhere precisely dehneated, nor is the authority reserved to the tribes or the liberties reserved to individuals described. Indeed, the treaties do not even provide for the enfranchisement of individual Indians.

Moreover, the liberal social contract is a rich and highly culturally specific concept, and it does not translate well across borders. Nimeteenth-century federal officials did not conceive of Indians (unmodified by federal shaping) as liberal selves, ${ }^{301}$ and neither did nineteenth-century Indians. From within a Native American culture espousing an organic connection to other humans, animals, plants, and places, ${ }^{302}$ the liberal social contract must have seemed incomprehensible. ${ }^{303}$ If that description is accurate-if Indians neither appreciated the social contract concept nor understood theinselves to be liberal agents-then they could not have offered the hiberal consent necessary to establish the authority of a hberal government over them.

Collins would perhaps respond that although the tribes might not have understood the social contract's terms nor have conceived of theinselves as liberal agents, they nonetheless did consent in a general way to limited federal sovereignty. Yet general consent to limited sovereignty is of the sort contained in a treaty of alhance,

301 See, e.g., Dippie, supra note 24 , at 79-121.

302 See Barsh, supra note 165, at 187-89.

303 Id. at 193-95. 
not the type of specific and informed consent necessary to bind oneself to a social contract. By giving their general consent, the Indians agreed not to enter the federal union, but to beconie an allied nation-a very different concept. Under the terms of the treaties, individual Indians acquired no civil or political rights, nor were they granted representation in Congress. To construe these treaties as consent to join the federal union is to construe thenr as consent to political slavery. As all good Lockeans beheve, one cannot sell oneself into slavery, because some rights are inahenable. Consent to pohitical disenfranchisenrent cannot ground a governnuent; it cannot be "a fundainental tenet of deinocratic constitutionalisnr." $" 304$

We inay never understand the full historical context of the early treaties, but they cannot be divorced from the pervasive racisin and coloniahisn of the tine. Froin the Indian perspective, the treaties provided an opportunity to placate the invading power by granting it land and pledging inutual support. Afterwards, they hoped to hive their lives inuch as they had before, with some allowance for the nearby presence of American citizens. ${ }^{305}$ On the federal side, no one equated the treaties with social contracts designed to inerge tribal Indians into the American polity. In the view of nost American politicians, tribal Indians were still savages, a separate people hiving on a separate land base unfit to exercise political and civil rights in the fabric of the United States. ${ }^{306}$ Considered in context, then, the treaties never even purported to be the "consent of the governed" to Congress' plenary power. Instead, the tribes specifi-

304 Collins, supra note 43 , at 365 .

305 See Clinton, supra note 10, at 1027-29; cf. Vine Deloria, Jr. \& Clifford Lytle, The Nations Within: The Past and Future of Ainerican Indian Sovereignty 8 (1984) (noting that "[i]n almost every treaty ... the concern of the Indians was the preservation of the people").

306 See Williams, Borders, supra note 10, at 832-41. To the extent that the United States exercised jurisdiction over Native Americans, it treated thein as wards or children rather than citizens. Liberalisın might be able to recognize such an arrangement, but only by incorporating the racist and colorialist assumptions of the nineteenth century. These assumptions are no longer available to us, however, not only because Americans lave largely rejected that ideology in general, but because American Indians are now full citizens, with all of the rights possessed by every other citizen. As Collins would acknowledge, see Colhins, supra note 43, at 374, the legitimacy of Congress' authority over thein cannot be predicated on the idea that they are as babes, devoid of the qualities that make citizens. 
cally consented to a government-to-government relationship, sharply bounded by the terms of the particular treaty itself.

By contrast, the Indian Reorganization Act does contain a liberal consent nechanisin, but for just that reason the IRA is considered by many tribes to be illegitimate. Originally billed as the ultimate concession to tribal self-determination, the IRA lias recently come under attack as imposing a non-Indian notion of self-determination on the tribes. ${ }^{307}$ It provides a inechanisin to allow each tribe to decide whether to accept the IRA and to adopt a constitution; and the constitutions typically provide a meclianisin to allow tribal meinbers to control tribal officials. ${ }^{308}$ But the inechanism by which these decisions are to be made is an election, a reservation-wide contest in which each tribal meniber receives one vote. In contrast, nrany tribes historically conducted their affairs by mechanisms of consensus, decentralization, the preservation of traditional beliefs, and deference to elders or otlier wise persons. ${ }^{309}$

That tension between the IRA and traditional practices is perliaps best and inost famously illustrated by recent developinents in the Hopi Nation. The Hopi, under the guidance and urging of the Bureau of Indian Affairs, did hold an election to adopt the IRA and an IRA constitution. ${ }^{310}$ The election was not without controversy, however, for inany traditional Hopi simply refused to vote because they did not recognize elections as legitimate. ${ }^{311}$ Instead, they preferred to observe the authority of Hopi Way, as interpreted by local kikmongwi on a village level. ${ }^{312}$ To this day, many traditional Hopi regard the tribal council as a tool of the Bureau of Indian Affairs and non-Indian industrial interests. ${ }^{313}$ That cultural division has centered in recent years on the tribal council's decision to allow Peabody Coal to strip mine Black Mesa, an area sacred to traditional Hopi and to Hopi Way. ${ }^{314}$ For these two groups of

307 See Getches \& Wilkinson, supra note 155, at 128-29.

308 See 25 U.S.C. § 478 (Supp. IV 1992); Vine Deloria, Jr. \& Clifford M. Lytle, American Indians, American Justice 14-15 (1983); Edward H. Spicer, Cycles of Conquest 351-52 (1962).

309 See Barsh, supra note 165 , at 185-87, 191-93.

310 See Peter Matthiessen, Indian Country 77 (1984).

311 See id.

312 See id. at $69,71,77-78$.

313 Id. at 77-78, 90-91.

314 See id. at 86-93, 96-99. 
Native Americans-traditional and progressive-the concept of self-determination has markedly different cultural forms and meanings. ${ }^{315}$

By their own terms, then, hberal consent and the social contract have meaning and can justify government authority only within a hberal contractarian society. They are not culturally transparent notions and hence cannot bridge the gulf between hiberal and nonhiberal cultures. ${ }^{316}$ To imterpret statutes as if the tribes had actually consented to them, judges need examples of arrangements to which the tribes did consent, but Indian tribes never did consent to congressional government in the way necessary to justify authority in liberal discourse. Without doubt, in some sense, the tribes agreed to something-but that something was treaty federahism between nations. It is not possible-as Collins would mamtain - to equate that consent to the social contract model commonly taken to underhe American government. In short, then, while Collins' argument powerfully explicates how judges employ the canons of construction and offers an amehorative interpretive technique to help the tribes, it does not offer a satisfying account of the basis of Congress' authority over the tribes. ${ }^{317}$

315 See id. at 101-02.

316 That theoretical difficulty suggests a practical one as well: Collins' approach prevents judges from performing the task assigned them in his schema. The canons that Collins favors require judges to interpret statutes and treaties "in favor of the Indians" or "as the tribes would have understood them." Collims, supra note 43 , at 379 ; see supra text accompanying note 297. But as Dworkin and Frickey might point out, judges find themselves entrapped in context, able to penetrate the cultural boundary between themselves and tribal Indians only with extreme difficulty. They approach texts with their own cultural preunderstandings in mind, and while the text might cause a judge to reassess his preunderstandings, that process can only occur if the judge is open to such reassessment. Collins, however, mstructs judges to read Indian law texts as embodying a liberal framework. As long as they do so, they cannot hope to understand the text from a nonliberal Indian point of view. Judges are thus unable to appreciate that many tribal Indians inhabit a world other than classical liberalisin, and that for them self-determination might mean soinething different than it means to those who are familiar with and knowingly abide by the social contract model.

317 It is possible to recast Collins' argument slightly: instead of actual consent, one might argue that fignral consent legitimates Congress' authority over the tribes. "Consent" in hberal discourse is not a historical occurrence but a moral construct: persons who possess certam qualities would consent to certain propositions; because those persons, with those qualities, are exemplars of character, we should recognize the propriety of those propositions. But that circular argument really does nothing more than endorse the 


\section{A Suggestion}

I have dwelt at length on the inadequacy of conventional theories of interpretation, as applied to Indian law, in order to establish the paranneters of an adequate theory. The options confronting judges are relatively limited. Judges interpret Indian statutes regularly, and so they inust einploy some theory of interpretation; they do not have the privilege of ignoring the problem. Judges cannot rid themselves of this difficulty, moreover, by simply applying interpretive theories appropriate to otler areas of legislation, because those theories rest on assumptions about Congress' authority that are inapposite in the field of Indian affairs. The problem, then, is real, pressing, and not susceptible of easy solution. A new and very different direction is necessary.

In this Part, I propose, in rougli terins, such a direction. Most interpretive theories espoused by judges justify autliority etiologically; power is just if it lias the riglit origin, one arising out of either consent or commumity. As I have souglit to argue, such a theory is unavailable for Indian law because few are prepared to defend the etiology of Congress' power over the tribes. Anotlrer possibility does, however, exist: Congress' Indian statutes might be deemed legitimate not because they liave the riglit origin, but because they are riglit on the merits-substantively rather than etiologically. Defending Congress' sclreme of Indian law on that basis would ground a corresponding interpretive technique: judges should prefer tlie interpretation of Indian statutes that makes theen as close to "right" as possible.

This proposal takes its origin not from theoretical reasoning but from the reality of historical circumstance. Indeed, perhaps no theoretical defense can justify Congress' authority over the tribes; certainly none is easily available today within conventional political discourse. Nonetheless, listory lias put judges in an awkward position, for they must interpret Indian statutes notwitlistanding the paucity of convincing theoretical defenses justifying this practice. In such a situation, they can ouly do the best tliat tliey can do, and a substantive defense of Title 25 may be the best-and perhaps the only-defense available. To elucidate tlrat claim, I begin by elabo-

particular substantive quahities and propositions. Accordingly, we should turn to substance directly, as I do in the next Section, without the intervention of the consent metaphor. 
rating upon the uncomfortable role that history has thrust upon modern federal judges.

\section{A. The Historical Situation}

As inany have observed, Indian law is a product of history. 318 That general observation holds true whether one is interpreting federal statutes or conteinplating issues of substance. To understand how to interpret statutes, judges must understand the basis of Congress' power to make statutes, but today that basis is obscure because of changing convictions over the last hundred years. Over much of its history, the Uinited States generally traced its authority over the tribes to an origin different froin that justifying its authority over non-Indian citizens. Internally, the United States grounded its authority in various concepts of consent and community. Externally, however, the United States premised its right to seize land and jurisdiction from the tribes on a claint of racial and cultural superiority: God or Progress meant for His or Its chosen people to settle this "unpopulated" corner of the Earth by educating, relnoving, or eliminating its savage inhabitants. ${ }^{319}$

In this century, under the force of events, that easy distinction between internal and external discourses has becoine problematic. Americans have generally rejected the racism that justified the old external approach, and concomitantly Indians have beconie partially imternalized. Now enfranchised citizens, they can no longer be regarded as savages to be despoliated or inolded by a beingn White Father in Washington. ${ }^{320}$

Yet the internal justifications camiot take the place of the old external discourses rendered alien by time, for they are inapposite to the tribes' situation. In various ways, these discourses of consent and community all presune political lonıogeneity anıong citizens. Scalia, Easterbrook, and Dworkni, for instance, implicitly posit a political order in which citizens relate to their government in fundanientally the same way-by being voters in a majoritarian democracy, consuners in a legislative nrarket, or participants in a

318 See Charles F. Wilkinson, American Indians, Time, and the Law: Native Societies in a Modern Constitutional Democracy 29-31 (1987); Getches \& Wilkinson, supra note 155, at 33.

319 See supra text accompanying notes $34-35$.

320 See supra text accompanying note 286 . 
community of principle. Although Frickey and Collins recognize that the tribes stand in a position different fron non-Indian citizens, at the same time they seek to justify federal Indian law by scheines that suppose full imternality-the legal community's web of beliefs and consent to the social contract.

In truth, we seen to have no clear discourse to consider this difficult post-colomial situation. ${ }^{321}$ Other nations have dealt with the residue of empire by retreating; the old European powers, for example, relinquished their African colonies, allowing the aboriginal populations to reclaim their full independence. ${ }^{322}$ Congress is unlikely to pursue that path by according the tribes international recognition, even if such recognition were limited to their present reduced land base. In the view of many, inyriad sinall nations within the boundaries of the United States would prove disruptive to the "national interest." Instead, Congress has chosen to pursue a policy similar in broad outline to that adopted by other "settler states," allowing aboriginal populations to enjoy a right to limited self-government on a separate land base but denying them full international recognition. ${ }^{323}$

The fact that Congress will not eschew plenary power and recognize the tribes as nations does not mean that it should not, and tribal advocates and scholars have argued for precisely that course ${ }^{324}$ In the abstract, a wunder-judge could premise her interpretive strategy on just that conclusion by deciding that as a moral agent, she must deny Congress' riglt to legislate for the Indians, whatever the consequences. In the real world, however, it is highly unlikely that any judge will plot that course..$^{325}$ While it is right to

321 For consideration and description of this post-colonial situation, see Ball, supra note 9, at 11-20; Clinton, supra note 44, at 860-66; Frickey, supra note 6, at 1204-05.

322 See, e.g., Basil Davidson, Let Freedom Come: Africa in Modern History 199-282 (1978).

323 See B.A. Keon-Cohen, Native Justice in Australia, Canada, and the U.S.A.: A Comparative Analysis, 7 Monash U. L. Rev. 250, 264-65 (1981).

324 See supra text accoinpanying note 28 .

325 Even if a justice privately believed that Congress has no legitimate authority over the tribes, she would face huge imstitutional obstacles im publicly so asserting. As John Marshall might suggest, to deny Congress' power over the tribes would be to deny the United States' legitimate existence on the North American continent; as officers of the United States government, judges are unlikely to issue such a denial. Moreover, the Constitution does in fact explicitly grant Congress some power over the Indian tribes in the Indian Commerce Clause. See U.S. Const. art I, § 8, cl. 3 ("Congress shall have Power ... 
rail against such complacency, it is also important to consider how such unrevolutionary judges, who accept the fact of congressional power over the tribes, can set about interpreting congressional statutes governing Indian tribes.

These judges confront the following unenviable task: they must concede the power of Congress to pass statutes, but to imterpret those statutes they must discover a theory of post-colomal power over aboriginal populations-a theory that the world has not yet developed with any precision or consensus. It is important to recognize just how profound that problem is. History has deposited these judges in a new position with no analytical framework to understand that position. The einergence of Fourth World nations and the deimse of colonial ideology but not of the colonial form leaves these judges seeking to develop a justification for a situation whose original justification has become untenable. With the external discourse gone, one carmot simply apply the internal discourse to the tribes-unless one is also prepared to force the tribes into complete imternality.

\section{B. A Post-Colonial Reconstruction}

Accordingly, Indian law nust write on a relatively blank slate in creating the structures of a new post-colonial world, and I offer the following suggestion with some tentativeness. Most American political thought addresses the legitimacy of sovereignty as a procedural or historical question; it considers how a government legitiinately canie by its power, as by the consent of the people or the assent of an affective community. Much analysis of Indian law, by contrast, imphicitly considers the legitimacy of Congress' authority over the tribes not as a procedural matter but as a substantive one.

Most Indian law commentary today addresses not the general right of Congress to legislate for the tribes but the substantive merits of particular pieces of legislation. Whatever its defects, plenary power is a reahty, and so inost writers argue not that Congress may

To regulate Commerce with foreigu Nations, and among the several States, and with the Indian Tribes . . . ."). While the Court might interpret that power narrowly, it faces a virtually unbroken chain of precedent construing it in very broad terms. See supra text accompanying notes 6-30. In any event, even if the Court were to construe Congress' power over the tribes more narrowly, it would still face the interpretive problem of discerning the basis of that power within its new and more restrictive scope. 
not pass laws about the tribes at all but that it should pass good laws. ${ }^{326}$ Many of these commentators, I suspect, are actually quite dubious about the legitimacy of Congress' power but are prepared arguendo to accept it in evaluating individual statutes. That view could give rise to an interpretive technique along the following lines: even if Congress has no right to pass laws for the Indians, as long as it passes the right laws, then everything comes out right in the end. A usurper, however illegitimate, nay prove himself by his acts, and the modern Congress, enbarassed by conquest, may want to do right by its charges. Accordingly, courts should interpret congressional statutes to be "good" or "right" or "the best possible" for the tribes. The whole enterprise nay be a pact with the devil, but good terms are better than bad, even in a pact with the devil.

Such a view may be common even among those who are not professional observers of Indian law. Many law students are eager to proffer the following narrative argument: right or wrong, the conquest happened, and it is far too late to return to the precontact status quo ante. ${ }^{327}$ Now, they posit, we should inake the best of it; we should treat the tribes well in recognition of the evils done to them but entertain no fantasies of rejecting Congress' authority. ${ }^{328}$

326 See, e.g., Carole E. Goldberg, Public Law 280: The Limits of State Jurisdiction over Reservation Indians, 22 UCLA L. Rev. 535 (1975); Manuel P. Guerrero, Indian Child Welfare Act of 1978: A Response to the Threat to Indian Culture Caused by Foster and Adoptive Placements of Indian Children, 7 Am. Indian L. Rev. 51 (1979); Arthur Lazarus, Jr. \& W. Richard West, Jr., The Alaska Native Claims Settlement Act: A Flawed Victory, 40 Law \& Contemp. Probs. 132 (1976); Damel M. Rosenfelt, Toward a More Coherent Policy for Funding Indian Education, 40 Law \& Contemp. Probs. 190 (1976); Charles F. Wilkinson \& Eric R. Biggs, The Evolution of the Termination Policy, $5 \mathrm{Am}$. Indian L. Rev. 139, 165-66 (1977); Robert A. Williams, Jr., Small Steps on the Long Road to SelfSufficiency for Indian Nations: The Indian Tribal Governmental Tax Status Act of 1982, 22 Harv. J. on Legis. 335, 383-97 (1985).

327 "Too late" seems to draw on a number of values. It is too late in the sense that Marshall thought it too late: if one is a product of a given culture, one cannot deny the right of that culture to exist. It is too late in the sense that Indians are ineradicably changed by contact. It is also too late in the sense that non-Indians will not, perhaps could not, and in any event should not return to their home territories because the resultant suffering would dwarf any gains.

328 Oddly enough, even the nineteenth century Supreme Court offered a similar view in describing the origin of the fiduciary obligation. According to the Court, because the United States has systematically reduced the Indians to a state of dependency, it subsequently chose to recognize an obligation to take care of them. See United States v. Kagama, 118 U.S. 375, 384 (1886). 
Similarly, the few Indian law commentators who defend congressional power do so on the pragmatic ground that Congress has exercised its power relatively wisely and well. ${ }^{329}$

Indeed, although no court has said as much, the canons of construction may have come to play such an ameliorative role. In developing tools for imterpreting Indian statutes, the courts liave assiduously avoided imvestigating the legitimacy of Congress' authority. Instead, they have offered a substantive guide, mstructimg courts to interpret statutes and treaties so as to benefit the Indians to the greatest extent possible. If courts liave doubts about the procedural legitimacy of Congress' authority, the canons may reassure them that by upliolding a law of dubious procedural legitimacy they are at least not rendering a result of questionable substantive merit. In that sense, the canons already contam the seeds of a reconstructed theory of interpretation. If every theory of interpretation is a theory of legitimation, then the canons implicitly offer the following justification for Title 25: Congress may or may not have the right to legislate for the tribes, but tlie legislation tliat it has made is substantively right-or as right as the courts can make it. ${ }^{330}$

Althougln this approach may allow us to evade investigating the basis of Congress' autliority, it poses anotlier problem: finding a norm or a practice that defines "substantive correctness" (or trutl or beauty or morality or goodness or justice) for the field of Indian law. In part, the problem arises because Indian law occurs at a juncture between two cultures: it regulates the interaction between the tribes and the Umited States government. Thus, Indian law constitutes, in the postmodern sense, an intertext between two peoples, eacli with its own mode of understanding the world. ${ }^{331}$ Tradi-

329 See Frickey, supra note 6, at 1238-39 \& n.470; Laurence, Learning to Live, supra note 221, at 424-28; cf. Collins, supra note 43, at 381-86; id. at 386 (arguing that the "gauntlet of federal legislative and administrative processes and of judicial review ... effectively defangs the specter of plenary federal power").

330 As I elaborate later, the Court has never explicitly offered this argument to defend its use of the canons. See infra text accoinpanying notes 357-59. Nonetheless, the canons nay already serve this psychological role for judges: if they doubt the procedural legitinacy of Congress' authority, they may nonetheless seek substantively to do right by the tribes.

331 See William E. Connolly, IdentitylDifference: Democratic Negotiations of Political Paradox 36-45 (1991). 
tionally, Western liberal culture has used two meclramisms to attempt to bridge sucli a cliasm.

First, it lias attempted to link the two cultures by seeking some archimedean point not derived from principles internal to eitler community, a meta-norin that transcends the two cultures and that is not rooted in any particular society. Because this norm is "objective," so the argument goes, it can command allegiance from a variety of communities, all of which recognize that the norm is neither "biased" nor contingent. In the late twentietl century, lowever, transcendent moral or cognitive knowledge seems increasingly implausible. Knowledge nuevitably is culture-specific; indeed, it is only the structure of a given culture that makes truth claims possible. All of life is interpretation, but only a preexisting sclieme of thouglit niakes interpretation possible. Cultures and the trutlis they contain can evolve, but even as they do so, the evolving principles of normative reahty remain internal to the culture undergoing such clrange. Cogmition, analysis, and reflection can occur only against the background of an intellectual practice or tradition; thinking caimot occur in a vacuum. Moreover, we are born nito a community, and we internalize tliat community's practices and ideologies without any awareness of doing so. Although we may alter our relationship to that culture, drawing ideas from other communities witl which we have had contact, we can never escape the fact that our imitial and familiar preunderstandings liave been situated in some culture or conibination of cultures. ${ }^{332}$

Awareness that understanding is socially contructed has not escaped those who write in the field of statutory interpretation. One of the great contributions of Dworkin, Eskridge, Farber, and Frickey has been to emphasize that an "objective" perch for interpreters is unavailable. Judges inevitably approacl a text with cultural preunderstandings. They are connected to the text by a tradition of understandings that stretclies froin the writers of the text, through earlier interpreters of the text, to the present day. Admittedly, the text itself or the context of its application may cause judges to reconsider their preunderstandings or to offer a

332 See, e.g., Richard J. Bernstein, Beyond Objectivism and Relativism: Science, Hermeneutics, and Praxis 93-108 (1983); Symposium on the Renaissance of Pragmatism in American Legal Thought, 63 S. Cal. L. Rev. 1569 (1990). 
new interpretation, thus bequeathing a new tradition to later interpreters. Nonetheless, the whole enterprise occurs within a tradition that is a human construct taking hold in a particular place at a particular time. Judges cannot have access to "objective" interpretations of statutes nor to the "objective" values that would provide a transculturally "best" view of Indian law. ${ }^{333}$

The other traditional Western response to intertextuahty has been to inpose our domestic norms on other cultures, not because those norms are acultural but because our culture is better. For hundreds of years, such a notion legitimated the discourses of conquest, repression, and assimilation. Without doubt, soine still adhere to such an idea. Such simple cultural imperiahsm is increasingly unavailable, however, to justify state action for two reasons. First, it still implies that some acultural norm is available to determine which cultures are better than others. Second, as I have sought to argue above, such a view is inconsistent with both the inodern materials of Indian law and modern theories of pohtical legitimacy. Virtually every presidential administration and every Congress of the last several decades has affirmed its belief in tribal self-determination. ${ }^{334}$ Moreover, the leading conventional theories of doinestic governmental authority are not inherently imperiahist. Rather, they explain the nature of "our" legislature's authority over "us"-citizens who have knowingly and voluntarily consented to the social contract, or citizens who are members of a rich coinmuirity of principle. ${ }^{335}$ They do not seek to justify imperial ventures on the ground that our culture is superior.

That anti-imperiahist norm is itself culturally situated; it is the product of a hberal democratic culture now embarassed at the

333 Again, the Indian Reorganization Act offers an example of the difficulty of creating a neutral, context-free meta-norm. When it was first passed, many viewed the IRA as a tremendous gesture towards tribal autonoiny-a "neutral" framework that would allow tribes to chart their own courses. In this view, the IRA was a device that transcended the two cultures by allowing each to develop independently. In practice, however, selfgoverninent is itself a culturally contingent concept, and the conception of self-government einbedded in the IRA was that of liberal democracy. Far from being "neutral" or "objective" or culturally transcendent, the IRA was the product of a distinctively nonIndian view of the way that pohties ought to be ordered. See supra text accoinpanying notes $307-15$.

334 See supra text accompanying note 225.

335 See supra Parts I.B, II. 
excesses and failures of past imperialist ventures. As applied to the tribes, it was a lesson liard learned after many failed attempts at assimilation and mucli self-examination during the revisiomist 1960 s and afterwards. But even if it is only "our" norm, that norm still imstructs us that it is mappropriate simply to impose our values on other cultures absent some special justification such as aggression or massive atrocities. In short, neitlier cultural imperialism nor acultural norms offer a promismg imterpretive strategy. To develop such a technique, it is necessary to look elsewhere.

\section{A Text Between the Texts}

In recent decades, imternational law activists, tribal leaders, and Indian law cominentators have developed a theory of a "substantively correct" Indian law system that centers on tribal sovereignty. It is a theory developed in part out of the norms of Western culture but also out of the stories of aboriginal peoples. It is thus a product of both cultures, one might even say a new culture that has evolved at the place where the two cominunities meet. It is a text between the texts that might allow mutual communication. Most importantly, this approacl does not seek to explain the legitimacy of Congress' autliority; at most, it recognizes tliat autliority as an irreversible fact arising out of a bloody past. Instead, it seeks to develop a substantive understanding of low aboriginal peoples can best exist within a nation tliat does not share their culture. Some have attempted to encode tliat view into international law protections, ${ }^{336}$ while others have sought to entrencli it through a constitutional amendment. ${ }^{337}$ Judges, lowever, can employ this theory im a different way-as a guide to interpreting federal Indian statutes. In so actimg, judges would demonstrate respect for both Western culture and tribal culture, help give the canons of construction meaning, and possibly allay the courts' conquerors' anxiety.

I will not attempt to recapitulate a body of work that is ricli and evolving except to sketcli its mam contours. Over a decade ago, Robert Clinton outlined an argument for tribal sovereignty rooted in part in Western values and concerns, among them: the realization that assimilatiomist policies liurt the very people that they are

336 See infra text accompanying notes 343-52.

337 See Barsh \& Henderson, supra note 33, at 279-82. 
designed to help; ${ }^{338}$ the notion that our ethic of promise-keeping requires the Nation to respect treaties guaranteeing tribal self-government; ${ }^{339}$ the idea that our respect for property rights coinpels the Nation to recognize the connection between tribal landholding and the exercise of sovereignty; ${ }^{340}$ the fact that reservation policy allows individual Indians to choose freely annong a variety of cultural options; ${ }^{341}$ and the perception that tribal cultures contribute to the nation's diversity, offering a fund of values and ideas to the population as a whole. ${ }^{342}$

In the international sphere, after years of testimony from aboriginal leaders, a United Nations Working Group recently proposed a Draft Universal Declaration on Rights of Indigenous Peoples. ${ }^{343}$ If accepted, the Draft would guarantee to aboriginal populations a variety of rights related to tribal self-government: a collective right to existence as a distinct people, ${ }^{344}$ a right to inhabit traditional territories, ${ }^{345}$ a right to enjoy their traditional neans of subsistence and other economic activities, ${ }^{346}$ a right to bring treaty claims before international mechanisins, ${ }^{347}$ a right to cultural autonomy, ${ }^{348}$ and a right to "have their specific character duly reflected in the legal system and $\mathrm{m}$ pohtical and socio-econormic institutions, mcluding im particular proper regard to and recogintion of mdigenous laws and customs." ${ }^{349}$ Although those participating in the Working Group often appeal to imternational norms and princi-

338 See Clinton, supra note 10 , at 1027.

339 Id. at 1032.

340 Id. at $1042-44$.

341 Id. at $1050-51$.

342 Id. at 1063.

343 Discrimination Against Indigenous Peoples: First Revised Text of the Draft Universal Declaration of Rights of Indigenous Peoples, U.N. ESCOR, Comm'n on Hum. Rts., Sub-Comm'n on Prevention of Discrimination and Protection of Minorities, 41st Sess., Provisional Agenda Item 13, U.N. Doc. E/CN.4/Sub.2/1989/33 (1989) (prepared by the Chairman-Rapporteur of the Working Group on Indigenous Populations, Mrs. EricaIrene Daes, pursuant to Sub-Commission resolution 1988118) [hereinafter Draft Universal Declaration]; Williams, supra note 70, at 665-66.

344 Draft Universal Declaration, supra note 343 , at 6 , II 3.

345 Id. at 6-7, IT $12-17$.

346 Id. at $7, \mathbb{1} 18$.

347 Id. at $8, \mathfrak{g} 28$.

348 Id. at 6 , III 4-7; see Williams, supra note 70, at 694-95.

349 Draft Universal Declaration, supra note 343, at 7, 21; Williams, supra note 70, at 694. 
ples, ${ }^{350}$ the group has been careful not to impose undue screening procedures, such as strict evidentiary or standing requirements, so as to allow indigenous peoples to tell their own stories in their own way. ${ }^{351}$ One observer has concluded: "[T]hrough the power of their stories, indigenous peoples have begun to transform legal thought and doctrime about the rights that inatter to them under international law." 352

The contemporary defense of tribal sovereignty inust stand or fall on its own merits, and I cannot further that defense as such in the compass of this Article. Rather, iny argument is that it is the right kind of theory to guide judges as they struggle to interpret federal Indian statutes. Instead of likeming Congress' authority over the Indians to its autliority over otler citizens, international theories defending self-determination take seriously botli the tribes' special status and the uncomfortable situation that history and evolving norms have thrust on countries with aboriginal populations today. Accepting that retreat to a precontact status quo ante is not possible, these theories recognize that nations with aboriginal populations may have legitimate interests in asserting some jurisdiction. ${ }^{353}$ Accordingly, none of these theories seeks to deny all congressional autliority over the tribes. Those championing tribal self-government also maintain, lowever, that because the tribes' cultural distinctiveness deserves similar respect, merger into a larger majoritarian system must be avoided. ${ }^{354}$

350 See Williams, supra note 70, at 678 .

351 Id. at $679-82$.

352 Id. at 682.

353 The Draft Universal Declaration, for example, does not recognize a right of secession. See Williams, supra note 70, at 695 .

354 In recommending a substantive approach to interpreting federal Indian statutes, I do not mean to engage in that evil denounced by Professor Frickey-"foundationalist conceptualism." The concepts associated with tribal sovereignty do not have any inherent meaning or foundational status; they exist in a culture, are defined by that culture, and will change with that culture. They recommend themselves to judges because judges are a part of that culture. They are concepts, but as Frickey would admit, no analysis of any kind can dispense with concepts. While the proponents of tribal sovereignty seek to limit the range of concepts that judges may legitimately consult in interpreting Indian statutes, Frickey would also seek to limit tlie range in eschewing the colonialist tradition in American Indian law. See supra text acconipanying notes 259-64. Finally, taking a conceptual approach to Indian law does not deny the significance of context in the adjudication of disputes on Indian Country. Instead, the concepts associated with tribal sovereignty simply help to identify important considerations that tend to legitimate Indian law within extant culture. 
While that claim is perhaps most relevant for Congress, the body charged with formulating Indian policy, it is also relevant to the Court, the branch charged with interpreting such statutes. If Congress' authority has legitimacy in this field, it derives not from democratic procedure but from the substantive validity of the laws themselves. If courts give fealty to Indian statutes, it must be because they are good statutes; as a result, to the extent possible, the courts must interpret them so as to make them substantively sound.

I wish to emphasize how much this proposal is necessarily a makeshift imterpretive system, the product of discordant historical forces. I have assumed that the Court must presume the legitimacy of Congress' power, but I have also argued that no persuasive rationale exists for that legitimacy beyond the substantive merits of individual statutes. The resulting interpretive stance las inevitable himits. The Court inay try-has tried-to interpret Indian statutes in the best light possible; it may even slight the text and the legislative history as significant sources of ineaning. ${ }^{355}$ Because the Court feels that it must acknowledge Congress' power, however, it can ouly take such tactics so far. If Congress makes its meaming plam enough, the Court must recognize statutes that drastically curtail tribal sovereignty. ${ }^{356}$ Such a course may induce considerable intellectual discomfort, for defending a "bad" statute substantively is impossible. Instead, the Court must act as if Congress' authority over the Indians were procedurally legitimate-even though it is not. But that tension is the product of a post-colonial society, an accomodation with a fractured world in which power is a reality and legitimacy a sometimes ephemeral achievement.

For the same reason, this proposed method of interpretation is quite similar to present practice except in the psychological stance that it forces upon a judge. As Professor Frickey has argued, the Court tends to pay only vague attention to legislative will in Indian

As the culture changes in response to sensitivity to context, so might the standards for substantive legitimacy in Indian law affairs.

355 See Frickey, supra note 6, at 1142-74.

356 In such cases, the Court presumably has no choice but to interpret the statute as it would any other statute, by reference to text, history, and the other conventional sources, but also aided to the greatest extent possible by the canons. Id. at $1141 \&$ n.28. 
law cases. ${ }^{357}$ Instead, it primarily considers substantive factors in interpreting statutes, as represented in the canons of construction. Indeed, the canons themselves deinand that the courts interpret statutes in the best interests of the tribes, and the Court has maintained that a substantial part of those interests hes in tribal sovereignty. ${ }^{358}$ On the other hand, the explanation for the use of the canons would be very different. At present, courts never admit that they use the canons as a substitute for democratic legitinacy. Instead, the Court most often justifies its use of the canons by arguing that they help to ascertam legislative intent since Congress itself has assumed a fiduciary obligation toward the tribes. ${ }^{359}$ That defense, of course, does not contest the procedural legitimacy of Congress' authority. If, however, the courts were to acknowledge that the canons are used to make Indian law substantively legitimate because procedural legitimacy is impossible, their practice would likely change. Importantly, the canons would not be optional standards, to be enforced or ignored in individual cases as they lielped to divine congressional intent. Instead, they would claim as important a role as text or legislative history im other imterpretive theories because they are fundamental to the substantive legitimacy of federal Indian law, the only kind of legitimacy possible in this area.

\section{Readers Between the Texts}

The content of Indian law and the process by which it is created are at present in some tension. Although the content may no longer be openly imperialist, our practice of lawmaking and interpretation is. As a substantive matter, tribal self-government is an important feature of Indian law, and it has attracted articulate, sophisticated defenders. As a structural matter, however, the tribes are still at the mercy of Congress and of the typically nonIndian courts who interpret Congress' will. In recognizing tribal self-government, Congress and the executive have conceded that "tlie Indian future [should be] determined by Indian acts and

357 See id. at 1142-74.

358 See id. at 1174-1203.

359 See, e.g., Bryan v. Itasca County, 426 U.S. 373, $392-93$ (1976); Mattz v. Arnett, 412 U.S. 481, 504-05 (1973). 
Indian decisions." 360 To some extent, the political branches have acted on that conviction by passing legislation that promotes tribal self-determination, but all such acts are still a product of congressional discretion. If the Indians' future really should be determined by the Indians, it remains unclear why Congress should continue to claim the jurisdictional right to make the decisions that most significantly affect Indians' lives. At a minimum, one might expect that the tribes should receive some formal decisionmaking authority in Congress over issues that will affect their futures. ${ }^{361}$

Such a reform in legislative procedure does not seem to be im the offing. As I have argued, absent the procedural legitimacy that such reform might provide, the substance of Indian law alone may justify congressional authority-if anything may. Accordingly, judges sloould use a substantive rather than a procedural theory to guide their interpretation of Indian statutes. But that mode of interpretation creates another tension: the structure of interpretation is inconsistent with the substance of the theory used to guide interpretation. Judges-most of whom are non-Indian and all of whom are appomted or elected as a result of majoritarian decisions in the larger population-make critical interpretive decisions for the tribes, but they do so in accord with a substantive theory that emphasizes the importance of the tribes' inaking decisions for themselves.

This tension is especially acute because of the cultural borders that must be crossed in substantively interpreting Indian statutes. The substantive theory of interpretation calls upon judges to promote tribal self-determination to the greatest extent possible, but to do so they must understand the significance and meaning of tribal self-government. Both tribal and Western culture einbraces the concept of self-determination to soine extent, so many judges inay have a technical or propositional grasp of it. The concept can have meaning, however, only as applied in context - that is to say, with some sense of its place on Indian Country. Judges, particularly federal judges, and most especially Supreme Court justices, have hinited exposure to on-reservation conditions and little understanding of the importance of tribalism in the lives of Indian citizens; one

360 Nixon Message, supra note 38, at 1.

361 See Clinton, supra note 70 , at 746. 
can hardly expect them to respond to those conditions with any sensitivity. ${ }^{362}$

In short, a judicial interpretive method that excludes the tribes reflects an imperialist style inconsistent with the anti-imperialist substance of Indian law. A Title 25 that integrated structure and substance would have to allow the tribes some ongoing decisionmaking role in interpretation. As the tribes have rights to make laws for themselves, so they should have rights to interpret the laws made for them.

At least two models are available for consideration. ${ }^{363}$ The first would allow individual tribes to interpret federal statutes for themselves, so as to tailor their application to each reservation. The Indian Civil Rights Act offers an example of how such a system would work. The Act inposes provisions that resemble the Bill of Rights on the tribal governments. ${ }^{364}$ According to the Court's decision in Santa Clara Pueblo v. Martinez ${ }^{365}$ however, an individual may challenge a tribal court's imterpretation of the ICRA in federal court ouly through habeas corpus proceedings. ${ }^{366}$ As a result, all civil cases and inany criminal cases construing the ICRA remain withm the tribal court system. The Supreme Court was candid about its reason for interpreting the ICRA in this mamer: Congress intended the Act to extend American constitutional norms to the tribes, but at the same time did not want those norms sigmificantly to disrupt tribal culture. Denying a cause of action except for habeas writs proved an attractive compromise, as the

362 See Frickey, supra note 6 , at 1219-20. As discussed above, such insensitivity is painfully evident in Yakima Indian Nation. See supra Part II.A.1. While purporting to interpret the statutes at hand in favor of the Indians, Justice Scalia wholly failed to note the devastating effects of the state's foreclosure pohicy. That policy effectively reinitiated the transfer of land out of Indian hands that had been the inost inghtmarish consequence of the Dawes Act and that the IRA had largely been passed to halt. Perhaps inore significantly, under modern case law the geographical scope of tribal sovereignty shrinks with the tribal property base; thus, Justice Scalia's interpretation not only divested the Indians of land, but power. See supra note 104.

363 I recommend these models on the grounds that they will dehver better interpretations of federal Indian law statutes. Professor Clinton has offered convincing arguments on behalf of similar models on other grounds, that as a matter of political morality, tribal courts are due the dignity, power, and independence inherent in these bodies. See Clinton, supra note 44 , at $886-97$.

364 See 25 U.S.C. $\$ \S 1301-1303$ (1988 \& Supp. IV 1992).

365436 U.S. 49 (1978).

366 Id. at $59,70,72$. 
tribal courts could tailor the ICRA to reflect their own tribal context and values without persistent outside judicial influence. ${ }^{367} \mathrm{By}$ contrast, federal courts before Santa Clara Pueblo had held that the ICRA did create a federal cause of action and simply required reviewing courts to be sensitive to the individual tribal context. ${ }^{368}$ Santa Clara Pueblo conteinplates that federal courts cannot adequately perform that task, but tribal courts can and should.

The ICRA allows the tribes to play a role in interpreting the statute in two ways. First, except in habeas corpus cases, the tribe alone interprets the statute's substantive mearing; no federal official has any input. Second, the statute is interpreted on a tribe-bytribe basis, without any nationwide body insisting on uniformity. As a result-although I know of no scholarly study surveying the tribal courts' work on this score-one would anticipate that the ICRA's mearning varies substantially across Indian Country.

When uniformity is of greater concern, however-cases involving issues that cut across reservations and in which the federal government has a direct interest, for example-a second, different model may be appropriate. To preserve both uniformity and tribal self-determination, Congress might create a Court of Indian Statutory Interpretation, staffed by both tribal judges and federal judges. This court would have jurisdiction over all cases that mvolve significant, crosscutting interpretive questions about Indian treaties and statutes. The advantages of such a court would be multiple. Indian law is a highly specialized field that demands indepth knowledge of an anomalous body of legal doctrine and an unfamiliar factual setting - the reservation context. In that sense, a Court of Indian Statutory Interpretation would be analogous to the Tax Court, the Court of Clains, or even the D.C. Circuit-a judicial body expert in an esoteric field. But this court would have another advantage as well: it would be staffed at least in part by Indians, who have certain advantages in interpreting Indian statutes. I have argued that any defense of Congress' scheme of Indian law inust be substantive; it inust depend on the claim that because the laws are beneficent, they deserve allegiance. Interpretive

367 Id. at $62-70$.

368 See Wounded Head v. Tribal Council of the Oglala Sioux Tribe, 507 F.2d 1079 (8th Cir. 1975); McCurdy v. Steele, 506 F.2d 653 (10th Cir. 1974); Conroy v. Frizzell, 429 F. Supp. 918, 925 (D.S.D. 1977). 
expertise in this field must therefore extend not only to the typical judicial skills-reading text and legislative history, creating analogical arguments and the like-but also to divining what is "in the best interests of the Indians." Tribal Indians have an obvious advantage in answering that question. In seeking to staff the Bureau of Indian Affairs with Indians, Congress has already recognized that advantage in the administrative field. ${ }^{369}$ It has not yet extended the same approach, however, to federal courts handling Indian cases. ${ }^{370}$

Such a court might not be without its own legitimacy problems. Many might perceive it as a "political" body created to favor the tribes rather than to interpret the law. Again, however, this law/ pohitics distinction-if tenable anywhere-is out of place in the context of Indian affairs. The distinction rests on the notion that courts should smiply follow Congress' will or abide by the words of the text, rather than import political values into the interpretation process. As I have argued, however, it is entirely unclear that Congress' will should command respect in this field. By contrast, "pohitical values"- the right result-might be the only thing that could legitimate these statutes.

One might, however, raise an objection almost exactly contrary to the pohtical favoritism objection: far from favoring Indians too inuch, membership on such a court might co-opt its Indian ineinbers, subtly convincing them to cooperate with the dommant culture. Without a doubt, such a risk exists; indeed, the Nation's history is replete with similar phenomena. ${ }^{371}$ That risk may, how-

369 See 25 U.S.C. § 472 (1988); Morton v. Mancari, 417 U.S. 535, 541-45 (1974).

370 Staffing a court with members drawn from specific affected groups is not unknown to North America. By statutory requirement, three of the nine judges on the Canadian Supreme Court must be Quebecois, and by convention, three must be from Ontario, two from the Western provinces, and one from the Atlantic provinces. See Peter W. Hogg, Constitutional Law of Canada 168 (2d ed. 1985).

371 For example, the "capture doctrine [in administrative law] posits an agency ultimately dominated by the industry it sets out to regulate." Alfred C. Aman, Jr., Administrative Equity: An Analysis of Exceptions to Admimistrative Rules, 1982 Duke L.J. 277, 326-28; see Marver H. Bernstein, Regulating Business By Independent Commission 270 (1955). But see Richard A. Posner, Theories of Economic Regulation, 5 Bell J. Econ. \& Mgmt. Sci. 335, 342-43 (1974). Similarly, Damiel Patrick Moynihan has observed that the War on Poverty's attempts to involve poor people often co-opted them into fruitless incrementahisn. See Daniel P. Moynihan, Maximum Feasible Misunderstanding: Community Action in the War on Poverty (1969). 
ever, be inevitable whenever two cultures come into contact and inust learn how to communicate. In any "talking place" that sits at a postinodern intertext, the options are inherently limited. First, the cultures may decide not to talk at all and choose to go their separate ways; for better or worse, that course is not a possibility for the tribes as long as congressional plenary power is a reality. The other option is to develop a joint language or pool of values. In so doing, neither culture will be able to inaintain perfect integrity, but adaptation need not entail outright absorption. In any event, it is the best course possible within the constraints imposed by history.

Even under extant law, such as the ICRA, the tribes have soine role in interpreting certain federal statutes, but that role is still exceptional, not yet the rule. The normal practice still is for a nonIndian body to resolve clouded but important issues that will drastically affect the hives of on-reservation Indians. Because we are so used to this practice, it nay not seein to be the relic that it is-an unexammed by-product of nineteenth century colonial attitudes.

\section{CONCLUSION}

We hive among the shards of a violent imperial venture that few can now bring theniselves to defend. Disturbingly, all around us we see the afterproducts of that venture, but few are willing to retreat from them. At the tine of this writing, I live in Indiana, a state named after Indians that are, for the inost part, gone. In the early nineteenth century, Congress forced thein beyond the Mississippi River to inake room for white settlers, and all they left behind are nanies on the map-Kokonio, Tippecanoe, Blackhawk, Anoka, Nappanee. In a sense, that contrast is a metaphor for the anxiety that non-Indian Americans nust face in the late twentieth century. We accept the benefits and powers that conquest has brought without being confident that the conquest was just.

That anxiety should be inore acute for United States government officials. One of the most important legacies of the imperial experience is Congress' plenary power, rooted in a colonial mindset that carries hittle sympathy in the nodern world and caimot offer a conteinporary explanation for Congress' power over the tribes. For that reason, Indian law-in anything like its present incarnationcannot be morally pure. To seek purity in the field by assimilating 
Congress' power over the tribes to its authority over others can succeed only by self-deception. Somehow, members of Congress must make their peace with that legacy, with a power that may now seem an embarassment to those who stop to ponder it.

No less must the courts seek to reconcile power derived from the past with today's moral imperatives when grappling with the meanmg of Congress' assertions of its dubious power. In a morally confusing world, courts sometimes take solace in their own passivity; they proclaim that they only interpret the law, not make it. But hidden behind that claim is an implicit defense of the passive posture: Congress should make the law because Congress is democratically legitimate. Yet for Indian law that defense is at best controversial, and if Congress' democratic legitimacy is in doubt, then so is any interpretive style that relies implicitly on that legitimacy for justification. Ultimately, courts may have to concede Congress' power to legislate for the tribes, but simply acceding to that power helps the courts not at all in constructing an imterpretive strategy.

I lave argued that the best interpretive technique may be one that rests Congress' authority not on its procedural democratic legitimacy but on the substantive defensibility of the laws that it lias produced. This interpretive paradigm embraces that great judicial hobgoblin, "results-oriented decisionmaking," in a fairly extreme way. The judges' task is to interpret Title 25 so as to make it the most substantively legitimate code of Indian law possible. If interpreted in accord with emerging international norms, the most legitimate code would be one that promotes tribal sovereignty. Such overt results-oriented analysis is nothing new to this field, however; the canons of construction already require judges to interpret statutes and treaties in the maimer most favorable to tribal self-government. Moreover, there is good reason to take such an overtly substantive approach to interpretation: in this field, the right result may contribute more to Title 25's legitimacy than does Congress' majoritarian procedure.

Such issues of statutory interpretation will surely become imcreasingly important as the 1990s draw on, and the Reagan/Bush Court continues to rewrite Indian law. Substantial evidence already exists that at least some of the Court's members do not take the canons very seriously, that they reject a substantive 
approach to interpretation in this field, and that they find the tribes' special status disturbingly aberrational. Indeed, some justices seem to retain some of the old imperial mindset, although they inay not be quite prepared overtly to defend it. Apparently disturbed by the idea that tribes have special rights of self-governinent, these justices have begun to interpret federal protections for tribal sovereignty narrowly and to minimize the differences between tribes and other groups. ${ }^{372}$ Increasingly, they have begun to assert that Indian law is simply a product of congressional imtent, like any other area of law. Although they have not defended that interpretive strategy, the implicit justification is not hard to divine: Indians are citizens like all others; they vote and enjoy imdividual rights, and so congressional authority over them is no different from any other exercise of congressional authority over any other citizen. That view doubtless brings comfort and some apparent analytical tidiness, but only at the cost of ignoring history, the political convictions of both the dominant culture and tribal cultures, and the content of Indian law itself.

In interpreting federal Indian statutes, courts must labor in the wilderness. There are no certainties, no easy verities, and no stable platforms of repose. They must accept Congress' power, but they cannot adequately defend it. That situation is the product of historical flux, and further societal evolution inay alter the judicial posture once again. In another hundred years, a new culture of discourse may allow us to glean a legitimate basis for Congress' power over the tribes, or Congress inay retreat from the practice of making statutes for the tribes altogether. For now, courts can only struggle with the discordant consequences of a world fractured by history.

372 For an example of these tendencies, see my discussion of Yakima Indian Nation, supra Part II.A.1; see also Cotton Petroleum Corp. v. New Mexico, 490 U.S. 163 (1989). 
